\title{
Towards a Political Economy of Military Spending
}

by

\author{
Mark Robbins
}

A thesis submitted to the Faculty of Graduate and Postdoctoral Affairs in partial fulfillment of the requirements for the degree of

Master of Arts

in

Political Economy

Carleton University

Ottawa, Ontario

(C) 2015, Mark Robbins 


\begin{abstract}
Although the direct costs of the military are well known, there is regular reference to the 'spin-offs' that supposedly justify military expenditure. Unfortunately, the sheer heterogeneity and complexity of military institutions and political-economic landscapes have consistently eluded an even-keel and scientific analysis of military spinoffs. To pursue this question of military spending's externalities further requires a stronger analytical foundation which clearly situates the military's role within the politicaleconomy.
\end{abstract}

This work thus seeks to navigate a rich ontological landscape across a wide historical spectrum in order to colour the relationship between the military, the state, and society at large. Focusing attention on questions of military investment in human capital, military R\&D, Keynesianism and other tenants of military spending, I posit that, while military spending tends to be less economically productive than comparable spending projects conducted through other means, military spending performs functions indispensable to the political-economic structure of the state. 


\section{Acknowledgements}

I like to thank both Dr. Randall Germain and Dr. Elinor Sloan for their comments and feedback as the work progressed as well as Dr. Norman Hillmer for his insights as a member of the defence committee. I would also like to thank Dr. Randall Germain and Dr. Laura MacDonald for their encouragement and support throughout the pursuit of my Master's studies at Carleton University and the Institute of Political Economy. I would not have gotten this far without them and the confidence they placed in my abilities. Finally, I would like to thank my parents for making this work possible and my fiancé, Rose, for making it bearable. 


\section{Table of Contents}

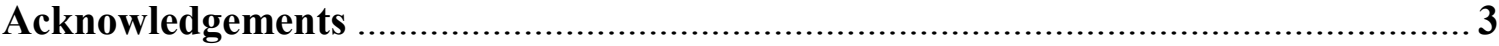

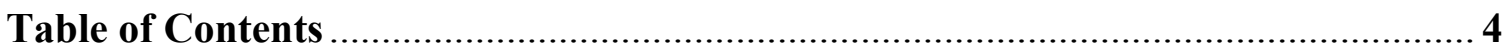

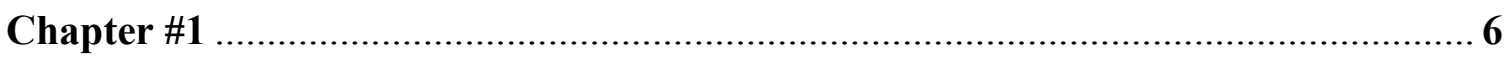

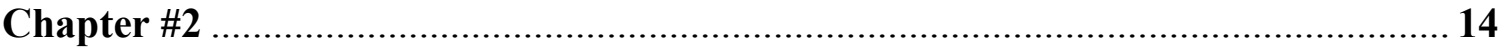

2.1 The Birth of the State and the Liberal Tradition........................................... 15

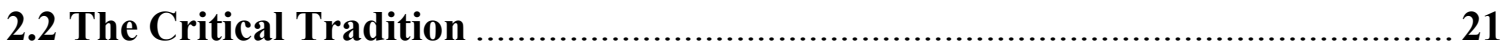

2.3 Embedded Liberalism: A Post-War Synthesis................................................ 27

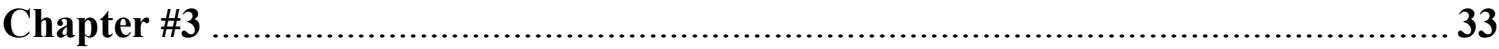

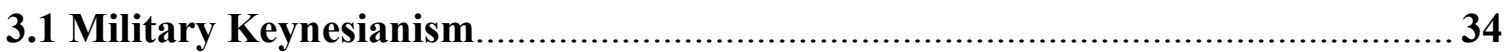

3.2 The Subtle Contours of Military Macroeconomics......................................... 43

3.3 Unproductivity Reconsidered ............................................................... 47

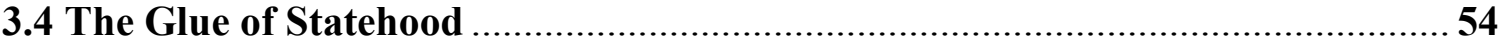

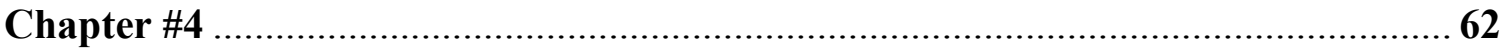

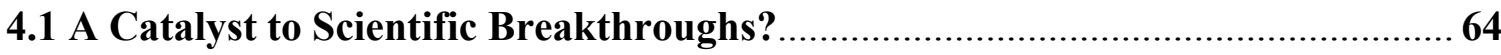

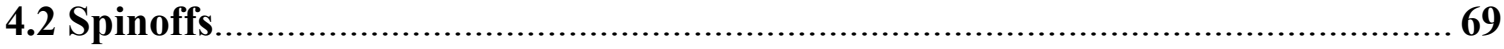



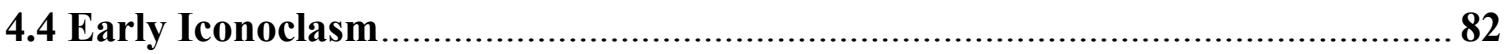

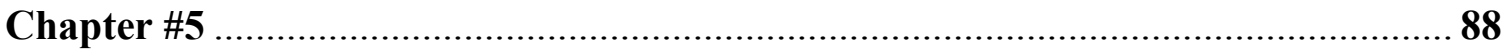



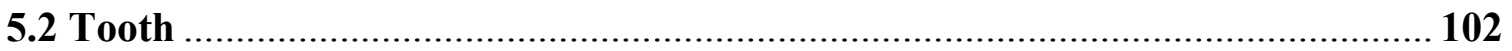

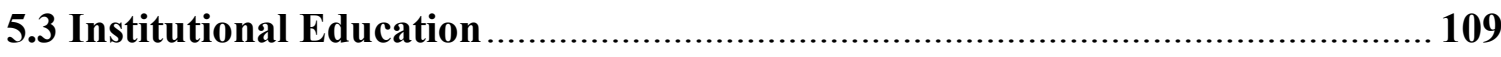

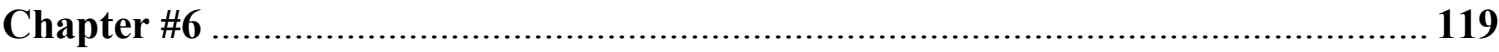

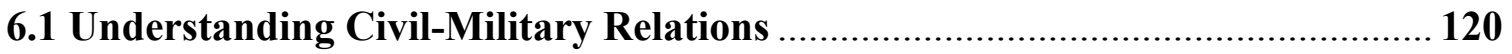


6.2 Civil-Military Relations in the Post-War Era

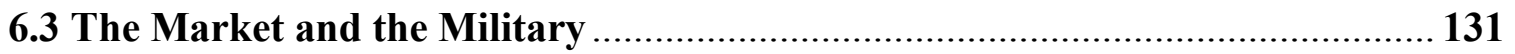

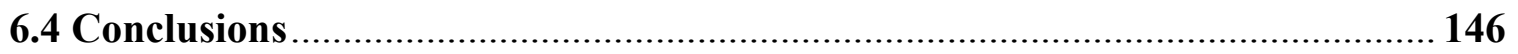

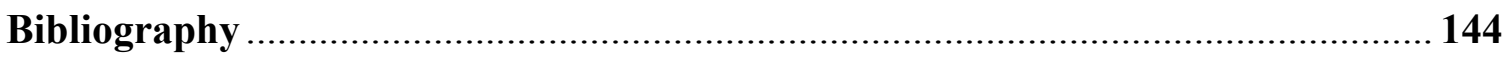




\section{Chapter \#1}

\section{An Introduction to Military Spending}

'War is not merely an act of policy but a true political instrument, a continuation of political intercourse, carried on through other means. ${ }^{1}$ Carl Von Clausewitz (Prussian General and military theorist)

Military spending is an eclectic topic of analysis, the boundaries of which ebb and flow greatly according to the historical context and theoretical approach employed. One certainty is that term 'military spending' applies to a range of government activities and so it is only natural that political considerations are central to any ontology of military spending. There are a host of non-political considerations that define the nature and form of military expenditures, the historical and comparative importance of which highlights the military's uniqueness in the pantheon of government budget items. Indeed, the relationship between the state and the military is a special one, unparalleled by any other government entity, with the military being the ultimate guarantor of the foremost prerequisite of statehood itself, the state's monopoly of legitimate violence. Yet, such a defining element of the polis is far from falling securely under the hegemony of political consideration with the military's push and pull on the forces of history decidedly unbounded by politics alone. Niall Ferguson remarked that, with the past 50 years being somewhat of an exception, 'the cost of warfare was the biggest (single) influence on state budgets $^{2}$ for all of human history with military imperatives driving the direction of state activity and guiding the very manifestation of the state itself. On occasions of great conflict where the military's role is front and centre, we observe similarly great transformations to the political process and the state. Ferguson notes that there has, for

\footnotetext{
${ }^{1}$ Carl Von Clausewitz, On War (New York: Oxford University Press, 2007) 28.

${ }^{2}$ Niall Ferguson, The Cash Nexus: Money and Power in the Modern World (New York: Basic Books, 2001) 25 .
} 
example, been a steady trend for greater political representation to be conceded to lower classes in times of conflict so as to legitimate the broad tax increases required to pursue military victory. ${ }^{3}$ While a significant observation in itself, the implications of this for the state and society are profound and it raises questions about the ability of military endeavors to shape the course of politics more broadly. For instance, even while the extension of regular direct taxation and representation beyond the upper classes gradually began during $16^{\text {th }}$ century, this process accelerated sharply during the Napoleonic wars with the adoption of mass conscription (the levée en masse) and other manifestations of warfare's democratization. ${ }^{4}$ Indeed, these were times of profound change with the centrality of the military following the French Revolution and during the Napoleonic wars (1789-1815) representing a watershed moment in the evolution of the state and society.

In 1968, Chinese diplomat Zhou Enlai was asked how the French Revolution had impacted the world, and he responded that it was 'too soon to say'. The reader will find that this type of long-run perspective and contextualization of the present through the distant past to be a recurrent theme of this work. Even before this 'long $19^{\text {th }}$ century', a strong association has existed between the inclusiveness of warfare and the inclusiveness of civil institutions as a whole. There is indeed a strong connection between the goings on of the military and the rest of society, with George Orwell noting a correlation between democratic enfranchisement and the cost of military arms, writing that 'the following rule would be found generally true: that ages in which the dominant weapon is expensive or difficult to make will tend to be ages of despotism, whereas when the dominant weapon

\footnotetext{
${ }^{3} \mathrm{Be}$ it the example of Athens in the Peloponnesian Wars all the way to the extension of universal suffrage in Western countries following the World Wars. Niall Ferguson, The Cash Nexus: Money and Power in the Modern World 77.

${ }^{4}$ Niall Ferguson, The Cash Nexus: Money and Power in the Modern World 73.
} 
is cheap and simple, the common people have a chance. ${ }^{, 5}$

Of equal significance is the relationship of the military and warfare with economic trends, with military spending affecting, and being subjected to, powerful forces of economics. In an analysis of a similar scope, Karl Polanyi remarked that the Napoleonic wars created the impetus for dramatic changes to the British political economy, and ultimately that of the world at large. Polanyi, among others, suggests that military demands on the economy during the Napoleonic Wars could fundamentally not be met under feudalism. These demands for military products greatly strained the economy, thereby inciting rapid and fundamental changes to its economic, and ultimately its political, structure. These demands on the market were so substantial that they created widespread food deficits and economic turmoil for the lower classes, necessitating dramatic reforms to the relief system in an attempt to address an overwhelming condition of rural poverty. 'This created an entirely new category of poor, the unemployed., ${ }^{6}$ This newfound dependence on wages for sustenance effectively brought about the wider inclusion of market principles to society; specifically, that there is a market for labour. These circumstances, Polanyi argues, would underlie the emergence of the industrial revolution and the market economy at large, indeed a cataclysmic shift in the nature of the economic system.

Paul Kennedy also made very important observations on the relationship between the military and the political economy of the state, suggesting that, while military power stemmed from political economic structure, that the military itself was a dramatic influencer of that very structure. Although for different reasons, he would fundamentally

\footnotetext{
${ }^{5}$ It is worth noting the full quotation here for the benefit of the reader: 'I think the following rule would be found generally true: that ages in which the dominant weapon is expensive or difficult to make will tend to be ages of despotism, whereas when the dominant weapon is cheap and simple, the common people have a chance. Thus, for example, tanks battleships and bombing planes are inherently tyrannic weapons, while rifles, muskets, long-bows and hand-grenades are inherently democratic weapons.' (George Orwell "You and the Atomic Bomb," Tribune October 19" 1945.$)$

${ }^{6}$ Karl Polanyi The Great Transformation. (Boston: Beacon Press 2001) 232
} 
agree with Polanyi, noting that the Napoleonic wars boosted production of all the resources that would prove fundamental to the industrial revolution following the conflict. ${ }^{7}$ As the military increased the demand for steel, the demand for steel inputs such as coal, iron and railroads (to transport the steel) also increased. With more coal being produced, more railroads were necessary for the transportation of coal, and railroads themselves required iron and steel to make tracks and engines, which in turn required more coal for the smelting process- that also had to be transported by railroad. In this way, military demand incited an upwards cycle of demand and production for the precisely materials that were crucial to the industrial revolution. ${ }^{8}$ At a micro level, the training and development of human capital to meet the needs of Napoleonic Wars played a direct role in the emergence of the industrial revolution as well, with demilitarization providing a wage glut in one of the few professions with the requisite skill to forge the steam engines so necessary for railroads and coal mining. ${ }^{9}$

There is ample historical and contemporary evidence to establish a clear connection between military spending and trends of the national political economy; what remains is to establish and illuminate the causal relationship between the two, thereby identifying how military spending affects the economy. The central question this work ultimately seeks to address whether, all things held equal, military spending has a positive impact on economic progress, is benign, or whether it serves to stunt human development. This question is not as simple as might seem at first glance. With the military playing a unique role within the ontological foundations of statehood,

\footnotetext{
${ }^{7}$ Paul Kennedy The Rise and Fall of the Great Powers (New York: Random House 1989) 115 -130.

${ }^{8}$ It should be noted that Kennedy is not the only scholar to take note of this phenomena, in fact there is a chorus of intellectuals who have made similar observations. Kennedy has been selected specifically because of his wealth of other contributions to understanding the military and political-economy. Paul Kennedy The Rise and Fall of the Great Powers (New York: Random House 1989) 145-158

${ }^{9}$ Vernon W Ruttan Is War Necessary for Economic Growth? Military Procurement and Technology Development (University of Minnesota. Collegeville, Minnesota. October 9th, 2006) Clemons Lecture.
} 
considerations of statehood are forcibly intertwined with answers about the economic effects of military spending. There are also moments in this analysis when the artificial separation of political and economic considerations is of limited usefulness and in those cases; it becomes necessary to speak of the military's relationship with the course of human history. Indeed, much of the literature has done precisely that, and wherever possible, this work includes in its analysis both the unquantifiable effect of military spending along with those that are more strictly quantifiable. All told, this work analyses the observed secondary effects and predispositions of military spending so as to catalogue, understand, and ultimately provide a basis to predict, the impacts of military spending on the economy.

The intellectual landscape pertaining to this question is substantial, variable and extremely conflicted. On one side of the ledger, consider the argument that military necessity and spending habits serve to pull society forward, providing the impetus for dramatic change at the tipping points of human development. While certainly not the foremost intention of military spending policies, there is doubtless a relationship between the forward march of humanity and that of service people. There is a great deal of precedent for the argument that the military pushes humanity forward, with the preSocratic Greek philosopher Heraclitus famously arguing that, 'War is the father of all things'. ${ }^{10}$ It is conversely worth considering that military spending may not represent the 'tip of the spear' of human development but perhaps rather a bell-weather, with records of military events and spending practices being the most reliable observations of the trends that were already underway at the time, in a spectacular and memorable fashion. History is written by the victors, making it altogether possible that selective memory and

\footnotetext{
${ }^{10}$ Daniel Graham 'Heraclitus'. The Stanford Encyclopedia of Philosophy. (2011) ed. Zalta, Edward. $<$ http://plato.stanford.edu/archives/sum2011/entries/heraclitus
} 
chronocentric bias ascribe military action with an undue importance not borne out by an even-handed analysis. It could well be that the opportunity costs of military spending are usually greater than what they were able to achieve in human development. A more Marxian approach would take this argument a step further, suggesting that the influences of military priorities in human action are inherently regressive. Any correlation between military advancements and those of society at large, while fundamentally indisputable, are flawed, with military influence impeding a more direct pathway to human development. While these questions may seem rhetorical, the uncomfortable fact of that matter is there is little certainty of military spending's role in the political economy or its effects.

This poses some interesting limitations for this work's methodology. On even the most practical matters pertaining to military spending, there are stark differences in what are normally the most objective statistical indicators of an institution's nature and behaviour. An illustrative example is how the recent and most scientific cost estimates for Canada's proposed procurement of F-35 fighters still diverge widely, ranging from $\$ 45.8$ billion to $\$ 126$ billion. ${ }^{11}$ This variation represents a quantifiable level of uncertainty that is in fact quite remarkable. Consider for a moment that the purchase price of this equipment may be as much as $280 \%$ higher than estimated, not to mention what are sure to be similarly divergent appraisals of the end product's usefulness. Even this not insignificant surface-level disagreement pales in comparison to the substantially more divergent estimates of the 'spin off' contribution that this military spending will accrue to the Canadian political economy. This type of uncertainty is not limited to Canadian military procurement in the $21^{\text {st }}$ century, but rather has a long and colourful history since

\footnotetext{
${ }^{11}$ Steven Chase, 'F-35 costs at least $\$ 10$ billion higher than Ottawa estimates, expert says." The Globe and Mail. April $28^{\text {th }}, 2014$. < http://www.theglobeandmail.com/news/politics/f-35-costs-could-double-overprograms-life-expert-says/article18325378/>.
} 
the time that questions first arose about the nature of military spending. With such shaky quantitative fundamentals, even a cursory analysis of military accounting statistics vindicates Mark Twain's famous quote that, 'there are lies, damn lies, and statistics.' Rather than to be led astray by unreliable numerical estimates or to limit the scope so much as to only dissect a specific policy or procurement process, this work seeks to shed light on the totality of military spending by relying more on ontology and institutional behaviour than on quantitative analysis. In essence, it seeks to determine how military spending performs differently than other types of comparable non-military expenditures.

This brings the characteristic attributes of military spending to centre-stage by controlling for the kind of illusory connections and associations which tend to hound most inquisitions into military budgeting. Viewing military spending in the raw, across many countries and time periods, it becomes quite clear that most categories of military spending tend towards producing negative, or benign, economic effects. Equally clear is the frequency with which military spending is found to be employed to perform functions for which it was not intended but are indisputably critical roles in the political economy of the state. This work then argues that it is the relationship of the military to statehood that is the key determinant of military spending's nature and behaviour, with the nonmilitary governance imperatives statehood driving the tendency for military spending to underperform by economic metrics.

The theories underpinning this new political economy of military spending are explored in Chapter \#2, with the chronology of their development set against the background of the emergence and development of the state itself. This deconstruction of military spending's ontological foundations borrows from the great thinkers of Western political philosophy, including Hobbes, Locke, Marx, and Keynes, to provide a basis for workable theory and empirical observation. Keynes continues to return as a 
formidable interlocutor as the subject of analysis shifts in Chapter \#3 to questions of statehood in the post-World War Two era. Certainly this is unsurprising, given the impact that Keynes had on the welfare state but Keynes is also important for shedding light on the economic interchangeability of military and social welfare spending. It seems furthermore that military spending and social security service similar political constituencies and are a response to comparable features of statehood. This interaction between the state and military spending arises again in Chapter \#4 when examining the role played by military spending in innovation and scientific advancement. Mary Kaldor, Ron Smith and Gwynne Dyer ${ }^{12}$ all engage with this subject by sketching out the perimeters of post-War military policy and colouring the disposition of military R\&D to contribute meaningfully to scientific advance. The activities of the military are similarly inseparable from the labour market, a term crudely approximating the dynamics of human interaction in the world of work. Chapter \#5 pulls down this artificial separation of military and civilian labour markets with the help of John McGrath and David Grossman to explore the human effects of military spending. Chapter \#6 seeks to blend the budding political economy of military spending with an analysis of civil-military relations, engaging the worlds of Samuel Finer, Ron Smith and Jonathan Kirshner. Overall, this work has the ambitious goal of mapping the contours of military spending in the political economy of the state, paving the way for future scholarship and better policy.

\section{Chapter \#2}

\footnotetext{
${ }^{12}$ The works of Gwynne Dyer, particularly 'War', constitute some of the most prolific and widely applicable commentaries available on the subject of war and the military. Due to the significant influence of Dyer's works and their formative impact on a generation of emerging thinkers in this field (this author included), it seems only fair to include reference to Dyer where more academic sources are not readily available, or directly applicable, in spite of his sometimes dubious historical sources.
} 


\section{A Brief History of the Military: Theories of Political Economy}

'In theory, theory and practice are the same. In practice, they are not.'

-Albert Einstein (Nobel Laureate, pacifist and advocate for the development of atomic weapons)

There are seemingly incompatible theoretical perspectives which govern the landscape of thought on the subject of military spending. The extent of these deep-rooted theoretical disagreements is so fundamental that there is little in the way of basic common ground, even on elementary questions such as the purpose for which the military exists in the first place. While perhaps the three major theoretical traditions will remain unreconciled on that particular question, they each shed light on military spending's effect on economic development and as such, each merit close attention. At times, military spending will behave as outlined by one theory or another, only for historical conditions to uproot this perspective's predictive power. This makes it necessary to explore theory broadly without relying too heavily on any one theoretical perspective, lest its explanatory power in a particular situation be swept away by the forces of history in another. As circumstances will dictate whether $\mathrm{H} 2 \mathrm{O}$ is best understood to be a solid, liquid or gas, so too do circumstances dictate whether the properties of military spending will be best understood through the lens of Liberalism, Statism or Marxism. Each family of theory engages with the subject of the military from a different angle and brings different insights to how the military relates to the rest of the political economy of the state. Beginning with the birth of liberal theory and the state's emergence as a political institution, there are clear tensions underlining the military's interactions between the rest 
of state's political economy. All subsequent theories recognize and identify similar tensions from these early beginnings of the state, all the way to the present-day. Although moments of consensus are rare and brief, the divergent theories of political economy do share commonality on one theme; the military has a troubled relationship with economics.

\subsection{The Birth of the State and the Liberal Tradition}

A share of society's wealth has been allotted for the military since time immemorial. Indeed, 'for most of history, war has been a more or less functional institution... Only in the past century have large numbers of people begun to question the basic assumption of civilized societies that war is inevitable and often useful. ${ }^{13}$ As such, most of the classical literature on political economy shies away from addressing the underlying reasons for why a military must exist. In the Westphalian ${ }^{14}$ state-centric $^{-}$ world in which classical theory emerged, the state is taken for granted as an unavoidable part of 'civilized society'. Most observers of the state's evolution tend to see the development of the state and the military as interwoven with one another.

Charles Tilly, for instance, commented, 'War made the state and the state made war, ${ }^{15}$ and Gwynne Dyer that 'the solider was one of the first inventions of civilized society' ${ }^{16}$, both making reference to the fact that warfare created the need for professional militaries which themselves breathed life into the state apparatus. Ultimately, 'the

\footnotetext{
${ }^{13}$ Gwynne Dyer War (Toronto: Random House, 1985) 2.

${ }^{14}$ Referring of course to the Peace (Treaty) of Westphalia in 1648 which established the basis for the modern concept of state sovereignty.

${ }^{15}$ Charles Tilly, 'War Making and State Making as Organized Crime' Bringing the State Back In. (Cambridge University Press 1985) 169-186.

${ }^{16}$ Gwynne Dyer War 6.
} 
development of state bureaucracies, scientific knowledge, and mass education in Europe (all) were shaped by, and they in turn shaped, the development of the modern military institution. ${ }^{17}$

Thomas Hobbes, one of the pillars of classical political theory, lived through the early beginnings of this process. ${ }^{18}$ His appraisal of the political evolution underway during his time was certainly in agreement with the more contemporary scholars noted above, with Hobbes famously arguing that the state's coercive ability is a necessary part of its very existence. Hobbes suggested that the state needed to be a 'Leviathan', an irresistibly powerful force whose overwhelming capacity for violence would embody a near monopoly of coercive force, thereby establishing state-sovereignty. This would prevent the re-emergence of 'the state of nature', an uncivilized prehistory of 'war(re) of every one against every one. ${ }^{19}$ In other words, Hobbes theorized that the state's capacity for coercion would in itself act to deter violence within the state and create the conditions for an internal peace. Despite coercion's centrality to the state's existence, classical thinkers, especially later ones, would often view the military with mixed feelings. John Locke ${ }^{20}$ argued for the necessity of firm limitations on the state's power. The state, he argued, should exist to guarantee the innate rights of individuals and to provide only the most basic conditions and public goods necessary to enable individuals to pursue these rights, which he defined as "Life, liberty and estate." 21

These limitations imposed on the state would ensure that it would not grow too large,

\footnotetext{
17 Theo Farrell, "Global Norms and Military Effectiveness.” Creating Military Power. Eds Risa Brooks and Elizabeth Stanely (Stanford: Stanford University Press 2007) 140.

${ }^{18}$ Hobbes living roughly between 1588 and 1679 , although there is some uncertainty about the exact years of his birth and death.

19 Thomas Hobbes Leviathan (New York: Cosimo Books, 2009) 72.

20 John Locke died almost 100 years after Hobbes, living roughly between 1632 and 1780.

1621 'Estate' in this quotation is also sometimes mistakenly replaced by the term 'property'. John Locke Two Treaties of Government (Cambridge: Cambridge University Press 1988) 222.
} 
powerful or oppressive. It's important to take note of some tensions between Hobbes' and Locke's works which set course for the liberal tradition's future interpretations of the military. On one hand, theorists like Locke imagine the ideal state as one which is minimal, in that it stays out of the realm of the private lives of individuals and does not interfere with the rights of citizens any more than absolutely necessary. However, the 'Leviathan' described by Hobbes, with its overwhelming concentration of power, possesses the ability to undo these guarantees of liberal individualism and trample the private freedoms of the citizenry. Thus for these theorists, the military is viewed as an institution that although unquestionably necessary to the existence of the state, is also itself somewhat problematic for liberalism.

Since even the most minimalist state is still bound to possess sovereignty, which by definition requires the coercive capacity that the armed forces provide, ${ }^{22}$ the gravity of Hobbes' argument has been inescapable for the political philosophers that would follow. As sovereignty is underpinned by the presence of military power, there exists a subtle parenthesis in the liberal theorization of the state which establishes the military as a necessary guarantor of the state, which turn exists to guarantee personal liberty. In other words, the military's relationship with liberty is understood to be equal parts threat and saviour. The result is a constant tension between the necessity of the state and the pursuit of individual liberty, which is manifested in liberal undertones of distrust of state power. This liberal distrust of the concentration of power in the state is perhaps most famously embodied Lord Acton's quote that, 'Power tends to corrupt and absolute power

\footnotetext{
${ }^{22}$ Max Weber famously equating sovereignty with 'a monopoly of the use of legitimate force', now employed as the most widely accepted definition and much in line with the views of these classical theorists. While this essay steers clear of actively employing Max Weber's definition, so as not to invite confusion between the views of classical liberal theorists and more contemporary theorists, it is appropriate to at least acknowledge here Weber's substantial contribution to the subject matter.
} 
corrupts absolutely.' implying that anything but a plurality of power should be viewed as inherently malign. ${ }^{23}$ This has often taken form in the strong dislike of state involvement in private affairs, even when pertaining to the activities which are the most fundamental to the operation and continuation of the state. The result is that the profession of arms is criticized by classical authors for everything but being unnecessary. On one hand, the coercive ability of the military is viewed with cautious suspicion and on the other, the conscription of goods and people for the military is regarded a questionable interference in private affairs. It is at this point in the evolution of liberal theory that the double acceptance and lamentation of the military necessity begins to take form in the works of Adam Smith. ${ }^{24}$

In contrast to some contemporary interpretations of his work, Adam Smith does not deny the important role of the state and the activities in which it engages. The production of public goods by the state, he argues, plays an important role in enabling society to generate wealth. Often-used examples of this include Smith's portrait of a lighthouse, a public good which prevents shipwrecks but cannot turn a profit for its owner. Similarly, Smith mentions that public roads, although invaluable to their users, are an unprofitable enterprise for private industry to undertake. ${ }^{25}$ Smith takes the military to be a comparable type of public good; in other words that the military is an undertaking which benefits the whole society although unable to generate a profit in its own right. Picking up from the Hobbesian tradition, Smith agrees that the military is a necessary institution of the state because of its monopoly on coercion and its role in the

\footnotetext{
${ }^{23}$ Lord Acton has been quoted because of the level of notoriety this phrase has gained, but a similar quote could just as well be attributed to Locke, or more contemporarily, even Hayek or Mises.

${ }^{24}$ Adam Smith died approximately 100 years after Locke and 200 years after Hobbes, living between 1723 and 1790. It is worth noting these dates as the works of these authors' follows the evolution of the state is close proximity.

${ }^{25}$ Adam Smith, Wealth of Nations (New York: Bantam Books, 2003) 917-931.
} 
defence of territory, yet contradictorily he also somewhat regrets the military's continued existence. Taking his argumentation one step further than previous classical theorists, Smith clearly acknowledges that the energies dedicated to the military are largely unfruitful in their own right. In The Wealth of Nations, he divides labour into the categories of 'productive', those which contribute to the wealth of nations and 'unproductive', those which do not, and he clearly identifies the military as falling into the latter category.

'...all the officers both of justice and war who serve under (the sovereign), the whole army and navy, are unproductive labourers. They are servants of the public, and are maintained by a part of the annual produce of the industry of other people. Their service, how honourable, how useful, or how necessary soever, produces nothing for which an equal quantity of service can afterward be procured. ${ }^{26}$ While later acknowledging the deterrent value of military spending, both to external menaces and internal threats, and its crucial importance to the existence of the state, he nonetheless argues that military spending presents a net loss to society. However, realizing the implications of this argument for sovereignty and the existence of the state, tied in with his overt critique of military spending, Smith stops short of shrugging off the importance of the state's coercive ability altogether and accepts spending on the military as necessary, albeit unfortunate. Thus the military is viewed in a peculiar light by classical theorists; the military is simultaneously a valuable pillar of the liberal state and as a deeply wasteful necessity, to be minimized as much as possible. Mark Blyth aptly sums up this liberal perspective on the state, and military, with the phrase, 'the

\footnotetext{
${ }^{26}$ Adam Smith Wealth of Nations 423.
} 
state: can't live with it, can't live without it, don't want to pay for it ${ }^{27}$. Yet buried within this deep-rooted schizophrenia about the state and military, there is nonetheless a certain degree of acceptance of the value of military power and the benefits that it can bring.

Although regarded as wasteful and unproductive, military spending does accrue at least one indisputable benefit to the spender; the ability to coerce rivals. Indeed, coercion short of violent interaction is perhaps the only consistently productive value produced by the military from a classical perspective, in a tradition going as far back as Hobbes.

Similar to Hobbes' musing on the Leviathan holding back 'the war of everyone against everyone', investment in the armed forces is also employed to deter 'the war of them against $u s^{\prime}$. '(Military) deterrence... is a communication. ${ }^{28}$ to the attacker that it is not valuable to proceed; that their losses from engaging in warfare will be greater than their potential gains in territory and plunder. To entertain a more aggressive perspective of international relations, the military's deterrent value can be employed offensively in the form of threatening and posturing, through which it may be possible to yield real economic dividends by coercing and cajoling other states, or possibly even $^{29}$ through territorial gains. Similarly, a substantial military investment also has the potential to yield dividends with less powerful states kowtowing to those with greater military capability.

Indeed, it is important to recall Carl Von Clausewitz ${ }^{30}$ famous aphorism that, 'War is not merely an act of policy but a true political instrument, a continuation of

\footnotetext{
${ }^{27}$ Mark Blyth Austerity: The History of a Dangerous Idea (Toronto: Oxford University Press, 2013$) 106$. ${ }^{28}$ Michael McCanles, "Machiavelli and the Paradoxes of Deterrence," Diacritics. Summer 1984: 11. 29 This emphasis exists because despite popular opinion to the contrary, very few military engagements actually result in any lasting change in territory.

${ }^{30}$ Carl Von Clausewitz (1780-1831) was born around the time that John Locke died and lived through the Napoleonic Wars as a general, military theorist and instructor.
} 
political intercourse, carried on with other means. ${ }^{31}$ The implication of this is that the real returns that military spending is able to achieve should be comparable to those of other civil expenditures. Put otherwise, the military is not immune from other matters of state and rather is a function of them. Therefore, even the most realpolitik and aggressive perspective on the military must draw conclusions about the productivity and payoffs of military endeavours. In other words, even while mistakes are made and wars erupt where no side is a benefactor, military action is ultimately guided by a no less rational objective than other types of state policies. Sun Zhu (544-496 BC), a general and author of the famous treatise The Art of War, similarly agreed that combat itself is wasteful and should be avoided whenever possible. 'In the practical art of war... to shatter and destroy it is not so good... therefore the skillful leader subdues the enemy's troops without any fighting. ${ }^{132}$ Thus whether employed offensively or defensively, the primary value of the military is in its use for deterring and posturing, since this where the economic dividends accrue to military spending. Unlike other forms of state expenditure which yield some (although decreasing) economic returns if they are in excess of the ideal amount, any military spending above the most minimal amount necessary yields no additional economic benefit. This makes a strong incentive for even the most realist ${ }^{33}$ state to invest in military power according to the classical liberal formula of minimal military spending to address the threat environment, well in accordance with classical liberal theory. In summation, while there is some inherent

\footnotetext{
${ }^{31}$ Sometimes mistakenly quoted as, 'war is a continuation of policy by other means.' Carl Von Clausewitz, On War (New York: Oxford University Press 2007) 28.

${ }^{32}$ Sun Tzu "The Art of War" The Puppet Press, 2003, January 27, 2014 $<$ http://www.puppetpress.com/classics/ArtofWarbySunTzu.pdf $>$. 46-48.

${ }^{33}$ The term 'realist' being employed to describe the perspective of international relations which views the state and state power to be the most important, if not only, guise through which actors relate with one another. Through this perspective, the maximization of state power is the primary objective of all actors in international relations.
} 
value attributed to the military in classical theory, the value of the military spending is perceived to be extremely minimal.

\subsection{The Critical Tradition}

Moving on from the classical theorists, Karl Marx ${ }^{34}$ and the Marxian tradition of political thought places the military within a very different ontology. Unlike the classical theorists which take the state and military for granted as inevitable pillars of civilization and sovereignty, Marx begins his theorization by shaking off assumptions about the monopoly of violence and of the state system itself. In fact, Marxist theory even doubts the importance of the state and the military altogether, viewing the two with a deep-rooted skepticism and doubting their necessity in society. Marx would understand the origin point of the modern state and society to be class relations. This understanding would see the state as in discontinuity with the traditional organizations of society, and Marx understood the state to be a reflection of the same old class conflicts that existed in feudalism; the rich against the poor. Marx stated, 'The modern bourgeois society that has sprouted from the ruins of feudal society has not done away with class antagonism. It has but established new classes, new conditions of oppression, new forms of struggle in place of the old ones. ${ }^{.35}$

Understanding the composition of society to be built upon the basis of the classes that rule and classes which are ruled, the state is taken to be simply a continuation of old relationships in a new, but fundamentally consistent, power configuration. The state, and similarly the military, are viewed to be artificial constructs

\footnotetext{
${ }^{34}$ Founding father of the Marxist traditional of political and economic thought, Marx was a 'babyboomer' of the Napoleonic wars that lived and wrote during the industrial revolution and the first wave of globalization. Marx lived between 1818 and 1883.

${ }^{35}$ Karl Marx and Fredrick Engels, “The Manifesto of the Communist Party," Marxists Internet Archive, 2010. January $27^{\text {th }}, 2014<$ http://www.marxists.org/archive/marx/works/download/pdf/Manifesto.pdf $>$ 14.
} 
which exist to embolden the interests of the ruling class and sustain its continued rule over everyone else. To Marx, 'the executive of the modern state is (in this sense) but a committee for managing for managing the common affairs of the whole bourgeoisie, ${ }^{36}$ and does not exist to benefit the whole of society, but a select few that comprise the elite. While the military itself is predominantly composed of proletariat, or non-elites, the military is an institution which has been built in opposition to the proletariat's real interests. Rather than the state and military being neutral actors existing for the preservation of order and civilization above all else, like in the liberal tradition, the Marxist perspective presents the state as having taken sides in an ongoing class struggle. The military is seen to sit quite clearly on the side of the rich, in opposition to the interests of the poor. More subtly, the lower classes are employed by the state to man armies and fight in wars against the lower classes of other nations, ensuring that the global proletariat's awareness of their situation is 'veiled by religious and political illusions $^{\prime 37}$. This situation reinforces fictional bonds of nationality and maintains the submission of the lower classes, with the end goal being to sustain the bourgeoisie's power over a fractured, weak and unconscious proletariat. ${ }^{38}$

Marx's intellectual successors, most notably Vladimir Lenin ${ }^{39}$, went on to suggest that the bourgeoisies' interest has effectively become global in scope due to the progressive evolution of capitalism. From Lenin's perspective, exhausted domestic opportunities to make large profits force the united bourgeois cartels to seek external markets where their capital may be employed and achieve greater returns. (This is part

\footnotetext{
${ }^{36}$ Karl Marx and Fredrick Engels, "The Manifesto of the Communist Party." 15.

${ }^{37}$ Karl Marx and Fredrick Engels, "The Manifesto of the Communist Party." 15.

${ }^{38}$ Karl Marx and Fredrick Engels, "The Manifesto of the Communist Party." 19

${ }^{39}$ Vladimir Lenin, a communist revolutionary theorist in his own right, lived between 1870 and 1924. Lenin was witness to the tail end of the industrial revolution, the first wave of globalization, and its collapse as a result of the First World War.
} 
and parcel of the economic crisis inherent to capitalism, which requires the capitalism to voraciously stumble from untapped market to untapped market in order to survive.)

Rather than come in conflict with one another, these bourgeoisies have eventually come to cooperate with one another for their mutual self-interest.

'Monopolist capitalist associations, cartels, syndicates and trusts first divided the home market among themselves and obtained more or less complete possession of the industry of their own country. But under capitalism the home market is inevitably bound up with the foreign market. Capitalism long ago created a world market. As the export of capital increased, and as the foreign and colonial connections and "spheres of influence" of the big monopolist associations expanded in all ways, things "naturally" gravitated towards an international agreement among these associations, and towards the formation of international cartels. ${ }^{40}$

To this end, the military is not used to protect one domestic bourgeoisie from another, but rather to serve the global bourgeoisie in its ceaseless quest to open more markets to capital. The military's purpose is thus to coerce, or overthrow, the leadership of noncompliant states existing outside of the capitalist system, through their subordination into colonies if necessary, so as to open the whole world to the floodgates of capital. Thus Imperialism, this never ending search for new markets inherent to the capitalist system, is the crucial purpose of the military more than the simple

\footnotetext{
${ }^{40}$ Vladimir Lenin, "Imperialism: The Highest Stage of Capitalism." Marxists Internet Archive, 2008, December $5^{\text {th }}, 2013 .<$ http://www.marxists.org/archive/lenin/works/1916/imp-hsc/ch05.htm>.
} 
maintenance of the bourgeoisie's brute dominance over the proletariat. While the 'capitalism as imperialism' framework may astutely describe much of global international relations and military expenditure during the 1800s and early 1900s, the time in which Lenin lived, the resentment and disillusionment fomented in First and Second World Wars began to loosen the bonds of formal imperialism and alter global power structures after his death. The glory of war and empire was dimming for all and the willingness to support military adventurism was dissolving.

Following the First World War, popular disillusionment with the conflict began to bring some of these Marxian criticisms into the mainstream. No longer was an existential skepticism of the military's mission just restricted to 'card carrying communists', but also military officers themselves. The renowned American Brigadier General Smeadly Butler (1881-1940) provides a good case in point. A highly decorated career soldier in the United States army, General Butler became one of the most famous critics of imperialism and war, stating, 'War is a racket. It always has been...It is the only one in which profits are reckoned in dollars and the losses in lives...It is conducted for the benefit of the very few, at the expense of the great many. ${ }^{11}$ Although public acceptance of overt classical imperialism was beginning to recede, the fundamental economic necessity of the capitalist system to continue sending capital from imperial countries abroad and to accumulate wealth remained strong. As such, while many of the overt characteristics of imperialism began to fade, the attitudes and actions of developed countries towards the developing world remained, in many ways, unchanged. In effect, while capitalism had begun to evolve past imperialism, the root political-economic cause of imperialism had not in fact been undone. Immanuel Wallerstein (1930-)

\footnotetext{
${ }^{41}$ Smeadly Butler, War is a Racket, (Port Townsend: Feral House, 2003) 23.
} 
described this evolution through his 'World System Theory'.

'World economies are (effectively) divided into core and peripheral areas...The division of a world economy involves a hierarchy of tasks in which tasks requiring higher levels of skill and greater capitalization are reserved for higher-ranking areas... the geographical maldistribution of (these) occupational skills involves a strong trend toward self-maintenance. The forces of the marketplace reinforce them rather than undermine them... Hence, the ongoing process of a worldeconomy

tends to expand the economic and social gaps among its varying areas in the very process of its development. ${ }^{42}$

In the new global capitalism, 'peripheral' countries would still find themselves subordinated to the capitalist 'core', but in a different process than before. This 'Neocolonialism' would oversee the continued exploitation of the periphery, but, this time, with the support and acquiescence of indigenous elites. With the gradual devolution of power and eventual occurrence of decolonization, indigenous elites would begin to inherit the state apparatus from the colonizers. Yet this would, in a pathdependant fashion defined by the past, where indigenous elites would sustain the oppression of the lower classes and the economic relations that had existed under colonialism. As predicted by Franz Fanon ${ }^{43}$ during the emergence of post-colonialism, 'The apotheosis of independence becomes the curse of independence.

The sweeping powers of coercion of the colonial authorities condemn

\footnotetext{
${ }^{42}$ Immanuel Wallerstein, The Modern World System: Capitalist Agriculture and the Origins of the European World-Economy in the Sixteenth Century (New York: Academic Press, 1976) 231.

${ }^{43}$ Algerian revolutionary, doctor and intellectual, Franz Fanon lived through the Great Depression, Second World War and Algerian war of independence. He was born in 1925 and died in 1961.
} 
the young nation to regression... The former colonized territory is now turned into a economically dependent country. The former colonizer, has kept intact and, in some cases, reinforced its colonial marking channels. ${ }^{44}$

In this sense, the contemporary state system itself is a result of the capitalist system with core countries exporting to the periphery a form of government which ensures the continuance of capitalist imperatives. While a Marxian analysis continues to define international relations and the military in terms of domination and class struggle, there is more nuance than allowed by this strict determinism. Within the industrialized core itself, there emerged a crisis of self-doubt about the nature of traditional political-economic relations that would shake the international system to its foundation.

\subsection{Embedded Liberalism: A Post-War Synthesis}

With the minimalist state of the 1830 s to early 1900 s giving way to a larger, more active state following the First World War, it seemed for a time as though classical liberal theory, and its ability to predict political-economic relations, had been 'consigned to the dustbin of history ${ }^{\prime 45}$. However it was the Great Depression of the 1930s which truly threw the liberal political-economic theory into self-doubt and crisis. The liberalism envisioned by classical liberal theorists of a small government, limited to most minimal activities required to enable pursuit of personal liberty, had begun to fall out of vogue with its failure to address the underlying economic problems of the Great

\footnotetext{
${ }^{44}$ Franz Fanon, The Wretched of the Earth, (New York: Grove Press, 2004) 54-55.

${ }^{45}$ A quote interestingly attributed to two ideological opposites, Leon Trotsky and Ronald Reagan.
} 
Depression. Yet these circumstances were understandable from a Leninist perspective, which may explain some of the flirtation with Marxism that occurred within the military establishment during these years. Ultimately, 'Mercantilism/Leninism sees strategic conflict as a continuation of economic competition by other means... (but) liberalism/idealism sees close trading links as inhibiting military conflict; there is more to lose from loss of economic integration. ${ }^{16}$ Where it appeared that classical liberal economic policies, such as the strict adherence to the gold standard, were in fact exacerbating economic misfortunes rather than amending them, liberalism began to lose popularity. Citizens globally began to react, demanding strong interventionist government that would shield them from the cruelties of the unbridled market. With the Second World War, classical liberalism was dealt a large blow to its credibility.

While this widely resulted in the economy being pulled more tightly into the orbit of state power, in some cases it occurred to an extent so revolutionary that it resulted in an new form of state: fascism. ${ }^{47}$ In the emerging fascist states, not only was laissez faire economic liberalism understood to be discredited, but the opposite philosophy was embraced with the state and the military taking control of the 'commanding heights' of the economy. While the fascist states presented an extreme example, there remained nonetheless broad mainstream doubts about the intellectual validity of classical liberalism. With classical liberalism no longer accepted as an apt prescription for the political economy, a new theoretical framework began to

\footnotetext{
${ }^{46}$ Ron Smith, Military Economics: The Interaction of Power and Money, (New York: Palgrave MacMillan 2011) 67

${ }^{47}$ I employ the term 'fascism' rather than 'totalitarianism' because while there is a great deal of overlap in the concepts, notable scholars of totalitarianism (such as Hannah Arendt) attribute the possibility of totalitarianism to technological innovations, such as mass media, which do not play a role in the phenomena currently under description.
} 
emerge which combined the principles of the free market and liberalism with an increasingly interventionist role for the state. John Maynard Keynes ${ }^{48}$ was a major architect of this newly emerging political-economic consensus which he understood to be birthed from the organic necessities of the economic and political system. This new perspective, known as 'embedded liberalism', was explained by John Ruggie as a

'... maneuver between these two extremes to devise a framework which would safeguard and even aid the quest for domestic stability without at the same time, triggering the mutually destructive external consequences that had plagued the interwar period. This was the essence of the embedded liberalism compromise: unlike the economic nationalism of the thirties, it would be multilateral in character; unlike the liberalism of the gold standard and free trade, its multilateralism would be predicated upon domestic interventionism. ${ }^{49}$

Interestingly, Keynes also placed military spending at the centre of his analysis, arguing that the economic slump of the Great Depression had been 'cured' by the massive influx of military spending during the Second World War. The side effect of this new military spending was a huge state intervention in the economy, which raised aggregate demand in a time of need and pushed the economy out of depression. Keynes was a firm believer that, "what could be done in war could (also) be done in peace. ${ }^{50}$ or in other words, that an influx of non-military spending could also fix a lack of aggregate demand, and 'pump-prime' the economy out of depression. With this new conception of

\footnotetext{
${ }^{48}$ John Maynard Keynes was an intellectual and an economist who lived through the first wave of globalization, its collapse in the First World War and Great Depression and through the Second World War. He was born in 1883 and died in 1946.

${ }^{49}$ Robert Skidelsky, Keynes: A Very Short Introduction, (New York: Oxford University Press 2010) 393

${ }^{50}$ John Gerard Ruggie "International Regimes, Transactions and Change: Embedded Liberalism in the Postwar Economic Order.” International Organization. Spring 1982: 35
} 
the political economy, the basis had been formed for making sense of military's spending's role in the Post-War political economy of the state. Following the Second World War, most of the developed world had continued to maintain systems of governance which incorporated the major tenants of liberalism. ${ }^{51}$

Within a classical liberal frame, military expenditures must be understood as wasteful and unproductive. It is difficult to make sense of the millions of dead and the debts that occurred during the World Wars as making a net positive contribution to material well-being. Within a liberal theoretical framework, an activity as unproductive as military spending ought to constantly gravitate towards the lowest level necessary to address threats to the state. It should be of little surprise then that liberal theory encountered difficulties in remaining relevant with the rise of fascism in the 1930s and the 'total war' of the late 1930s and 1940s where military budgets exploded. During this time, military spending had become rampant despite still not being economically 'useful' since '...combat, or the potential for the same, results in wasteful military spending and deadweight losses for (those countries involved). ${ }^{52}$ Contrastingly, Marxist theory escaped this period without overt contradiction and would continue to see military spending as a tool of (neo) imperialism, capitalism and the suppression of the proletariat. However, moving beyond the strategic understandings of military spending to a more macro-economic analysis, military spending became recognized by both Marxist and mainstream perspectives for its potential to stimulate aggregate demand during economic slumps. With the rising military expenditures of WW2 often accredited with ending the Great Depression, it is commonly accepted that, 'Aggregate demand and

\footnotetext{
${ }^{51}$ In contrast to a non-liberal form of government based on the principles of Marxism or fascism.

52 Richard Cothren, “A Model of Military Spending and Economic Growth” Public Choice. 2002: 122.
} 
sectorial employment can be stimulated in the short run by increasing military expenditures ${ }^{53}$ and so, in principle, military spending became an accepted form of counter-cyclical stimulus spending. From the Marxist perspective, high military spending during times of economic crisis can be explained more precisely as

'...capitalist economic systems generat(ing) unabsorbable surpluses which, in the absence of new markets, leads to crisis and disintegration unless the state intervenes to restore demand. Military expenditures, because of their absorptive capacity, are seen to be a particularly desirable form of accomplishing this. ${ }^{.54}$

While much of embedded liberal and Marxist theories are at odds with one another, in this regard. the two theoretical traditions are eerily in agreement. In its explanation of high military expenditures, the Keynesian view also emphasizes that a lack of

'...effective demand fails to match economy's productive capacity and recession or depression ensues. In order to avoid or rectify such consequences, the Keynesian view is (thus) that government intervention in the form of fiscal, monetary or commercial policy action is necessary. ${ }^{.55}$

Even though these two perspectives continue to vary greatly in how they explain where and why military force is applied, they both recognize the value of military budgets in remedying macro-economic malaise. What came next was military spending that would be increasingly disassociated from the strategic threat

\footnotetext{
${ }^{53}$ Miles Wolpin, "Comparative Perspectives on Militarization, Repression and Social Welfare". Journal of Peace Research. 1983: 131.

${ }^{54}$ John Treddenick, "The Arms Race and Military Keynesianism” Canadian Public Policy. March 1985: 81. ${ }^{55}$ Ibid.
} 
environment and more closely tied to internal economic policies of the state. Although the destruction associated with the First World War caused many to proclaim an end of War, the reality would be much different. Even with the terrible destruction of the Second World War just a short few years later, the military remained an important element of the state and would continue to represent a huge share of the human energy. With the enormous costs associated with military mobilization directing much of economic trends, military spending would come to be an instrument of macroeconomy policy after the Second World War and into the Cold War era. Indeed, even the concept of state governance of the economy comes from military language, with the state being said to occupy 'the commanding heights' of the economy. In the end, 'Nineteenth century economists, like John Stuart Mill and Jean-Baptist Say, believed that the cost of war had made it obsolete. They were correct about the cost, but not the obsolescence. ${ }^{56}$

\section{Chapter \#3}

\section{The Military and the State: Post-War Evolution}

\footnotetext{
${ }^{56}$ Ron Smith, Military Economics: The Interaction of Power and Money 71.
} 
'Only those who are ideologically opposed to military programs think of the defense budget as the first and best place to get resources for social welfare needs. ${ }^{, 57}$

-Herman Kahn (Military strategist and inspiration for the character Dr. Strangelove)

With the purpose of the military being strategic, military spending should theoretically be determined by variables that are external to the state, specifically the international threat environment or alliance commitments. In practice, however, it is clear that a great deal of consideration is given to how military spending can be adjusted in order to affect domestic political and economic priorities as well.

'Military spending, the defense budget, is the first element in the value chain producing security. In principle, governments should determine how much is enough by adjusting military expenditure to the point where the marginal security benefit of a little more military expenditure is equal to the opportunity cost...Some, like the arms manufacturers and the military may have an interest in higher military expenditures and in presenting the threats as more pressing then they actually are..$^{58}$

In fact, there are many more stakeholders in the military budget than just those who are a part of the security value-chain and many see the military budget as a means for pursuing their own priorities. With its enormous size, the effects of military spending

57 Eds. Paul Aligica and Kenneth Weinstein, The Essential Herman Kahn: In Defence of Thinking (Lanham: Lexington Books, 2009) 34.

${ }^{58}$ Ron Smith, Military Economics: The Interaction of Power and Money 88. 
reverberate throughout the state's political economy long after their initial expenditure, making military spending an attractive component of the state's domestic policy toolbox.

While military spending is used to promote non-military policies, it has not wholly become a chimera for these domestic policies either. Often the composition of a given country's political economy results in tensions between the policies that must be enacted for complex economic and social reasons, and the values which form the country's national political ideology. Thus military spending will often perform the role of a pressure release valve of sorts, permitting political leaders to enact economic and social policies that are deemed necessary for governances, yet offend the sensibilities of the public at large. As a result, a great deal of military spending tends to be clustered around the areas of public policy that are difficult politically to 'sell' but are necessary to the continuation of the state. Being neither a legitimate conduit for political action nor for economic management, the persistence of economic interventionism through military spending presents some hard questions about why the military remains so central to the political economy of the state.

\subsection{Military Keynesianism}

Military Keynesianism can be defined as the principle which bridges the gap between the cost necessary to achieve a desirable amount of security and the actual amount of military spending. Indeed there is habitually a large gap between the cost for security and levels of spending, and many entities use this space to achieve alternative objectives. 
'In fact, national security is rarely defined in terms of some aggregate of the security of its individuals. Often, it is the interests of some elite or ruling class that defines national security and these are not always well aligned with the interests of their citizens. (Consider that) the security of the citizens might be greater if that particular nation-state ceased to exist. $^{59}$

While the purpose of this work is not to suggest alternative forms of government but to shed light on the nature of the current one, the suggestion that the nation-state or levels of military spending exist for reasons other than national security is an important one. There are many considerations and interests which affect how military spending is undertaken beyond the direct benefits this security can afford and this reality is not limited to the $20^{\text {th }}$ or $21^{\text {st }}$ century. What perhaps makes military Keynesianism unique is that it is the manifestation of these practices into an intentional and deliberate policy, whereby military expenditures have greater or equal consideration for economic ends as for those of military strategy. Certainly, the years of the Great Depression and Second World War were important landmarks in the development of military Keynesianism, with Keynes' General Theory of Employment, Interest and Money having been written in 1936 and vindicated over the course of the war. Yet it is important to recall that Keynes' theories were not widely accepted or implemented until after 1945, in the Cold War era. The Cold War era presented a conceptual difficulty to the orthodox liberal understanding that equated military expenditure to only what is strictly necessary to address threats. With the

\footnotetext{
${ }^{59}$ Ron Smith, Military Economics: The Interaction of Power and Money 55.
} 
proliferation of nuclear weapons, the emergence of nuclear arms race and the context of mutually assured destruction, the relationship between levels of military expenditure and the threat environment began to derail. In the circumstances of the Cold War, military spending became disconnected to economic justifications of its strategic value. Any additional spending was bound to be met in kind, perpetuating an arms race in which both parties gain no comparative advantage for their efforts. Furthermore, both parties would ramp up spending on weapons specifically with the hope that they would never be put to use because they would result in their mutual destruction. Gwynne Dyer, a military historian, sketches this moment in history as an exception to most of military policy up to that point,

'The post-1945 period has seen a striking change in the pattern of wars between states. None of the great powers has fought any other great power directly for the past six decades...they spend a fortune on their nuclear weapons, but they have not dared use them in war even once since 1945. Indeed, they do not dare fight one another directly at all since any fighting could directly escalate into nuclear war. ${ }^{60}$

Therefore, a new theoretical understanding became needed to provide an explanation of military expenditure that would have to take into account consistently high spending that does not produce any substantial shifting in geopolitical tectonics, nor accrue any distinct tactical advantage to participating countries. This is where considerations of the secondary economic effects of military spending come in to play. Keynesianism was all the rage in the Post-

\footnotetext{
${ }^{60}$ Gwynne Dyer, War 291.
} 
War era and was marked by, amongst other things, a recognition that the economic results of expenditure did not have to be precisely quantified in order to be valued. In a manner similar to classical Keynesianism, there are understood to be secondary economic effects that 'spin-off' from military spending, thus generating a difficult to quantify productive economic benefit that is not directly associated with the initial results of the military spending itself. The generation of valued employment, socio-economic stability and new economic opportunities are common 'spin-off benefits' that have been associated with military spending and these spinoffs have become widely cited reasons for the perpetuation of Keynesian approaches to military spending. However, the value of these spinoffs are far from universally recognized to be 'worth' the cost of the initial expenditure, nor is the military necessarily the best vessel for Keynesian policies.

Military expenditure is sometimes mistakenly presented in the public discourse as zero-sum, with military expenditures boosting economic health through their existence, or dampening economic growth through their absence. In reality, this issue is much more nuanced, and it is important not to lose sight of the fact that there are hidden costs of military spending in addition to the more directly visible economic benefits. On the one hand, at a macro-level, military spending is most commonly recognized for its potential to stimulate aggregate demand during economic slumps. Supporting this assertion, in common parlance and academic material alike, the rapidly rising military expenditures of WW2 are often credited, perhaps due in large part to Keynes, for ending the Great Depression of the 1930s. It has been commonly claimed since that, 'Aggregate demand and sectorial employment can be stimulated in the short run by 
increasing military expenditures ${ }^{, 61}$ and so, in principle, military spending can be used as a counter-cyclical stimulus spending in a fashion similar to that originally outlined by Keynes. Yet, however comparable military spending may be to nonmilitary spending, there are unique characteristics to military spending's macroeconomic effects that must be taken into consideration before inadvertently overstretching any comparison.

The most obvious peculiarity of military expenditure is that a large portion of the goods used by the military are produced for the sole purpose of enabling coercive power, which in itself causes unique secondary effects on the economy. Strictly coercive weapons are equipment such as arms (ammunition, rifles, grenades etc.) and not equipment whose primary role is the projection of that coercive ability (planes, boats, jeeps). Expenditures on weapons ${ }^{62}$ are usually a form of dead-end consumption, in the sense that they exist at the end of the value chain and do not add additional value to other new goods that might be created. Weapons expenditures, specifically for small arms, are a classic example of strictly military-use equipment because they have little to no value for nonmilitary applications. ${ }^{63}$ As a counter-example, the construction of a hammer would increase the future productivity of carpentry, adding further value to that which a carpenter is able to produce, yet a bazooka does little to increase the

${ }^{61}$ Miles Wolpin, "Comparative Perspectives on Militarization, Repression and Social Welfare," 131.

${ }^{62}$ An important distinction to be made, especially in regards to American military spending, which is one of the more commonly studied examples, is that there are also many non-military goods that are produced under military auspices and are paid for out of military budgets. This sometimes makes it difficult to generalize about the presumed effects of military expenditure in the United States since the exact composition of that expenditure will greatly affect the result. This requires an important clarification to be made between the economic implications of military expenditures whose function are strictly military, and those expenditures which could function for military or non-military purposes

${ }^{63}$ In contrast to more complex weapon systems, like missiles, which it has been argued have extensive potential for R\&D spinoff benefits because of the complex internal machinery inside which can be used in different applications. This claim is addressed in greater detail in Chapter 4 
future productivity of anything.

In this sense, a greater proportion of regularly purchased military assets are predisposed to contribute more weakly to future productivity than nonmilitary assets. The result is that, 'military expenditure (on material assets)... adds to demand but unlike spending on roads, schools, or hospitals it does little to improve productivity in the long-term ${ }^{64}$ In addition, there are serious opportunity costs to high military spending. When defence spending rises, the costs associated with it are usually funded by reductions '...out of civil government expenditures and private consumption. ${ }^{, 65}$ This inadvertently has the effect of lowering the potential for more useful spending to occur through publicsector non-military spending. ${ }^{66}$ It is interesting to note that the civil government programs which are most reduced as a result of increases in military spending are generally social programs, specifically education, health and welfare. ${ }^{67}$

'High arms burdens do usually reduce health and especially educational expenditures. Furthermore, reduced consumption, lower investments, balance of payments, deterioration, lessened productivity increases, diminished economic growth, unemployment and inflation are common "costs" which in the short or long run directly or indirectly affect mass welfare. ${ }^{68}$

On the other side of the coin, when arms expenditures are lowered, most

\footnotetext{
${ }^{64}$ Olof Palme et al, "Military Spending: The Economic and Social Consequences," Challenge. 1982: 12

${ }^{65}$ Miles Wolpin, "Comparative Perspectives on Militarization, Repression and Social Welfare," 132.

${ }^{66}$ Albert Szymanski, "Military Spending and Economic Stagnation" American Journal of Sociology, July 1973: 1-14.

"Bruce Russett, "Who Pays for Defence?" The American Political Science Review. June 1969: 420

${ }^{68}$ Miles Wolpin, “Comparative Perspectives on Militarization, Repression and Social Welfare,” 142.
} 
of these secondary effects are greatly reduced, if not eliminated outright.

Observing the permanent declines in military spending after World War II, it is clear that these declines were 'matched by a fully equivalent transfer of resources into the health and education sectors ${ }^{, 69}$. The direct opportunity costs of military spending are most closely linked to a country's social spending. In other words, there would seem to be a very direct and measurable trade-off between Keynesian social welfare spending and spending via military Keynesianism.

When these reductions in civilian budgets occur due to increased military spending, it is often the case that the foregone civilian spending would have been able to contribute much more to economic growth then the military spending would have. In contrast with military expenditures, 'public non-military investment...is argued to have positive direct and indirect effects on private sector output and productivity growth ${ }^{70}$ Higher levels of military spending entail lower levels of civilian development which, in turn, leads to lower levels of long term economic growth. Since alternative, non-military, investment spending could have contributed exponentially more to future GDP; many experts conclude that 'higher defence spending is likely to lead to...lower economic growth (across the board). ${ }^{71}$ Part of the answer may have to do with its relationship to social spending, since there is an, '...inverse relationship between

\footnotetext{
${ }^{69}$ Miles Wolpin, “Comparative Perspectives on Militarization, Repression and Social Welfare," 133.

70 David Achauer, "Public Investment and Productivity Growth in the Group of Seven," Federal Reserve Bank of Chicago, Economic Perspectives. September 1989: 17

${ }^{71}$ Paul Satya, "Defence Spending and Unemployment Rates," Journal of Economic Studies. 1996: 44. While this observation and general tendency are difficult to deny, the enormous multitude of variables which contribute to GDP make any deterministic relationship between GDP and military spending difficult to prove with total certainty. Even though there is statistical
} 
defence and welfare at most spending levels. ${ }^{72}$ In other words, in spite of

Herman Kahn's notable assertion to the contrary, military spending increases are quite clearly funded out of reduced welfare budgets and vice versa.

Much of the reason for this is that the greatest non-equipment portion of the military budget is spent on employing soldiers in the armed forces. This military payroll creates 'jobs for large numbers of unskilled workers, notably young men...who in most countries are relatively likely to be unemployed ${ }^{73}$. This lowers the unemployment rate, injects money into the economy and lowers the amount of social safety net spending that would otherwise need to take place. ${ }^{74}$ In this context, it may be understandable that increases in the military budget mostly come from social spending, and the argument has been made, inconclusively, that the military payroll may produce more human capital than social programs. But with that having been said, the military payroll 'appears to create substantially fewer jobs for a given sum of money than non-military public consumption ${ }^{, 75}$ which, again, somewhat undermines the credibility of arguments proclaiming the inherent economic productivity of

evidence to support this, let it be made clear that observations so general and so high level should be humble in what they claim to prove.

${ }^{72}$ Bruce Russett, “Who Pays for Defence?” The American Political Science Review. June 1969: 420

${ }^{73}$ Olof Palme et al, "Military Spending: The Economic and Social Consequences," Challenge. 1982: 10

${ }^{74}$ There is a careful distinction to be made here about how the effect would differ in allvolunteer forces (AVFs) and conscription militaries. On one hand, conscript militaries employ to those that are statistically likely to be unemployed where AVFs offer employment to those that are statistically likely to be unemployed. The difference being that those who are unemployed may seek a military position in AVFs whereas those who are employed may be forced to leave a position so as to switch in to military employment under a conscription regime. With this in mind, perhaps conscription results in a suboptimal result as human resources are indiscriminately taken out of the market without an understanding of whether or not they can be replaced by the existing unemployed. On the other hand, perhaps AVF, in recruiting the already unskilled and unemployed reduces the supply of unskilled civilian labour, raising wages for entry positions and effectively dooming the unskilled to military service. Implications for social equity aside, there are underlying questions as to which system of military service would result in greater macro-economic efficiencies that must be left unanswered for the time being.

${ }^{75}$ Olof Palme et al, "Military Spending: The Economic and Social Consequences," Challenge. 1982: 9 
military spending. While these inefficient results should be expected to automatically lower military spending to the minimum amount required to adequately address the threat environment, thereby minimizing military spending's drag on economic growth, this seldom occurs in reality.

\subsection{The Subtle Contours of Military Macroeconomics}

Even though the economic inefficiencies of military spending are rarely controversial, many arguments have been made in favour of employing military spending for the purpose of stimulating aggregate demand during economic downturns. This Keynesian counter-cyclical spending requires large-scale and immediate increases in expenditure in order to be effective at counteracting an impending recession, and it is suggested that these counter-cyclical stimulus expenditures can be undertaken through the military. However, there are inflationary pressures that are part-and-parcel of military spending that put military Keynesianism at a distinct disadvantage when compared to its civilian equivalent.

Strictly military-use purchases are often observed to possess an exacerbated tendency to create inflation, especially when they are accompanied by rapid increases in spending. 'Rapid increases in military spending have (long) been associated with rising prices ${ }^{, 76}$ and high inflation for several reasons. Firstly, military spending often results in demand pressures that far outstrip the existing capacities of essential industries and resources, causing these prices to rise spectacularly. Petroleum, steel and rubber are strong traditional examples; given that these materials are widely used in civilian

${ }^{76}$ Olof Palme et al, "Military Spending: The Economic and Social Consequences," Challenge. 1982: 11 
industries as well as highly demanded by the military, their price inflation quickly spills into the greater economy. Secondly, a military in war-time is capable of consuming economic resources at a level seldom duplicated by any other type of economic activity. In spite of this, a clear distinction must be made that military spending does not necessarily have to be accompanied by high inflation, even though it often is. This is because the procurement of military resources simply produces inflationary pressures on the economy, rather than inflation itself. ${ }^{77}$. Since WW2, the principal agent of these inflationary pressures, the cost of arms and equipment, has gradually gained an increasing share of military budgets since arms costs increase at a rate of approximately $10 \%$ per annum, much higher than that of other costs, most dramatically that of soldiers' pay. ${ }^{78}$ This serves to greatly exacerbate with time the already inflationary tendency of defence spending and to undermine the macroeconomic value of military spending as economic stimulus.

It is important, however, to note that the degree of inflationary pressures produced by military spending has been historically variable. ${ }^{79}$ This is due to the gradually changing composition of military expenditures and the variable proportion of military spending dedicated to arms and equipment. With the proportion of military budgets dedicated to arms having steadily increased from 1945 through to the 1980 s, the result was a greater reliance on

\footnotetext{
${ }^{77}$ Miles Wolpin, "Comparative Perspectives on Militarization, Repression and Social Welfare," 132

${ }^{78}$ Keith Hartley, “The Case for Defence," Defence and Peace Economics. 2010: 409-426 Similar calculations to these resulted in the facetious 'Augustine's Law' which, through an analysis of increasing military equipment costs, projected that by the mid-2030s all of the United States military budget would be spent operating one plane that would be have to be shared by the Army, Navy and Air Force.

${ }^{79}$ This is an important observation which helps to explain some of the myths and beliefs surrounding military spending which emerged out of the Second World War and are still commonly held today. With high inflation accompanying high military spending, it becomes more difficult to find an objective measure of cost.
} 
expensive equipment and technology, with a commensurate reduction in the payroll proportion of military budgets. Writing in 1985, John Treddenick notes that,

'...virtually all of the increased military expenditure of recent decades has been allocated to the procurement of increasingly expensive hardware. With this shift in emphasis, the direct employment potential of military expenditure is diminished..$^{80}$

The long-term trends governing what proportions of the military budget are dedicated to equipment instead of payroll is examined in greater detail later, but let it just be noted here that there are important macroeconomic implications to this. A reduced emphasis on military payroll naturally serves to undermine the effectiveness of military spending for Keynesian ends since wages paid at the lower end of the socio-economic spectrum create a higher velocity of money. In other words, these foregone military wages would have had a high multiplier effect and would have thus been a more effective stimulus for the economy than expenses on equipment. It should be of little surprise, then, that the 'increasing capital intensity of defence production generate(s) diminishing secondary employment effects beyond direct military employment' ${ }^{81}$ Furthermore, rather than jobs generated from military spending employing those that are already at risk of unemployment, military spending with a high capital intensity increasingly produces jobs in capital and research intensive industries which

\footnotetext{
80 John Treddenick, "The Arms Race and Military Keynesianism," Canadian Public Policy. March 1985: 82-83

${ }^{81}$ Paul Satya, "Defence Spending and Unemployment Rates," 50
} 
require highly skilled and highly paid labour. ${ }^{82}$ The result is that the share of military spending which does make it into payrolls will circulate more slowly. Considerations of this balance between spending on capital versus human capital is an important consideration for military spending's value in macro-economic policy, with the tendency for higher capital intensity and lower employment undermining the ability of military spending to effectively supplant welfare-type policy spending and produce effective Keynesian stimulus.

Finally, in order to be effective, Keynesian stimulus must be enacted quickly in response to a cooling economic climate. It is for this reason that many of the preferred tools of Keynesian stimulus spending are 'automatic stabilizers' because they are immediately responsive to economic circumstances. Valueadded (sales) tax is a good example of an automatic stabilizer because the amount of tax collected is determined on a day to day basis by people's spending habits. If the economic climate is good, people are taxed more because they spend more, cooling the economy while saving some government revenue for a rainy day. If the economic climate is bad and people's incomes drop, everyone is effectively awarded a tax break because they spend less and money is injected into the economy from government coffers. These automatic stabilizers contrast with large-scale government economic programs which depend both on the political process, which can be slow, and statistical data about economic health which can come too late. In fact, there is a debate about how often macroeconomic stimulus spending packages arrive too late to do any good, stimulating the economy only after the crisis has passed. With this in mind, it is

\footnotetext{
82 John Treddenick, "The Arms Race and Military Keynesianism," Canadian Public Policy. March 1985: 82-83
} 
worth noting that military spending processes are exceptionally slow, even when compared to other government spending procedures. It has been noted for instance that the $\mathrm{F} 35$ procurement process has at present taken more time and cost more money than the Apollo space program, and it is still far from completion. While there are many reasons for this overall irresponsiveness, one is that

'for budgetary issues like military spending, change must occur in an incremental manner... Making only incremental changes in the budget eliminated certain inefficiencies in the cost of prosecuting the Cold War. Annual budgets fund multiyear projects in which substantial investments are at stake; by changing military spending at the margin, many of the costs of stopping and restarting projects, or of abandoning investments only to reinvest, (have been) avoided. ${ }^{83}$

Thus it is directly in the interests of the military institution and the civilian leadership to ensure that levels of military spending remain relatively steady, regardless of the threat environment, to ensure a degree of efficiency. This makes it very difficult to tailor military spending levels to rapidly changing circumstances, such as an economic downturn or even a war. ${ }^{84}$ This is borne out

\footnotetext{
${ }^{83}$ Thomas Hartley and Bruce Russett, "Public Opinion and the Common Defence: Who Governs Military Spending in the United States?" 906

${ }^{84}$ It may be worth noting in particular that American military spending may be an especially poor tool for Keynesian stimulus to aggregate demand. Furthermore, for the purposes of analyzing the military's potential economic impacts as counter-cyclical stimulus, '...only about 13 percent of the (US) defence budget is actually spent on the protection of US borders.' (Paul Satya, "Defence Spending and Unemployment Rates," 52) The result is that much of the potential economic spill-over that an increased military footprint would entail (IE through the local purchase of supplies, wages to be expended during leave etc.) will forcibly be nondomestic. Since any military spending increases will necessarily have a large portion of its economic effect outside of the US, a great deal of the stimulus will spill-over into other jurisdictions rather than ripple through the American economy.
} 
in the historical data as '...military expenditures are found to adjust slightly less than proportionately to central government

expenditure changes. A decrease or increase as central government expenditures leads to a less than proportional decrease or increase in military expenditure. ${ }^{85}$ Put differently, military budgets are 'sticky'. This poses major macro-economic disadvantages for the use of military Keynesian policies versus whole-ofgovernment Keynesianism and makes it an ill-adapted tool for macroeconomic policy.

\subsection{Unproductivity Reconsidered}

The $19^{\text {th }}$ century American military strategist General Nathanael Greene famously stated that 'Amateurs think about tactics while professionals think about logistics' and perhaps the often cited spinoff value of military logistics will vindicate the thesis of military productivity. Firstly, it is important to right the mistakenly assumption that military power is to be a function of volume; that is to say, the amount of military personnel or equipment available for deployment represents military power. In fact, military power is perhaps better understood as a function of power's application at the right place and at the right time. As coldly expressed by Sebastian Junger, an embedded military reporter in Afghanistan, 'Modern war is essentially about maneuvering the enemy into a position where they can be slaughtered from relative safety. ${ }^{86}$ With this in mind, the ability to maneuver soldiers, their equipment and their supplies is an extremely important function of military operations with a value that far exceeds

\footnotetext{
${ }^{85}$ Daniel Hewitt, "Military Expenditures Worldwide: Determinants and Trends, 1972-1988," Journal of Public Policy. April-June 1992, 139

${ }^{86}$ Sebastian Junger, War, (New York: Twelve, 2011).
} 
the cost of logistical infrastructure. Having 10 soldiers that can be transported into theatre immediately is substantially more valuable than 100 soldiers that are incapable of arriving until after they are needed. More than this is how to ensure that these soldiers are supplied with the basic necessities as well as the proper equipment to grapple with whatever emergent situation or enemy they are likely to confront.

Multiply the gravity of these issues many times over and it starts to become clear why logistics are a very important function of military effectiveness. Certainly, 'Supply trucks, mobile depots, and ferry-like transport ships are just as important as stealth bombers and laser-guided or satellite guided bombs. ${ }^{187}$ When considering the amount of interrelated factors governing military logistics and the thousands of people involved in the process, it becomes clear that this is an area of extreme complexity and significance. As expressed by one scholar, the core difficulty of military logistics is 'How does one move the equivalent of a mid-sized city halfway across the world, and do so quickly and with enough care and prudence as to avoid possible enemy attack in the process? Then, how does one keep that city functioning as it spreads out on a battlefield and engages with the enemy? ${ }^{88}$

While the image of a 'mid-sized city' helps to describe the magnitude of this problem, the impact that this has for infrastructure remains difficult to grasp without further elaboration. Logistical infrastructure is so important that its inadequacy can be enough to 'call off' a military engagement if it is enough to prevent an adequate supply of the number of forces necessary in

${ }^{87}$ Michael O'Hanlon, The Science of War, (Princeton: Princeton University Press, 2009) 141.

${ }^{88}$ Michael O'Hanlon, The Science of War, 143. 
theatre. Consider that

'Trucks typically have a payload of five to ten tons. So roughly 100 trucks (arriving) per day are needed to supply a given brigade ${ }^{89}$...If these supplies need to move on roads... bottlenecks can develop... (adequate) resupply is generally only feasible if vehicles are in very good shape, if roads do not need to be shared with civilian traffic, if key infrastructure like bridge networks is robust (and defensible), if weather is not a major factor and if engineering and maintenance crews and equipment can keep the roads in acceptable driving condition. ${ }^{.90}$

To add to this problem, imagine that the trucks must go through hostile territory where they must move more carefully and may not refuel freely; this could easily add an additional 25 trucks per day in order to account for the extra provision for security and fuel. If the round-trip journey only takes one day, including time to load and unload the trucks, then the brigade will now require, let's say, 125 trucks to be supplied. If a round-trip journey takes three or four days, which is certainly possible where conditions are difficult and the infrastructure poor, it might ultimately require 150 trucks arriving per day in order for the groups to carry all the additional fuel necessary for the round-trip, therefore requiring 450-600 trucks ( 150 trucks per day*3/4 days of route) constantly on the road in order to keep a battalion in theatre. ${ }^{91}$ Were it possible

\footnotetext{
${ }^{89}$ Roughly 3,000-5,000 soldiers.

${ }^{90}$ Michael O'Hanlon, The Science of War, 146-147.

${ }^{91}$ Nor is an example like this particularly unrealistic especially when drawing on the example of 'The Hump' airlift between Assam (India) and Kunming (China) during the Second World War.
} 
to, for instance, upgrade the road infrastructure in a manner that would reduce the transportation time by half and to create a refuel station, thereby eliminating the necessity for the trucks which represent increased security and fuel, the battalion's resupply may only require 150-200 trucks per day instead of the original 450-600 necessary without the improvement. This would place the infrastructure's military value at the equivalent of 300-400 trucks per day, including fuel costs, operator training, wages, wear and tear and risk of attack. ${ }^{92}$ With this in mind, it is well within the realm of possibility that savings accrued from needing so many fewer trucks would pay for the cost of the road upgrade many times over during the course of the engagement. This infrastructure thus represents a huge improvement in efficiency of military logistics, and there is little doubt that a military valuation of this infrastructure would be far higher than its civilian equivalent or the basic costs of construction.

This interplay between strategic necessity and logistical infrastructure thus can result in huge infrastructure spinoffs into the civilian sector. Since the military value of well-placed infrastructure is so large, new constructed military infrastructure can pay for itself in a very short portion of its overall life expectancy. While military logistics may be conducted by vehicles, aircraft and

In the absence of an adequate land route, the Allies flew supplies to China over the Himalayas. Given the limited refuel options in Kunming, the Allied planes also had to carry the fuel with them that would necessary for a return trip. In the event of bad weather, mechanical problems or pilot error, on occasion some of these planes would make it 'Over the Hump' carrying only enough fuel to return to India and nothing else. The 3 year airlift resulted in nearly 600 lost aircraft, mostly due to flight hazards and other transportation shortcomings.

${ }_{92}$ Although not the exact example used by O'Hanlon, this calculation is closely inspired by O'Hanlon's work and similar manner of calculating infrastructure value, more specifically his chapter entitled Logistics and Overseas Bases. (Michael O'Hanlon, The Science of War, 144162.) 
ships that are exclusive to military use and may share little in common with their civilian equivalents, both civilian and military transportation are nonetheless both empowered by similar infrastructure. Put otherwise, even though a road may be built for military logistics, there is very little obstacle to this road being adapted effectively to civilian use after it has served its military purpose. Indeed, this happens often and a staggering amount of civilian infrastructure has origins in military logistics. ${ }^{93}$ In this regard, the cost-to-value ratio of the spinoffs of military infrastructure would be quite high. An often cited example might be the Alaska-Canadian Highway which was originally built as a military asset used to connect Alaska to the rest of continental US, to repulse Japanese attacks during the Second World War. ${ }^{94}$ It was used for strictly military purposes for several years until it was spun off into civilian use, where it has been pivotal to economic development ever since as the only all-season road to the Arctic. ${ }^{95}$ Similarly, many of the military airstrips built in the Canadian Arctic during the Second World War were spun off into civilian use at the end of the Second World War, providing the impetus for permanent settlements and cities. ${ }^{96}$ Especially when looking to the military infrastructure spinoffs from the Second

\footnotetext{
${ }^{93}$ One of the most notorious examples would of course be the German Autobahn system which was built by the Nazis in order to enable military forces for their invasions of neighbouring countries. Yet, one does not need to look very far for examples. In Ottawa, where this work was written, the Rideau Canal was originally built to be an alternative supply route for soldiers and military equipment in the event of another war with the United States.

${ }^{94}$ Rob Huebert, "Renaissance in Canadian Arctic Security?" Canadian Military Journal, Winter 2005-2006, 17-30.

${ }^{95}$ Kenneth Coates. "Preface," The Alaska Highway, ed. Kenneth Coates,(Vancouver: University of British Colombia Press, 1985).

${ }^{96}$ Iqaluit providing a strong example since permanent settlement occurred in parallel with the establishment of the military airbase in 1942. ("Iqaluit", The Canadian Encyclopedia. Nd.

August $6^{\text {th }}, 2012$. December $15^{\text {th }}, 2014<$ http://www.thecanadianencyclopedia.ca/en/article/iqaluit/>.)
} 
World War and the impact this had in opening up new frontiers, it seems that military logistical infrastructure has a strong spinoffs value.

Perhaps a different way to think of this problem is to analyze the example of railway building in Myanmar. A fractious country with mountainous hinterlands that are barely under the control of the central government, Myanmar determined that building railways to connect these hinterlands with the centre of the country was a matter of military and strategic necessity. Perhaps sensible on paper from a strategic perspective as this new infrastructure would allow for more rapid resupply of the military units stationed at the periphery where conflicts were most likely to occur, practically speaking these train lines are almost entirely dedicated to civilian use. From economic and military perspectives, these train lines are deeply inefficient since there is not adequate passenger demands to justify them. Yet, from a political perspective, these train lines help to bring the hinterlands back into the political fold by subsidizing their connectivity with the rest of the country. ${ }^{97}$ While this may represent a particularly egregious example of maneuvering to abuse military spending for political purposes, the key lesson to take away is that, while logistical infrastructure can be built for military purposes, its core function is ultimately more closely related to civilian activity than anything else.

This is because, while much of the logistical infrastructure used by militaries has been created by the military for military purposes, the job that this infrastructure performs is much closer to that of its civilian counterpart than it is

\footnotetext{
${ }^{97}$ Thant Myint-U, Where China Meets India: Burma and the New Crossroads of Asia, (New York: Faber and Faber 2011).
} 
completely distinct. Carl Von Clausewitz went so far as to state outright that logistical infrastructure, while crucially important to military effectiveness, is fundamentally an activity that falls more closely into the civilian realm stating, '...nothing is more common than to find considerations of supply affecting the strategic lines of a campaign and a war... Although marching can be seen as an integral part of combat, it had certain aspects that do not belong here and that therefore are neither tactical nor strategic... such as building roads and bridges and so forth...no matter how frequent and decisive these considerations may be, the business of supplying the troops remains an activity essentially separate from their use... these activities are alien to the conduct of war..$^{98}$

The similarity of military and civilian infrastructure may therefore not represent the positive infrastructure spinoffs with which the military is often associated, but is perhaps another manner in which the military has been used as a vehicle for civilian policy and spending. Indeed, if there are few functional differences between a civilian road and a military road, the major differences between the two road projects are once again procedural, with the military procedure possessing a less transparent cost-benefit analysis and being subject to a lesser degree of political scrutiny. By these measures, it seems more sensible not to think of logistical infrastructure as a military 'spinoff' at all, but rather as a civilian activity which can sometimes have overlapping goals with

\footnotetext{
${ }^{98}$ Carl Von Clausewitz, On War, 77-78.
} 
the military, regardless of which institution may circumstantially wield the relevant budget.

\subsection{The Glue of Statehood}

On the whole, the evidence would seem to indicate that use of military spending to underpin economic growth is, at its most generous, uncompetitive when compared to an equivalent amount of civilian government spending. Furthermore, in consideration of the steadily degrading macroeconomic effectiveness of military Keynesianism, one could reasonably expect, with time, a commensurate disengagement from the use of military spending for the purposes of economic stimulus. However, this disengagement from military economic policy has not clearly taken place. Instead, the use of military spending for economic ends has emerged in the $21^{\text {st }}$ century relatively intact, despite strong economic incentives for its retraction or reform. In many respects, the use of military spending for economic ends is a policy that has been well suited for the formation of political economy in the state system.

In the same fashion that military expenditures are irresponsive to change, the secondary effects of military expenditures are also subject to a great deal of lag. This delay can damage the political viability of making changes to defence policy that are responsive to economic conditions. 'For a given cut in defense spending, the magnitude of these costs (to the economy at large) depends on the speed with which labor and capital resources can be transformed to meet new demands. ${ }^{99}$ In other words, it takes a great deal of time for resources to be

\footnotetext{
${ }^{99}$ Michelle Garfinkel, “The Economic Consequence of Reducing Military Spending,” Federal Reserve Bank of St. Louis. November/December 1990, 55-56.
} 
productively reemployed elsewhere, in the United States for example '... it takes about five years for such an indirect investment (from an altered military budget) to become manifest. ${ }^{, 100}$ Since the political cycle typically dictates electoral contests more frequently than this, substantive reforms to the military budget tend to be an unattractive choice. Typically, changes made to military budgets will have their long-term positive effects on the economy only take form after the next election. ${ }^{101}$ On the other hand, the negative economic effects, the ones that will affect voting patterns in upcoming elections, will be felt immediately as military spending is reduced and voters lose the jobs that were associated with the military spending. Decision-makers are thus incentivized to ensure that military spending practices are not nimble and that inefficiencies are allowed to fester.

There are other divergent interests between political elites and citizens, namely that, 'the political leadership of a country often values military power more than the population does. ${ }^{102}$ Coercive power is much more valuable for elites who may have the ability to employ it, than it would be of value for 'Joe Public' to live in a country with a well-funded military. In other words, a strong military has significantly less effect on the quality of life of citizens than it does on the quality of life for elites, another reason why military budgets may not fall to levels that match the threat environment. With military budgets providing so much political 'wiggle-room,' it's of little doubt that elites sometimes seek to

\footnotetext{
${ }^{100}$ Michael Ward and David Davis, "Sizing up the Peace Dividend: Economic Growth and Military Spending in the United States, 1946-1996" The American Political Science Review. September 1992, 749.

${ }^{101}$ Richard Cothren, “A Model of Military Spending and Economic Growth” Public Choice. 2002, 135.

${ }^{102}$ Daniel Hewitt, "Military Expenditures Worldwide: Determinants and Trends, 1972-1988," Journal of Public Policy, April-June 1992, 109-110.
} 
address highly polarized issues of economic intervention and redistribution under the cover of the military budget. With public opinion often deeply divided about what constitutes appropriate economic interventionism, military spending is politically useful since, 'Military expenditures seem to be strangely immune to any negative associations with "big government". Nor (is it) tainted with allusions to "creeping socialism", which frequently attach to civilian public expenditures. ${ }^{103}$ In the United States, for instance, where political involvement in the economy appears to be especially controversial, the military remains one of the few budget items that tends to receive consistent support from both the Democratic and Republican parties. For a country that is so divided on the issue of government spending, 'defence spending' can serve as a politically benign explanation for what might otherwise be termed 'fiscal stimulus', 'subsidy' or 'equalization'. One could even speculate that this may be part of the reason why the Republican party usually advocates for higher levels of military spending than does the Democratic party, while tending to remain more isolationist. ${ }^{104}$ That is to say that military spending is special in that it can circumvent norms pertaining to the ideal level of government intervention to be accepted in the economy.

Military spending is also attractive for political leaders because the lack of transparency and accountability inherent to military spending permits them a greater freedom of action. 'For a number of reasons, military expenditures constitute an attractive economic policy instrument, foremost being the

\footnotetext{
${ }^{103}$ John Treddenick, 'The Arms Race and Military Keynesianism,' 82.

${ }^{104}$ Contrary to popular belief, the Democratic representatives have consistently made more use of the military in foreign affairs than Republicans.
} 
ambiguous link between defence expenditures and defence output. ${ }^{\prime 105}$ Otherwise, the ability to designate information pertaining to military budgeting as 'classified' prevents much of the details of military spending from making their way into the public light, where they would be subject to criticism. These factors serve to keep defence expenditures largely decoupled from what normal geopolitical circumstances may require, while maintaining a façade for the electorate and familiar rhetoric of minimalist government intervention. In a similar fashion, the concept of 'redistribution' can be somewhat controversial despite, in frank conversation, most public officials accept that some level of redistribution is politically and socially necessary. Military spending emerges as a solution, with the military having the capacity to cloak redistributive policies in 'National Defence' rhetoric, thereby avoiding the scrutiny of public opinion for unpopular yet necessary policies. In this light, the eclectic grouping of initiatives falling under military purview is considerably less surprising, especially the intertwining of military policies with those for the promotion of upward social mobility. ${ }^{106}$

There are other legal norms that can be circumvented by redistributive military spending for similar reasons. For one, 'in federal states, military expenditures have the... advantage of not being subject to jurisdictional questions which may impede the acceptability and effectiveness of other types of civilian policy instruments. ${ }^{107}$ In this sense, military spending can be used to complement, or supplement, inter-jurisdictional equalization transfers from higher, to lower, levels government, which might be viewed critically by the electorate. Unlike civilian spending, military spending is able to bypass

\footnotetext{
105 John Treddenick, "The Arms Race and Military Keynesianism," 77

${ }^{106}$ John Treddenick, "The Arms Race and Military Keynesianism," 84.

107 John Treddenick, "The Arms Race and Military Keynesianism," 82.
} 
discussions about transfer conditionality, the term length of the funding, and negotiations about the amount of the funding to be transferred. This is because, in theory, all of these factors are determined by strategic external threat priorities rather than by domestic considerations. In practice, the military label is often slapped onto equalization transfers as well in order to obscure the true redistributive nature of the spending and to avoid inter-jurisdictional haggling. In other words, what is particularly appealing about military-economic spending is that these expenditures take place in such a way that allows policy-makers much more flexibility in implementation than other types of spending would allow.

Geographic military constituencies are another factor playing an important role in how military spending is distributed. On one hand, military spending is exceptionally spatially concentrated in comparison with other types of government spending, making for strong geographical constituencies associated with military spending. Particularly well studied is the American example where ${ }^{108}$

'Some regions and states will suffer sizable job losses from defence cuts. Many of these areas are located on the two coasts, particularly New England, areas around Washington D.C. and California. These regional concentrations of defence spending have been referred to as the "Gunbelts", 109

The result of these geographical concentrations is that military spending levels in the US are determined to a great extent by the military's geographical constituencies which are particularly sensitive to spending levels and have a

\footnotetext{
${ }^{108}$ Robert Atkinson, "Defence Spending Cuts and Regional Economic Impact: An Overview," Economic Geography, April 1993: 108.

${ }^{109}$ Robert Atkinson, "Defence Spending Cuts and Regional Economic Impact: An Overview," 114
} 
strong interest in lobbying for pro-military policies which will benefit their local economies. This is in contrast to military spending policy which is determined by the domestic, or international, economic climate. This deviation of the state's political economy serves to decouple even further, military spending policies from the crucial goal of effecting change on the aggregated American economy. Instead, military spending focuses on stimulating the 'Gunbelts', or even specific cities within them! ${ }^{110}$

The military also has strong socio-economic constituencies which exercise an undue influence on decisions of military spending. The most important economic constituencies for the military are monopoly capital and, somewhat surprisingly, organized labour, both of which absorb a disproportionate amount of military spending. To that end, military Keynesianism, '... appears to be employed in the interests of organized labour and monopoly capital, and not necessarily to offset stagnation or cyclical downturns in either the aggregate economy or the less influential sectors of capital and labour." 111 This is not to insinuate, as some authors have done, that military spending is little more than uncommonly sophisticated graft, because that would not be a fair representation of the situation. Instead of this military spending being 'Keynesian' in the classical sense of the word, military spending is rather employed more as a consistent subsidy for key economic and political constituencies perceived as fundamental to economic growth. Military spending in effect stimulates very specific sectors of the economy and acts as a Band-Aid for more systemic

\footnotetext{
${ }^{110}$ One particularly extreme example that was speculated upon in the literature was a particular 'Gunbelt' city where a base was relocated to a different neighbourhood in order to adjust traffic flow and reduce road congestion in advance of a tight electoral race. This was done under the auspices of a weakness of the base to terrorist attacks.

${ }^{111}$ J. L. Griffin et al, "The political economy of military spending: evidence from the United States," Cambridge Journal of Economics. 1982: 8
} 
political and social problems that cannot otherwise be addressed through the political process.

In this sense, military Keynesianism has perhaps been mis-labeled as it is not strictly 'Keynesian' per se; it is not a vessel of government expenditure used to increase the aggregate demand of an economy during a downturn. In fact, military spending is exceptionally ill-adapted to the ends of countercyclical spending. It is inflationary, especially when increased quickly; it contributes less to productivity than other types of government expenditure; and it crowds-out non-military government expenditures, such as social programs, which are better adapted for Keynesian stimulus. 'Military Keynesianism' is clearly a rather different animal than its civilian equivalent and yet it remains an important and well-used part of the domestic political-economic policy-toolbox. It's important to take note that these two 'Keynesianism', civilian public expenditures and military expenditures, have economic effects which are, in fact, in conflict with one another. 'The effect of non-military expenditure appears to be the opposite of military expenditure. While the latter generally helps produce stagnation, the former alleviates it. ${ }^{112}$

With all that said, there are un-serviced niches in the political economy of the state that are still in many ways best addressed by military spending; issues such as redistribution, government subsidy, localized stimulus, matters of statefederal jurisdiction and other thorny issues which prove equal parts necessary and contentious in the state system. Policies addressing these issues, and others

${ }^{112}$ Albert Szymanski, "Military Spending and Economic Stagnation,” 10. 
like them, continue to find their way into military budgets. Thus military spending will often perform the role of a pressure release valve of sorts, permitting political leaders to enact economic and social policies that are deemed necessary, yet potentially intolerable to the sensibilities of the public at large. As a result, a great deal of military spending tends to be clustered around the areas of public policy that are difficult politically to 'sell'. While the size and obvious economic inefficiency of the military budget makes it an easy target for criticism by outsiders, for elites it's difficult to not be tempted by the political utility of military spending. It is likewise difficult not to be horrified by the potential implications of ham-fisted budget cuts to the military and their potential to inadvertently disturb a delicately constructed relationship with the politicaleconomic order. As a result, military spending has proven particularly resistant to change with strong incentives for the maintenance of military expenditures that are embedded throughout the political decision-making process. 


\section{Chapter \#4}

\section{Military Innovation and Commercialization}

"Modern military technology is not advanced; it is decadent. Over the years, more and more resources have been spent on perfecting the military technology of a previous era. As a consequence, modern armaments have become increasingly remote from military and economic reality... they are incapable of achieving limited military objectives and they have successively eroded the economy. ${ }^{113,}$

-Mary Kaldor (Professor and Governor of Stockholm International Peace Research Institute)

Spinoffs of military research and development (R\&D) are one of the most common justifications for levels of military spending above what is strategically necessary to address the threat environment. In essence, the claim is that the research and development of technology for military use creates valuable inventions and spinoffs which ultimately earn back much of the initial development cost. An example of this might be, as mentioned earlier, the $18^{\text {th }}$ century development and employment of the cannon, which is responsible for much of the technological basis which allowed for the creation of the steam engine. ${ }^{114}$ More contemporary examples include the aeronautics and nuclear energy sectors which came into widespread use through major investments in military science conducted throughout the World Wars. ${ }^{115}$ These scientific breakthroughs are understood to have been pioneered by military science, although there is some question as to the causal relationship between military R\&D and scientific breakthroughs. 'Because military technology dominated (post-war) technology budgets and the activities

\footnotetext{
${ }^{113}$ Mary Kaldor, The Baroque Arsenal, (Ann Arbor: Andre Deutsch, 1982) 1

114 , It is worth recalling... that knowledge acquired in making weapons played an important role in the industrial revolution. James Watt turned to John Wilkinson, a canon-borer who had invented the only machine in all of England that could drill through a block of cast iron with accuracy, to bore the condensers for his steam engines.' (Vernon W. Ruttan, "Is War Necessary for Economic Growth? Military Procurement and Technology Development,")

${ }^{115}$ Vernon W. Ruttan, "Is War Necessary for Economic Growth?"
} 
of technology intensive companies, this had a powerful influence on the overall direction of technology. ${ }^{116}$ It is in this sense that military spending has guided the technological development in a certain direction, rather than having advanced according to the course of technological process that would have been chosen by innovators themselves. It is thus far from certain that military spending's effect on technological growth has been more constructive than would have been its absence.

Establishing clear tendencies that might govern this relationship between military spending and technological development with absolute certainty is a difficult matter. There is substantial difficulty in any valid cost-benefit analysis of military R\&D spending since it is nearly impossible to quantifiably relate spending to its outcome. ${ }^{117}$ Consider that while military originated advancements like the steam engine accrued an incredible expense $^{118}$, the benefit of the associated spinoffs is also incredible. Indeed, what type of reasonable estimation of economic and political value can be placed on breakthroughs in science and technology so revolutionary that they have heralded an entirely new politicaleconomic order? This is more than an abstract question; there is a hopeless inability to scientifically measure costs and outcomes even for individual military projects in the present-day. Returning to the example of Canada's F-35 fighter procurement, cost estimations range from $\$ 45.8$ billion to $\$ 126$ billion, ${ }^{119}$ or in other words, costs may be up

\footnotetext{
${ }^{116}$ Mary Kaldor, "Forward," In. Pianta, Mario. New Technologies Across the Atlantic: U.S. Leadership or European Autonomy? The United Nations University, (Tokyo: Harvester Wheatsheaf, 1988) xiii.

${ }^{117}$ A disproportionate share of the attempts to develop such a cost-benefit analysis occurred during the period 1970-1990 and was, in all likelihood, a function of the crisis in military spinoffs that is addressed at length later in this chapter. While it would be a grave mistake to discard this wealth of research, part of the risk of employing older references is the potential for over-extrapolating observations that might be historically contingent. Being fully aware of this possibility from the outset, this work has been cautious in its use of literature from the 1970s and 1980s, employing this evidence conservatively and only when there is a clear case for their continued relevance and applicability.

${ }^{118}$ With estimates for Britain's increased borrowing during the Napoleonic wars as an example being as high as $800 \%$ of the previous period. (Niall Ferguson, The Cash Nexus, 121.)

${ }^{119}$ Steven Chase. "F-35 costs at least $\$ 10$ billion higher than Ottawa estimates, expert says," The Globe and Mail April $28^{\text {th }}, 2014,<$ http://www.theglobeandmail.com/news/politics/f-35-costs-could-doubleover- programs-life-expert-says/article18325378/>.
} 
to $275 \%$ higher than the lowest estimate. To provide this with some character, the construction of Trafalgar Hospital in Oakville Ontario is estimated to cost \$2.7 billion. ${ }^{120}$ This means that the approximate cost-uncertainty of the F-35 procurement is around the value of 30 new state-of-the-art hospitals, an astronomic margin of error. Despite rare claims to the contrary, the consensus seems to be that the measurement of military R\&D spinoffs remains part and parcel of the contemporary obstacles to understanding military spending. ${ }^{121}$ Disagreements about the real outcomes and costs of military spending are often so fundamental that analysts and scholars do not share common ground about whether or not military spending has a positive or negative influence on technological development. To unpack this problem and attempt to gain an understanding of military spending's spinoff effects, it therefore becomes necessary to grapple with questions pertaining to the relationship between military R\&D spending and revolutionary technological breakthroughs.

\subsection{A Catalyst to Scientific Breakthroughs?}

\section{At first glance, the volume of scientific advancement associated with military}

R\&D seems to support the arguments in favour of military spending's economic value.

Indeed, few inventions would seem to have been as revolutionary as those which began

with a foundation in military science. Yet it does not follow that military R\&D has

\footnotetext{
${ }^{120}$ David Lea, “The new state-of-the-art Oakville Trafalgar Hospital will cost \$2.7 billion,” The IFP News. April $2^{\text {nd }}$, 2014, < http://m.theifp.ca/news-story/5372149-the-new-state-of-the-art-oakville-trafalgar- hospital-will-cost-2-7-bi/>.

${ }^{121}$ Proper cost-estimation is a recurring concern in the literature with few conclusive results or widely accepted methodologies for estimating costs. As described in a particularly lucid summary from the World Bank, 'It is surprising that the empirical literature, taken as a whole, yields an ambiguous answer to the question of whether military spending (cuts) has a positive impact on growth... our suspicion (is) that the ambiguous results of past studies may reflect weaknesses in estimation methodology, particularly the failure to exploit both the cross-section and time series dimensions of available data using appropriate econometric techniques.' (Malcolm Knight et al. "The Peace Dividend: Military Spending Cuts and Economic Growth,” The World Bank - International Monetary Fund. February 1996, 39.)
} 
necessarily been the direct cause of these scientific advancements. In terms of causality, the argument could be made, for example, that humanity was already on the cusp of discovering the science of nuclear energy in the 1940s and would have ultimately done so without the involvement of military research. ${ }^{122}$ However, with the necessities of war having conscripted the world's top scientific talent to military ends during this time, nuclear fission was forcibly discovered through military research because the military was circumstantially the employer of nuclear scientists. Historical counter-factual arguments such as these do not provide conclusive answers, although they do raise pressing questions about the basic assumptions underpinning the thesis of military spending as a catalyst to technological breakthrough.

Put simply, the fact that military R\&D has produced a certain scientific achievement is not clear evidence that it would have not otherwise been produced through civilian R\&D spending. 'Besides the individual interesting cases of civilian spinoffs... many of the products would have been developed anyway by the industry. ${ }^{123}$ Nor is it clear that military research would be more prone to produce revolutionary results than would an equivalent civilian effort. With that being said, there remains an undeniably strong association of large amounts of funding to military R\&D and countries with high of level technological advancement overall. This association is as good a starting point as any to explore the relationship of military R\&D with the rest of the political economy. In the United States, for instance, which is one of the world's foremost countries for technological research, military R\&D funding comprises 'a little

\footnotetext{
${ }^{122}$ Recalling the 1938 theoretical discovery of fission by Otto Hahn and Fritzstrassmann, it seems relatively unsurprising that the applied discovery of fission would eventually occur in 1945.

${ }^{123}$ Mario Pianta, New Technologies Across the Atlantic: U.S. Leadership or European Autonomy? The United Nations University, (Tokyo: Harvester Wheatsheaf, 1988) 84.
} 
over 50 percent of all federal R\&D fund(ing). ${ }^{124}$ Many argue that the two facts are related and that military $R \& D$ spearheads innovation in new fields in a way that private $\mathrm{R} \& \mathrm{D}$ does not.

There is some validity to this assertion since military R\&D is subject to very different risk valuations and capital constraints than its private sector equivalent. The nature of military R\&D is different, ' ... for a variety of institutional factors, the mode of financing, the absence of market mechanisms. ${ }^{125}$ Financial imperatives in the private sector tend to encourage investments in relatively low risk and short term avenues of $\mathrm{R} \& \mathrm{D}$. This is because these types of research are likely to produce an immediate pay-off and thus do not overburden a company's relatively small, when compared to that of government, balance sheet. This investment strategy is in contrast to military R\&D investment which is governed to a greater degree by non-financial, long term considerations, like developing a strategic advantage. The result is that military R\&D is encouraged to pursue the types of high risk, low yield avenues of research that are more likely to produce revolutionary results. Indeed, given the remarkable advantages bestowed on a military which has achieved a revolutionary technological breakthrough, ${ }^{126}$ the incentives governing military R\&D would seem to encourage revolutionary research.

With this strong association between military R\&D spending and technological breakthroughs, there is an appreciation among policy-makers that military R\&D represents, 'a significant de facto innovation policy...(and) one of the major, direct policy

\footnotetext{
${ }^{124}$ Andrew D James, "U.S. Defence R\&D Spending: An Analysis of the Impacts," $\underline{\text { Prest }}$, (University of Manchester, 2004) 10.

${ }^{125}$ Mario Pianta, New Technologies Across the Atlantic: U.S. Leadership or European Autonomy? The United Nations University, (Tokyo: Harvester Wheatsheaf, 1988) 64

${ }^{126}$ For an example, think to the Ottoman use of cannons on the walls of Constantinople in 1453 or to the 'Charge of the Polish Cavalry in the Second World War. A slight technological advantage can often permit decisive change in military fortunes.Mario Pianta, New Technologies Across the Atlantic: U.S. Leadership or European Autonomy? The United Nations University, (Tokyo: Harvester Wheatsheaf, 1988) 64
} 
channels through which the government can affect firms'. ${ }^{127}$ In the United States, for instance, '...in 1981, 71 percent of the $\$ 3.5$ billion spent by the US federal government of R\&D were distributed to the Defence Department, NASA and the military activities of the department of energy.' ${ }^{128}$ Of course, the proportion of the R\&D budget dedicated to military activity varies a great deal between countries and time periods, but its centrality to the $R \& D$ regime is relatively common. ${ }^{129}$ With that being said, this situation may not be ideal. While it may be necessary to accept that the expenditures associated with major scientific breakthroughs are seldom undertaken by the private sector, it does not necessarily follow that this type of spending must necessarily be enacted through the military budget. Besides being a public entity, there does not seem to be anything the military's mandate which precludes its disproportionate centrality to R\&D policy. Indeed, there is a strong inverse correlation between levels of military R\&D and other public sector industrial R\&D, which seems to indicate that they are mostly interchangeable. ${ }^{130}$

Furthermore, while military R\&D may be associated with many technological breakthroughs on the whole, this is not to say that all of military R\&D is directed towards so-called 'fundamental discovery' which enables breakthroughs. In fact, to use the United States as an example once again, 'development, testing and evaluation of weapons systems represents by far the largest share of the (R\&D) budget - almost $85 \%$. The Science and Technology program (conversely) accounts for a little over $15 \% .{ }^{131}$ Remaining sensitive to the inevitable differences of military R\&D's composition across

\footnotetext{
${ }^{127}$ Mirko Draca, "Reagan's Innovation Dividend? Technological Impacts of the 1980s US Defence BuildUp,” (Warwick: University of Warwick Press, September 2013) 29.

${ }^{128}$ Mario Pianta, New Technologies Across the Atlantic: U.S. Leadership or European Autonomy? The United Nations University, (Tokyo: Harvester Wheatsheaf, 1988) 71

${ }^{129}$ It should be noted that centralized innovation and R\&D policies feature much more prominently in the Post-War era than prior to it. Therefore, while the military tends to be a significant actor in R\&D policies, this phenomena must be noted to be relatively modern.

${ }^{130}$ Richard Nelson, "National Innovation Systems: A Retrospective on a Study,." Industrial and Corporate Change, 1992: 355.

${ }^{131}$ Andrew D James, "U.S. Defence R\&D Spending: An Analysis of the Impacts," 11.
} 
countries and timelines, it is nonetheless unsurprising to note that, with very few exceptions, military R\&D dedicates more energies to the innovation of weapon systems than general purpose technology. ${ }^{132}$ All told, only '...about 2\% (of total military R\&D spending), is to be spent on basic research which might be expected to further commercial technologies. Almost no commercial applications result from the development of particular weapons systems, only from basic research. ${ }^{133}$ In other words, the element of R\&D most associated with technological breakthroughs is not military science nor is it fundamentally a major component of military R\&D.

Why then is such a large share of public R\&D funding allotted to the military instead of elsewhere? Perhaps in a manner reminiscent of military spending's distributive tendencies outlined in the previous chapter, there continues to be a factor of political expediency which, ceteris paribus, edges long-term innovation expenditures under the umbrella of strategic military necessity. Certainly while 'a major part of governments' technology policy is developed for 'defence' purposes...the development of military technology represents also a form of industrial policy, supporting national firms in key sectors. ${ }^{134}$ This disassociation from its direct and measurable outputs and emphasis on maximizing long R\&D projects may be part and parcel of military R\&D's tendency for cost-overruns and for producing underwhelming end-products. Although difficult to conclude with total certainty, the incentive structure governing military R\&D seems to be unintentionally pushing for these exact results; reducing emphasis on results and transparency while encouraging uncertain avenues of technological development. Although this incentive structure may ultimately produce some advantages in

\footnotetext{
${ }^{132}$ Indeed, a result other than this would seem to be indicative of institutional disfunctionality, agentprinciple dilemmas or political capture.

${ }^{133}$ R McKenna, "Technology and Freedom," Paper for the Conference of Business Executives for National Security. January $29^{\text {th }}, 1986: 7$.

${ }^{134}$ Mario Pianta, New Technologies Across the Atlantic: U.S. Leadership or European Autonomy? 64
} 
technological spinoffs, it is important to ponder whether this by-product outweighs the additional costs created for military goods. Once again, the major analytical obstacle to a comparative cost-benefit analysis is the lack of transparent and quantitative data. Yet it is clear that the association between military spending and technological breakthroughs is not an indication of the military's supposedly inherent superiority in bridging technological breakthroughs.

\subsection{Spinoffs}

This is not to dislodge military spending from its important space within R\&D spending ecosystem, since it nonetheless does produce spinoff technologies and goods which require some sort of valuation. While perhaps military R\&D spending cannot be ascribed special characteristics which enable better results in producing technological breakthroughs, there remains a strong association between military R\&D and valuable downstream technological spinoffs that cannot be ignored. For example, some have noted a relationship between commercial dominance and high levels of military procurement in the same field, using this relationship to justify the value of military R\&D's spinoffs benefits.

'Of the major industrialized nations, the US spends by far the largest share of industrial R\&D on military projects. A strong case can be made that in the 1960s this helped the American electronics and aircraft industries to come to dominate commercial markets. ${ }^{135}$

In examples like these, it is important to parcel out the variable effects of military involvement according to whether they fundamentally represent effects inherent to

\footnotetext{
${ }^{135}$ Richard Nelson, "National Innovation Systems: A Retrospective on a Study,." Industrial and Corporate Change, 1992: 362
} 
military spending in $\mathrm{R} \& \mathrm{D}$, or whether they represent another variable altogether. In the commonly cited example of American military and industrial production of aircraft and electronics, it would be unwise to draw wider conclusions about the core nature of military R\&D spending, as this seems to represent a clear cut-case of defence procurement pull rather than an underlying tendency for greater military R\&D spinoffs. Voluminous military procurement essentially creates a safe harbour for firms in a turbulent new market, reducing risk by providing relatively secure profits while domestic actors scale up their operations. ${ }^{136}$ Put otherwise, 'the high-tech nature of defence procurement sales could (be used to) push out the 'innovation possibilities frontier' as firms commit their resources to more technically ambitious projects than those demanded by the civilian sector. ${ }^{137}$ Rather than being a true representation of spinoffs inherent to military R\&D, this effect would be more accurately understood as subsidization of 'infant industries' and $R \& D$ via military processes.

'Thus, (the United States Department of Defense)'s willingness in the 1960s to pay almost any price for compact, lightweight electronics for its missile programs stimulated the infant semiconductor industry. The early and cost intensive purchasing helped companies pioneering the technology to move down the learning curve, reducing their costs to a point where commercial customers could afford the new chips. ${ }^{138}$

The important question then becomes whether this subsidization of 'infant industries' through military spending primarily represents an innocent spinoff by-product, or an intentional abuse of political channels. Subsidization via government procurement has been a long-standing issue for global trade regulators such as the World Trade

\footnotetext{
${ }^{136}$ Andrew D James, "U.S. Defence R\&D Spending: An Analysis of the Impacts," 37.

${ }^{137}$ Mirko Draca, "Reagan's Innovation Dividend? Technological Impacts of the 1980s US Defence BuildUp" 3.

${ }^{138}$ Ibid.
} 
Organization (WTO), which seek to enforce a level playing field in international trade and prevent undue government subsidies. The WTO's 1994 Agreement on Government Procurement (AGP) spells out the rules for conducting government procurement in a manner that does not constitute an industrial subsidy, and interestingly, military procurements are exempt from the AGP's standards. ${ }^{139}$ This fact incentivizes policymakers to use military procurement as a vehicle for subsidy since military spending does not represent a violation of trade agreements and thus should not be taken as evidence that military spending is a particularly cost-effective vehicle of industrial or R\&D subsidy. ${ }^{140}$

Alternatively, there is an argument to be made that military procurement may actually have negative effects on R\&D and technological spinoffs. Firstly, there is always the danger that subsidies will inhibit productivity growth, with firms ultimately aiming to attract subsidies rather than generate profits. This may be especially true for military industries, where '...many are skeptical about the ability of the state to distinguish real infant industries from rent-seeking geriatrics. ${ }^{141}$ There are other unintended effects of military procurement for industrial purposes, including that '...the concentration of

\footnotetext{
139 "Subsidies through Government Procurement". Global Subsidies Initiative. International Institute for Sustainable Development. December $8^{\text {th }}, 2014 .<$ http://www.iisd.org/gsi/subsidy-types $>$.

${ }^{140}$ Since military procurements are exempt from the AGP, it is difficult to measure with certainty the level of subsidization that is conducted through military procurement. Although unquantified there is nonetheless strong evidence of its widespread existence. Not the least of which being the multitude of trade disputes arising between EU countries (which spend proportionately little on military procurement and R\&D) and the United States (which spends proportionately high levels on military procurement and R\&D) in military sensitive industries. These wide ranging and long-standing trade disputes routinely involve accusations of military subsidization on the part of the United States. (Andrew D. James, "U.S. Defence R\&D Spending: An Analysis of the Impacts," 34-35.)

${ }^{141}$ Ron Smith, Military Economics: The Interaction of Power and Money, 33. Since military procurements are exempt from the AGP, it is difficult to measure with certainty the level of subsidization that is conducted through military procurement. Although unquantified there is nonetheless strong evidence of its widespread existence. Not the least of which being the multitude of trade disputes arising between EU countries (which spend proportionately little on military procurement and R\&D) and the United States (which spends proportionately high levels on military procurement and R\&D) in military sensitive industries. These wide ranging and long-standing trade disputes routinely involve accusations of military subsidization on the part of the United States. (Andrew D. James, "U.S. Defence R\&D Spending: An Analysis of the Impacts," 34-35.)
} 
innovative activities in military projects diverts resources for the development of commercial technologies and increases the competition for limited resources in R\&D funds, scientists, laboratories and specialized plants... (causing a) military drain on... innovative activities. ${ }^{142}$. Especially during the Cold War, it was very popular in intellectual circles to speak of defense spending 'crowding out' more productive avenues of $R \& D$ and investment. ${ }^{143}$ The core argument is that since 'the military sector must attract workers and equipment from civilian industries by offering to pay higher prices or wages...(this cost) must be rationed off with price increases for military output and also for civilian goods produced by these same industries. ${ }^{144}$ The effect is escalating costs for $R \& D$ in sectors where the military is a substantial actor and commensurate decreases in overall technological progress.

As an example, there existed a strong correlation between highly concentrated American military procurement of electronics in the 1970s and 1980s and the decline of global American leadership in the consumer electronics industry. This decline was supposedly attributed, in large part, to the incentives produced by military R\&D spending, which diverted R\&D development away from more productive avenues of research to military projects. ${ }^{145}$ Beyond the crowding out effect, it has been suggested that the particularities of military equipment severely limit the applicability of R\&D spinoffs, since 'extreme design sophistication and strong centralization of control over production are key characteristics of military-oriented technological development... (which) limit the applicability of its results to civilian industry. ${ }^{146}$ While we tend to

\footnotetext{
${ }^{142}$ Mario Pianta, New Technologies Across the Atlantic: U.S. Leadership or European Autonomy? 81.Ron Smith, Military Economics: The Interaction of Power and Money, 33

${ }^{143}$ Andrew D. James, "U.S. Defence R\&D Mario Pianta, New Technologies Across the Atlantic: U.S. Leadership or European Autonomy? 81.

${ }^{144}$ Olof Palme, et al. "Military Spending: The Economic and Social Consequences" 12. Spending: An Analysis of the Impacts" 36.

${ }^{145}$ Ibid

${ }^{146}$ Mario Pianta, New Technologies Across the Atlantic: U.S. Leadership or European Autonomy? 87.
} 
remember the technologies that have successfully spun-off from military R\&D, we easily forget the alarming degree of failure among military R\&D spinoffs.

'The case of nuclear power is an example of a highly unsuccessful technology on commercial terms that was developed from military research on nuclear weapons... U.S. Nuclear reactors were developed after a strong R\&D effort by the U.S. Navy, without exploring alternative designs and without competitive mechanisms...(leading arguably) to the (commercial) failure of the industry... The case of supersonic aviation is another example of the (unsuccessful) attempts to use in civilian areas possible spin-offs from the development of military supersonic aircraft. ${ }^{147}$

The repeated inability of the military to produce commercial successes has led many to conclude that, '...the indiscriminate pursuit of military spillovers (spin-offs) thus turned out to be a recipe for commercial disaster. ${ }^{148}$ Some have even suggested that this distortion of research priorities caused by high levels of military R\&D spending hinders overall economic growth over the long-term. ${ }^{149}$ While such a bold generalization must be handled cautiously, there is nonetheless very real concern about the distortion caused by military R\&D spending, particularly when considering its interaction with so called 'long-waves' ${ }^{150}$ of innovation. As expressed in an example by Mary Kaldor,

'The industrial base for the modern armament sector was created in

147 Ibid. 82-85 Mario Pianta, New Technologies Across the Atlantic: U.S. Leadership or European Autonomy? 87.

${ }^{148} \mathrm{~N}$ Rosenburg, Civilian 'Spillovers' from Military R and D Spending: The American Experience Since World War II, (Stanford: Stanford University, 1986) 24.

${ }^{149}$ Albert Szymanski, "Military Spending and Economic Stagnation," 7. N Rosenburg, Civilian 'Spillovers' from Military R and D Spending: The American Experience Since World War II, (Stanford: Stanford University, 1986) 24.

${ }^{150}$ Also sometimes known as 'Kondratiev Waves', this term signifies the idea that innovation occurs in cyclical 50 year waves. While first observed by Nikolai Kondratiev in The Major Economic Cycles (1925), the concept also features heavily in the work of Joseph Schumpeter and his predecessors. Albert Szymanski, "Military Spending and Economic Stagnation," 7. 
World War II. It consisted of the dominant companies of the period, mainly the manufacturers of automobiles and aircraft. By maintaining and expanding this base, military spending has helped to preserve the industrial structure of the 1940s... (This spending) artificially expands industries that would otherwise have contracted. It absorbs resources that might otherwise have been used for investment and innovation in newer, more dynamic industries. And it distorts concepts of what constitutes technical advance, emphasizing elaborate custom-built productive improvements that are typical of industries on the decline instead of the simpler, mass-market process improvements which tend to characterize industries in their prime. ${ }^{151}$

There is thus, to say the least, a clear lack of sufficient empirical evidence to support the thesis that military R\&D spinoffs are by their very nature more efficient than those of civilian industry.

Nonetheless, the popular myth persists that military science is pre-disposed to more economic R\&D spinoffs than its civilian counterpart. Part of the reason for this is related to the most pronounced procedural difference between military and civilian R\&D: that of secrecy. With most military R\&D being required out of strategic necessity to retain an element of secrecy, an unintentional consequence is that the costs and stumbles of military R\&D are similarly masked by secrecy in such a way that most civilian R\&D is not. This makes the attribution of costs and visibility of scientific setbacks markedly more apparent in civilian research than in military research. Similarly, the setbacks and costs associated with military science often remain classified for many years due to strategic concerns, giving the appearance that military R\&D often results in successful

${ }^{151}$ Mary Kaldor, The Baroque Arsenal, 5. 
and timely scientific advances while disguising its failures. As one commentator noted, 'Advanced research, by its very nature, produces more failures than successes. The only time this becomes a problem, though, is when those failures see the light of day' ${ }^{152}$ which results in a major public relations advantage for military R\&D. Even though the element of secrecy may contribute to the positive image of military R\&D, a closer examination of secrecy's effects on R\&D reveals that this supposed contributor to military R\&D's superiority may in fact detract from its effectiveness.

There is a great deal of evidence which raises serious doubts that secrecy is helpful to the scientific process and ultimate production of an economic spinoff benefit. This basic military prerequisite results in starkly different structural and procedural differences in how military and civilian R\&D is conducted, with 'military science requir(ing) qualities - secrecy and the isolation of scientists - which are not necessarily favourable to civilian research, (n)or to the civilian diffusion of discoveries ${ }^{153}$ This would seem to suggest that, all other things held equal, military R\&D is pre-disposed to lesser efficiency at producing research of all kinds than its civilian counter-part. When looking to military R\&D's overall effect on civilian R\&D, 'the benefits to civilian technology seem decidedly less than if the funds were spent directly on civilian technology. ${ }^{154}$ This would seems intuitively correct given that the volume and depth of innovation stems from the degree of 'collective learning which (itself) depends on the number of potential innovators and the closeness or connectivity between them. ${ }^{155}$ Thus increasing the barriers to collective learning by preventing scientists' ability to

\footnotetext{
${ }^{152}$ Andrew D. James, "U.S. Defence R\&D Spending: An Analysis of the Impacts," 28.

${ }^{153}$ Olof Palme et al. "Military Spending: The Economic and Social Consequences," 14.

${ }^{154}$ Edwin Mansfield, "Technology and Productivity in the United States." The American Economy in Transition. Ed, Martin Feldstien, (Chicago: University of Chicago Press, 1980) 589.

${ }^{155}$ John Green and Hank Green, "Migrations and Intensification." Crash Course. Youtube. November $26^{\text {th }}$, 2014. December $9^{\text {th }}, 2014$. $<$ https://www.youtube.com/watch? $==$ Oy2XJMczUNc $>$.
} 
collaborate should decrease innovative output. Scientists themselves would seem to concur with this assessment, with a broad survey of scientists employed in field of military R\&D arguing that, '(good) science and war (are) antithetical to each other.'156 This may be an especially modern feature of military R\&D, as

'the pace of commercial technology development in areas such as electronics, advanced computing, communications and medical research (those of primary interest to the military) far outstrips anything (possible) within the defence R\&D system.' ${ }^{157}$

The result would seem to be that the nature of current technological development may be particularly non-conducive to military involvement. Regardless of the degree, if scientific progress and military technologies are indeed such strange bedfellows, how has public opinion consistently come to the opposite conclusion about the nature of military R\&D spinoffs?

\subsection{The Root of the Myth}

At its core, much of the mythology surrounding the nature of military R\&D has historically situated origins that stem from the major scientific advances which occurred during, and immediately preceding, major conflicts. While there are many obstacles to a measured cost-benefit estimation of spinoffs from military $R \& D,{ }^{158}$ one important

\footnotetext{
${ }^{156}$ D.E.H. Edgerton, "British Scientific Intellectuals and the Relations of Science, Technology and War" Boston Studies in the Philosophy of Science. 1996: 2.

${ }^{157}$ Andrew D James, "U.S. Defence R\&D Spending: An Analysis of the Impacts," 29.

${ }^{158}$ Another amongst many would be a lack of comparable statistical data for spending and national accounts. It is worth noting that prior to the interwar years, there were only rudimentary and unstandardized systems for estimating the national wealth, with the practice of regular annual national budgeting first beginning to take off during this time. It was only, 'After World War (that) government statistical offices supplanted (individual) economists and began to compile and publish official annual data on GDP and national income'. (Thomas Piketty, Capital in the Twenty-First Century, (Cambridge: Harvard University Press, 2014) 57.) This would have made the task of properly estimating the costs of the Second World War in relation to the spinoffs an even more insurmountable task, undoubtedly contributing to the absence of reliable data.
} 
variable to consider is that the costs of large-scale war are deeply elusive to estimation, making it especially difficult to give an appraisal of military R\&D's costs during wartime. Unlike estimates of peacetime military expenditures, which on their own can prove rather elusive $^{159}$, many of the costs incurred during major war efforts fall far outside of standard accounting practices. Employing the (rather large) assumption that official government figures from periods of conflict are accurate ${ }^{160}$, they still do not include indirect costs such as inflation. These indirect costs are usually borne by the public at large, with rapid inflation for instance degrading private savings, skewing consumption patterns, and stunting future productivity.

Furthermore, there is little consideration for foregone investment opportunity costs and the distortion of research priorities that occurs in major wars. In other words, it is very difficult to compare the value of existing technological advances to those which never occurred as a consequence of research re-prioritization due to conflict. ${ }^{161}$ Said otherwise, while there may have been substantial advances made as a result of military $\mathrm{R} \& \mathrm{D}$ during war-time, it is impossible to know for certain about the technological advancements which did not occur due to the unavailability of capital for private invention and, therefore, equally impossible to judge the opportunity cost. It must ultimately remain a mystery whether a civilian or military R\&D trajectory would have

\footnotetext{
${ }^{159}$ As an example, in estimating military expenditure differences arise in, 'the time period over which the costs are measured and what is included in the costs. In addition to the direct costs... one may or may not include things such as: replacement military equipment; extra interest on the national debt; the risk premium added to (commodity) prices; the future costs of medical care for those wounded; and inputted values of human lives for those killed.' (Ron Smith, Military Economics: The Interaction of Power and Money, 31.) "There (also) are variations in the treatment of the intelligence services, the paramilitary forces like the Gendarmerie in France and the Guardia Civil in Spain; nuclear or space research which has civil and military applications; and pensions of retired members of the armed forces. Definitional differences can be large and cause differences between sources even within one country.' (Ron Smith, Military Economics: The Interaction of Power and Money, 90, )

${ }^{\frac{T}{160}}$ A very large assumption considering the variation in accounting practices, estimates and all of the other difficulties associated with estimating historically rooted government expenditures.
}

${ }^{161}$ Andrew D. James, "U.S. Defence R\&D Spending: An Analysis of the Impacts.," 35-37. 
ultimately yielded the more impressive end-result.

There are also important elements of $R \& D$ advancements made in wartime that typically fall outside of the cost-benefit analysis due to considerations pertaining to international relations and geo-politics. During the Second World War, for instance, a great deal of the technological progress which occurred was spear-headed by Axis military institutions, specifically those of Germany. While many Post-War military spinoffs should be attributed to German R\&D expenditures, for the most part these spinoffs were ascribed to the victors who did not accrue the associated R\&D costs. For example, the German Messerschmitt Me 262 was the world's first jet aircraft. Its designs and prototypes were captured at the close of the war and the next generation of Allied aircraft heavily incorporated features of their jet engines. ${ }^{162}$ There was much similar technological pillage during the Second World War which served to inflate the R\&D benefits associated with Allied military spending from that time without consideration for the costs incurred by the Axis. ${ }^{163}$ Nor are the human costs associated with German military research included, an important consideration since much of the wealth of research and rapid technological advancements accumulated during the Second World War was only possible as a result of human experimentation and concentration camps. ${ }^{164}$ This makes it difficult to establish a clear relationship between military R\&D in

\footnotetext{
${ }^{162}$ Walter J. Boyne, Clash of Wings: World War II in the Air, (New York: Simon and Schuster, 1994) 320-328.

${ }^{163}$ Another aspect of this that bears consideration is Operation Paperclip, an American effort to attract and employ Axis scientists and engineers, mostly from Germany, following the close of the Second World War. Many of these researchers had been employed by the Nazi party in the field of military R\&D and went on to re-employ the skills and research advancements they achieved during the Nazi regime to advance military R\&D projects in the United States. This included the uncomfortable fact that many of the top NASA scientists shared affiliations with Operation Paperclip. (for more see, Annie Jacobsen, Operation Paperclip: The Secret Intelligence Program that Brought Nazi Scientists to America, (New York: Little Brown, 2014). )

${ }^{164}$ One particularly illustrative example would be of flight-suits for pilots by the Luftwaffe. Various designs were tested to reduce the effects of enhanced gravity experienced by pilots and to increase the survivability for those who had been shot down over cold ocean waters. This was done through gruesome human experimentation including the testing of suits on the prisoners of concentration camps who would be submerged in cold water while wearing various suit designs to see how long they would
} 
the Second World War and the scientific advances that were claimed on its behalf. Rectifying this would be an important first step in achieving an accurate estimate of many of the Second World War's R\&D spinoffs. However, even if the victors of the Second World War wished to give credit to the inventions arising from the German military's R\&D efforts, the intentional and unintentional destruction of records at the fall of the Nazi regime would likely have made this quite impossible.

With all of this in mind, it is no surprise that the Second World War would be a catalytic moment in the debate around military spinoffs and especially those spinoffs pertinent to $\mathrm{R} \& \mathrm{D}$, with policy-makers and the public alike trying to make sense of the conflict's huge costs in money and human life. As a result, '(While) the discussion on spin-offs dates from before World War I... it was not until the escalation of military R\&D after World War II when (spinoffs) became commonplace in political discussions. The spin-off argument often appears as a complementary reasoning to justify growing military expenditure. As the definition of external threat and its magnitude are not universally accepted...the spinoff argument offers a further rationale to convince the public about the merits of military expenditure...point(ing) out that many important technological advances in the civilian area have been have been introduced because of military R\&D. ${ }^{165}$

live depending on the design.

Robert Berger, "Nazi Science - The Dachau Hypothermia Experiments." The New England Journal of Medicine, 1990:1435-1436.

Not only would a financialization of the loss of life during the Second World War and an estimation of its value to research prove immensely difficult, it would also be morally objectionable. This point has been a source of controversy for researchers to the present-day with many ongoing debates about the value and moral dilemmas surrounding the incorporation of Nazi human experimentation into the existing body of scientific research.

${ }^{165}$ Jordi Molas-Gallart, Military Production and Innovation in Spain, (Philadelphia: Harwood Academic Publishers, 1992) 21. 
Given the sheer amount of potential for R\&D spin-offs from military science that were present immediately following the Second World War, intellectual and political elites had a ready-made justification for the high levels of military expenditure deemed necessary to meet the challenges of the Cold War. Yet it is worth making a careful chronological distinction ${ }^{166}$ between the civilian R\&D spinoffs that were emerging in commercial industry, and the Cold War military expenditure that this was used to justify. Indeed, the majority of R\&D spinoffs heralded as a justification for high levels of military expenditure in the 1950s and 1960s were technological advancements that stemmed not from Cold War spending, but rather stemmed from the spending incurred during the Second World War two decades earlier.

In other words, much of the military R\&D spending of the 1950s and 1960s is mistakenly associated with the R\&D spinoffs of the 1930s and 1940s. This is due in part to perfectly normal delays in technological implementation, since 'military systems need 15 to 20 years from technology assessment to operational deployment'. ${ }^{167}$ The result is that military advancements from the Second World War would become public knowledge only gradually and in subsequent decades. Due to this delay, which was further aggravated as these advancements required additional time to be adopted to consumer applications, technological spinoffs would not be associated with the enormous costs of the Second World War but with the (substantially lower) levels of military expenditure occurring during the Cold War. The result was the beginnings of a powerful myth that the natural character of military $\mathrm{R} \& \mathrm{D}$ spending would produce much more impressive results

\footnotetext{
${ }^{166}$ With the concept of 'spinoffs' only achieving wide prominence after they were accrued through the R\&D spending of Second World War, it is worth turning again to Piketty, '...national accounts are a social construct in perpetual evolution. They always reflect the preoccupations of the era when they were conceived.' (Thomas Piketty, Capital in the Twenty-First Century, 57.) Thus given that the pre-occupation with spinoffs post-dated any concern about their existence during the war itself, it seems to be of little surprise that the data necessary to estimate their value was not collected.

167 "Star 21 Strategic Aerospace Review for the $21^{\text {st }}$ Century". European Commission. July 2002. pg 30
} 
than an equivalent amount of civilian spending. Many fell victim to this mistaken association and there was great puzzlement when, starting in, 'the late 1960s there (was) little "(R\&D) spillover" 168 when compared to earlier trends. In hindsight, it is clear that the military R\&D spin-offs immediately following the Second World War were exceptional and unsustainable:

'the large spillover from the defense and space programmes of the late 1950s and 1960s was the product of a rather special set of circumstances... (while difficult to estimate with certainty) Many analysts have suggested that spillover has diminished markedly since the mid-1960s'. ${ }^{169}$

In this sense, the modern conception of R\&D spinoffs and their value was marred by a deep-seated misconception of cause and effect from the earliest beginnings. While certainly there were those who were able to recognize this at the time, the introduction of this idea into the mainstream has tainted the discourse that followed.

\subsection{Early Iconoclasm}

As the wellspring of R\&D spinoffs from the Second World War began to run dry, levels of military spending started to become visibly disassociated with the R\&D spinoffs that had come to be expected from military spending. Indeed, it became difficult to justify such high levels of military spending in (mostly) peace-time when their spinoff value seemed to be in such rapid decline. This resulted in a frank reassessment of the military's role and relationship with the economy, beginning in the early 1960s. Although one in many voices, U.S. President Eisenhower presented a particularly memorable critique of

\footnotetext{
${ }^{168}$ Richard Nelson, "National Innovation Systems: A Retrospective on a Study," Industrial and Corporate Change, 1992: 362.

${ }^{169}$ Richard Nelson, High Technology Policies: A Five-Nations Comparison, (Washington D.C.: American Enterprise Institute, 1984) 72.
} 
the relationship between the military and the economy at large in his 1961 Farewell Address. ${ }^{170}$ Eisenhower believed that the relationships formed between the military establishment, political elites and industry during the Second World War had resulted in economic and regulatory capture by the military. This situation, he argued, consistently produced and justified a suboptimal relationship between the military and the rest of the state's political economy as a whole. In Eisenhower's own words,

'When the (Second World) war was over, industries that had sprung up...adapted their products to service the postwar movement (leading) to the perpetuation of the wartime economy... defence products were simply refitted to serve post-war civilian uses...making defense development seem indispensable... (and) diverting an ever-increasing disproportion of national resources from vital areas of national need...to the military.' ${ }^{171}$

This, Eisenhower argued, represented a serious systemic risk that unwarranted military spending would continue, regardless of the security environment or real legitimacy of economic spinoffs of military spending. More specific to R\&D, Eisenhower stated that,

'Today, the solitary inventor, tinkering in his shop, has been overshadowed by task forces of scientists in laboratories and testing fields. In the same fashion, the free university, historically the fountainhead of free ideas and scientific discovery, has experienced a revolution in the conduct of research... The prospect of domination of the nation's scholars by Federal employment, project allocations, and

\footnotetext{
${ }^{170}$ It was during this speech that Eisenhower minted the now widespread term, 'military-industrial complex'

${ }^{171}$ Eugene Jarecki, The American Way of War, (Toronto: Free Press, 2008)
} 
the power of money is ever present - and is gravely to be regarded. ${ }^{172}$

Eisenhower and others called for an overall reassessment of military spending to counter the economic and political dangers of high military spending; however, the associations between military R\&D and valuable civilian spin-offs were not undone. Instead, overall levels of military spending, at least when taken as a portion of GDP, remained relatively steady.

From the post-war years onward, the share of military spending dedicated to equipment and R\&D steadily increased its share of the military budget through to the 1980s. ${ }^{173}$ The impetus for this change stemmed from a revolution in nature of warfare, which now demanded increased expenditures on non-conventional weapons, specifically as nuclear arms. This was related to a similar revolution in military economics with the realization that 'nuclear and conventional weapons can be substitutes: (with) the rising costs of conventional weapons provid(ing) incentives to switch to cheaper nuclear substitutes. ${ }^{174}$ Military R\&D would follow suit, with much of military science at the time retooling to focus on nuclear energy and the rocketry necessary to deliver nuclear payloads. Nuclear weapons were the cause of cataclysmic change across all spectrums of military affairs, one of the most fundamental of which was the newfound desire to avoid actually using military assets. Bernard Brodie, writing in 1946 about the implications of nuclear weapons for the nature of war and the military said, 'thus far the chief purpose of our military establishment has been to win wars. From now on its chief purpose must be to avoid them. ${ }^{175}$ Alternately, as expressed by Gwynne Dyer, perhaps with less subtly, 'if all the Great Powers were to go to war with one another just once more, using all the

\footnotetext{
${ }^{172}$ Dwight D. Eisenhower, "Farewell Address by President Dwight D Eisenhower", Public Papers of the Presidents, 1960: 1035-1040.

${ }^{173}$ John Treddenick. "The Arms Race and Military Keynesianism," 82-83.

${ }^{174}$ Ron Smith, Military Economics: The Interaction of Power and Money, 34.

${ }^{175}$ Bernard Brodie, The Absolute Weapon, (New York: Harcourt, Brace, 1946) 76.
} 
weapons they now have, a million people could die each minute. ${ }^{176}$ In other words, the costs of war began to steeply outweigh the potential benefit of victory.

This realization was the cause of a steep and immediate reduction in the amount of interstate war in parallel with increases in nuclear proliferation. ${ }^{177}$ With a near simultaneous drop-off in interstate war and spinoffs from military R\&D, the expectation might be for a reassessment of military spending policies and overall levels. Surprisingly, while 'military power (was) becoming less effective in achieving decisive and politically satisfactory results' ${ }^{178}$ there was no commensurate reassessment of military spending's R\&D spinoff value. While there had been a steep drop-off in the commercial spinoffs of military R\&D by the late 1960 s, as well as a rising inability to use military equipment in theatre, the now elusive nature of military products and by-products served to obscure this drop-off. Indeed, with the nuclear arms race being the primary procurement and R\&D thrust of the era, a large share of the military technology of the day would be literally buried underground and the civilian use of its R\&D spinoffs heavily restricted. ${ }^{179}$

At the same time that the Cold War R\&D thrust of military expenditure kept commercial spinoffs from public consumption, it also set in motion what was perhaps the most spectacular military R\&D spinoff of all time; the televised space race. ${ }^{180}$ Instead of seeking to measure the R\&D spinoff value of ICBMs and rocketry for space exploration, a dubious feat itself ${ }^{181}$, it is worth simply noting that the space race was, to that point,

\footnotetext{
${ }^{176}$ Dyer, Gwynne. "War.” Toronto: Random House, 1985. pg 5

${ }^{177}$ For more see, Kenneth Waltz, The Spread of Nuclear Weapons: More May be Better, (London: International Institute for Strategic Studies, 1981)

${ }^{178}$ Gwynne Dyer, War, 292.

${ }^{179}$ What civilian adoption of nuclear science did occur was almost universally limited to governments, or heavily regulated monopolies. Similarly, rocketry and space travel have only become a realistic endeavor for private citizens and companies in the 2000s, nearly 50 years after first manmade satellite was launched into orbit.

${ }^{180}$ Andrew Chaikin, "Live from the Moon: The Societal Impact of Apollo," The Societal Impact of

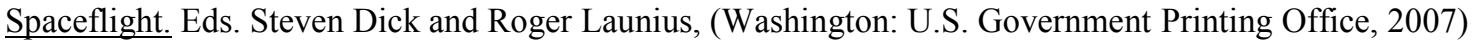
54.

${ }^{181}$ It is a dubious analysis not only due to the technology's spectacularly revolutionary nature but also since the possibilities (both commercial and otherwise) are still very far from being realized.
} 
unprecedented in how it brought intangible military spinoffs into people's homes and television sets, ascribing an ethereal value to military $R \& D$ spinoffs that might otherwise have gone unnoticed to the average person. The impact of this was a continuing mystification of the relationship between military R\&D inputs and tangible consumer good outputs as the newfound spectacularity of communications technology filled the gap between expectations and reality, continuing the obstruction of a clear cost-benefit analysis of military R\&D. The now nearly 50 year old public mythology surrounding military R\&D spinoffs would survive another day.

The end of the Cold War and the decreased threat environment that came with the dissolution of the Soviet Union would ultimately be matched by lower levels of military spending. Indeed, 'between 1986 and 1999 it is estimated that global military expenditures dropped by about a third, while procurement spending on weapons and employment in the arms industry halved. ${ }^{\prime 182}$ Naturally, one of the major intellectual discussions which emerged at the time was how to spend this newfound 'peace dividend ${ }^{183}$ which by most measures, never substantially materialized. Given the role of military spending in underpinning the state functions outlined in Chapter \#3, this might not be a surprise. As these difficult to perform functions of statehood already have a tendency to find their way into military budgets, it would make sense that these functions would not be outright eliminated with budget cuts to the military, but would rather migrate elsewhere in the state's budget. In other words, a cut to the military budget would yield a less than equivalent amount of savings because there is an extra social cost to cutting the military budget that must be recouped elsewhere. For instance, accepting that the military tends to employ groups that are statistically at higher risk of

\footnotetext{
${ }^{182}$ Ron Smith, Military Economics: The Interaction of Power and Money, 89.

${ }^{183}$ The additional money that would become available to public use due to a more peaceful international climate requiring a smaller share of the public coffer being devoted to defence.
} 
unemployment, taking soldiers off of the state payroll should result in more use of unemployment insurance than would occur when say, doctors, are laid-off. This means that reductions to military spending, compared to other types of spending cuts, should disproportionately raise the amount of money paid out by the state through other avenues.

In a way it seems as though the Post-Cold War budget cuts reinforced the productive military spinoffs myth. Indeed, it is a deceptively intuitive conclusion to reach given all of the evidence. If a given reduction in military spending was to result in a lesser than equal decrease in spending on the state's balance sheet, then the economic effect of military spending must be greater than the sum of its parts. Relying on assumptions like this led some observers to conclude that military spending must provide a boost to economic performance. Of course, this connection is illusory, with an overreliance on aggregate data at the expense of nuances in the military budget being rather dubious, to say the least. Yet the very opportunity for controversy at this sensitive time for the military sparked a fierce debate about the precise economic effects of military spending. Rather than to contribute to a demystification of military spending, this controversy served to obstruct an understanding of military spending's economic real effects.

This was exacerbated as it became politically expedient to engage in and perpetuate the myth. Those favouring high levels of military spending could argue for the merits of spinoffs, while others could argue for high levels of expenditure elsewhere in the civilian budget to compensate for reduced spinoffs arising from military budget cuts. These debates gained a momentum of their own and resulted in the adoption of some fundamentally bad policies as decision makers become converts to the cargo cult of military R\&D spinoffs. This is perhaps best represented by the Clinton administration's 
short-lived emphasis on 'dual-use' (military and civilian) R\&D funding, a program which had the intention of unlocking the maximum potential of military R\&D spinoffs. Initially launched in 1992, this program sought to consolidate military and commercial technological research in order to maximize R\&D spinoffs from the military. After a string of failures, it was quietly retracted in $1995 .{ }^{184}$ These attitudes continue to afflict the public debate today with the potential for R\&D spinoffs from the military remaining a central focus of conversations of military spending, despite being flawed and comparatively uncompetitive. Instead of the past eighty years offering a reflective and corrective examination of the role of the military $\mathrm{R} \& \mathrm{D}$, they have perhaps resulted in even more confusion.

${ }^{184}$ Andrew D. James, "U.S. Defence R\&D Spending: An Analysis of the Impacts" 7-10. 


\section{Chapter \#5}

\section{Military Training and Human Capital: The Soldier and Society}

'There is nothing training cannot do. Nothing is above its reach or below it. It can turn bad morals to good, good morals to bad; it can destroy principles, it can recreate them; it can debase angels to men and lift men to angels. And it can do any of these miracles in a year - even six months. ${ }^{185}$

Mark Twain (Author and lecturer)

Although the spin-off benefits most commonly associated with military spending are material, the contribution of military spending to human capital also holds a deep importance. In addition to the direct employment effects of military spending, military spending also affects the labour market in terms of skills development and through the production of educational spinoffs. To determine the degree and nature of these training spinoffs requires first a deconstruction of military training into its component parts. While civilian training is designed to match a specific civilian profession, this is not the case with military training, nor do all types of military training necessarily have a civilian application. Furthermore, the boundary between military professions and civilian professions is neither altogether clear nor static. Even though the training of soldiers is clearly a military activity, there must be careful consideration for how to treat civilian skills training which was conducted in order to service contracts for the military. Of crucial importance is the uniqueness of how the military institution relates to the state and what impact this has on the spinoffs of military training. Martial skills and combat training are exclusive to the military, making an understanding of their wider effects especially important to an

\footnotetext{
${ }^{185}$ Mark Twain, “As Regards Patriotism,” A Pen Warmed Up in Hell: Mark Twain in Protest. ed. Frederick Anderson, (New York: Harper and Row Publishers, 1979).
} 
understanding of human capital development. Finally, the military is special for understanding itself to be a sort of Praetorian Guard for national well-being and thus, the military has a strong influence in defining what the national well-being is. The transmission of these types of institutional and social values through military training can have a wider impact on society, depending on how they are undertaken. Military training has a large capacity for spill-over effects into the wider state and society as a whole which must be understood in order to comprehensively value the spinoff effects of the military.

The skills and training most commonly attributed to the military are sometimes mistakenly dismissed for having little conceivable benefit beyond the extended family of martial professions which require an aptitude for coercion. ${ }^{186}$ While the coercive skills uniquely required by the profession of arms do deserve special attention, to assume that military training is limited to martial skill is a mistake. Consider that even while there are those in the military whose training is strictly limited to combat, those 'combat professionals' still require supplies, transportation, orders and weapons, all of which depend on a more diverse range of skills training than coercion alone. Thus, there exists a significant portion of military activities which are not primarily combative in nature. These non-combat trades and skills are greatly more compatible and comparable with the occupations of the civilian sector and must be treated differently in any examination of skills spinoffs. To encompass this distinction

\footnotetext{
${ }^{186}$ Non-military martial professions including those such as policing, intelligence or private security are good examples of fields where military training has a practical application, although the match is imperfect. Even in the most comparable aspects, the use of small arms for example, soldiers migrating into civilian professions like policing require retraining. In this case it is because civilian small arms are not designed the same way as military arms and do not have the same built-in redundancies. Whereas military ammunition is a clear fit into the firearm or not, there are literally hundreds of types of civilian ammunition and many can fit into the wrong firearm, causing misfires or even explosions when used improperly
} 
between combat and non-combat skills, the activities of the military are generally divided into two categories: either the category of 'tooth', representing those activities that are more tactical and combat-specific, or the category of 'tail', representing those activities that are more logistical and strategic.

Before identifying the share of military activities dedicated to each category, it is worth noting that the amount of energy dedicated to the strictly combat share of training has been historically variable. With the nature of war in constant evolution, the training requirements necessary to attain a basic proficiency in combat have changed with the times. The knights of the $16^{\text {th }}$ century, for example, required a near lifetime of martial training to be proficient in combat, compared to the rifling conscripts of the $19^{\text {th }}$ century who could achieve basic martial proficiency rather quickly, compared to the jet fighter pilots of the $21^{\text {st }}$ century who, again, require a near lifetime of training. ${ }^{187}$ In this sense, the human capital investments required for martial proficiency in a given epoch will change depending on the nature of war, as consequently will the degree of spinoffs attributed to equivalent amounts of military training across time periods. There is therefore no universal law governing the spinoffs of military skills training. The important question then becomes: what is the trend most representative of the present-day? Certainly in the years immediately following the Second World War, the most remarkable trend among developed countries was towards reduction of the number of conventional forces in favour of nuclear weapons and specialized high technology. Throughout the Cold War and into the early 1990s, the cost of arms and equipment continuously gained an increasing share of the military budget. Through these years, the cost of arms increased at a rate of approximately $10 \%$ per annum and greatly outpaced

${ }^{187}$ Gwynne Dyer, War, 205-285. 
the increases in the pay of soldiers. ${ }^{188}$ This relative decline in the importance of combat soldiers was part of the increasing sophistication of military equipment and of the increasing proportion of training necessary to employ the complex weapon systems of the day. ${ }^{189}$ From a high-level analysis, these observations would seem to indicate a tendency throughout the $20^{\text {th }}$ century for proportionately less energy being dedicated towards combat-oriented training.

In order to get a more scientific estimation of what proportion of military training is dedicated to combat versus non-combat competencies, analysts use the socalled 'tooth-to-tail ratio' (T3R). Calculating the T3R provides a rough approximation of what amount of training is dedicated to martial skill and what is dedicated to the types of logistical skills that are likely to have closer civilian equivalencies and human capital transferability. Using the T3R to this end, however, has one glaring deficiency; all military personnel, regardless of whether their primary trade or occupation is combat-oriented or not, receive core (basic) training which heavily emphasizes martial skill. ${ }^{190}$ Keeping in mind that the T3R then under-represents the primarily martial character of core training, the T3R can nonetheless provide a representative look into the core function of training that soldiers receive, thereby establishing a foundation for sketching the spinoffs of military training.

The T3R is a subject of much discussion in military circles given its importance to combat readiness and due to the difficulties that come with its precise estimation. It is difficult to determine with certainty which tasks are 'tail' or 'tooth' since both

\footnotetext{
${ }^{188}$ Keith Hartley, “The Case for Defence," Defence and Peace Economics. 2010, 409-426. Similar calculations to these resulted in the cheeky 'Augustine's Law' through which Norman Augustine calculated that by the mid-2030s all of the United States military budget would be spent operating one plane that would have to be shared by the Army, Navy and Air Force, on rotation through different days of the week.

${ }^{189}$ For more see: Maurice Greenburg, "Trends in U.S. Military Spending," Council on Foreign Relations. June $28^{\text {th }}, 2011.7$.

${ }^{190}$ The issue of core (basic) training is touched on briefly only here because is addressed at greater length later in the chapter.
} 
functions are so fundamentally intertwined at some level. This has resulted in divergent estimations of the T3R for given points in time. One of the more trusted estimations was conducted by John McGrath, who sought to capture the long-term historical trends in the T3R. By his estimations of the American military's T3R, in 1900 , 'tail' represented an average of approximately $20 \%$ of the total U.S. forces ${ }^{191}$, but by the First World War, 'tail' had risen to approximately 30\%. ${ }^{192}$ By the Second World War, 'tail' activities had grown to represent approximately $60 \%{ }^{193}$ of military effort, rising again to $65 \%$ by the middle of the Vietnam War in $1968 .{ }^{194}$ By 1974 , tail represented fully $73 \%$ of military activities ${ }^{195}$ decreasing slightly by the 1991 First Gulf War to $70 \%{ }^{196}$ before rebounding during the Second Gulf war to $75 \%$ in $2005 .{ }^{197}$ In other words, McGrath argues that the 'tail' functions of the military have steadily risen since the early $20^{\text {th }}$ century, which would imply that the share of transferable training has similarly increased. Of course, it should also be noted that this analysis views the military in aggregate even though some services, like the Army and Navy, place relatively more importance on combat specific skills than the Air Force. ${ }^{198}$ With that caveat identified, the fact remains that there is an clear and observable trend towards more 'tail' and less 'tooth' with military skills training gaining an increasingly important spinoff value.

There is still, however, some disagreement about T3R estimates, ${ }^{199}$ especially

\footnotetext{
191 John McGrath, The Other End of the Spear: The Tooth-to-Tail (T3R) in Modern Military Operations, (Fort Leavensworth, Kansas: Combat Studies Institute Press, 2007) 11.

${ }^{192}$ Ibid 12

193 Ibid 19

${ }^{194}$ Ibid 31

${ }^{195}$ Ibid 34

${ }^{196}$ Ibid 42

197 Ibid 53

${ }^{198}$ Mangum, Steven and Ball, David. "Military Skill Training: Some Evidence of Transferability," Armed Forces and Society. Spring 1987: 431

${ }^{199}$ It is important to note that part of the source for disagreement includes the differences between peace-time and war-time estimates. For consistency, McGrath only selects war-time examples however it is important to note that war-time examples generally have a larger 'tail' than those of peace-time. It would seem logical that the more optimistic assessments of the T3R would be less representative since they do not withstand the rigors of war, which seems to have been McGrath's reasoning. Regardless, McGrath's study allows a firm basis for concluding that in the past century, 'tail' has greatly increased its
} 
the more recent estimations of the T3R that follow the First Gulf War. Some suggest that starting in the mid-2000s, the trend for less 'tooth' was reversed, and 'tail' began a steady decrease in its share of the T3R. The dispute in estimation stems fundamentally from a disagreement of how the effects of privatization in the military should be treated. McGrath concludes that exclusion of civilian contractors from some estimates has artificially depressed the logistical burden that is measured in the conflicting studies. In other words, the simultaneous privatization and civilianization of military logistical functions does not actually reduce the logistical 'tail' of military operations, except cosmetically. ${ }^{200}$ Although consensus continues to be elusive, it suffices to note that others agree with McGrath's conclusions in broad strokes. Bland, for instance, suggests that, in the Canadian Forces, 'fewer than a third (of personnel) are trained combat soldiers. ${ }^{201}$ McKinsey \& Company similarly estimated in 2008 that across the militaries of developed countries 'tooth' on average represented about $26 \%$ of the $\mathrm{T} 3 \mathrm{R} .{ }^{202}$ For the purposes of an analysis of training and human resources in the military, assuming a low and perhaps even decreasing share of 'tooth' seems to be the most logical course of action. Regardless of the direction taken by the T3R, the fact remains that today most service-people now dedicate the bulk of their military education on subjects that are peripheral to direct combat.

\footnotetext{
share of the T3R and 'tooth' now represents roughly $1 / 3$ of the T3R.

${ }^{200}$ This subject is addressed in greater detail in pages 50-54 of The Other End of the Spear. Indeed, when examining the T3R in its long historical context as McGrath has done, there seems to be strong evidence in favour of his conclusion. It is worth noting that the introduction of legislation in the 1970s that mandated a certain 'tooth' share of T3R, a share that McGrath would suggest is not possible, may be partially responsible for the confusion. Certainly it gives pause to look at the graphical representation of long-term T3R, and where the wide-spread introduction of military contractors are situated in relation to the legislated maximum share of 'tail'.

${ }^{201}$ Douglas Bland, Time Bomb, (Toronto: Dundurn, 2014) 117.

202 "McKinsey on Government: Special Issue on Defence," McKinsey and Company, Spring 2010, 7.
} 


\subsection{Tail}

The types of skills required by the military 'tail' include a wide variety of professions that range from electricians, to accountants, to dentists. To use the Canadian Forces again as an example, the 'Infantry Soldier' that is most often associated with service-people actually only represents one of 93 possible trades in the Canadian military. ${ }^{203}$ Militaries require a wide variety of skills and professionals in order to conduct themselves effectively, which is especially important when considering that the nature of conflict often requires the military to be able to operate with relative independence from the rest of the state and society if need be. This imperative necessitates military mechanics, electricians, cooks and cleaners, as well as military administrators, telecommunications professionals, policy advisers and aerodynamic engineers. Let us consider for a moment the familiarity of these professional titles to those of the civilian world. There is, in principle, '...little reason to doubt the viability of the military as a training provider offering linkage to the civilian world. ${ }^{204}$ Even with the understandable difficulty in accurately estimating the transferability of military trades training, 'it has been suggested that there are civilian counterparts to approximately $80 \%$ of military occupational specialties. ${ }^{.205}$ Certainly, such high estimations of trade transferability between civilian and military occupations would seem to be a clear indication of potential for training spinoffs, especially for the non-combat military occupations that compose the 'tail'. ${ }^{206}$

\footnotetext{
${ }^{203}$ Canadian Forces, "Canadian Forces Jobs," Canadian Forces. nd. December $12^{\text {th }} 2014,<$ http://www.forces.ca/en/jobexplorer/browsejobs-70>.

${ }^{204}$ Mangum, Steven and Ball, David. "Military Skill Training: Some Evidence of Transferability," Armed Forces and Society. Spring 1987:

${ }^{205}$ Steven Mangum and David Ball, "Military Skill Training: Some Evidence of Transferability," 426.

${ }^{206}$ It is also worth noting a strong relationship between military officers and the world of business with male military officers being almost three times more likely than the average to become CEOs. Although this connection has yet to be fully explored, suffice it to include here that there may be other professional spinoffs of military service still to be defined.
} 
To examine the positive implications of training transferability, it should be noted that degree of transferability and spinoffs of training in the 'tail' is dependent on a variety of factors. Not the least of these factors is the extent that training required for military effectiveness matches with the skill demands of the civilian labour market. One study from the 1980s sought to gauge the transferability of skills by occupation taken after employment in the military and concluded that:

'For males, the incidence of skill transfer by occupational area of training was the greatest in farm/transportation (71\%), management (67\%), crafts (61\%), and services (60\%). For females, skill transfer was most prevalent among those receiving training in clerical occupations (71\%) and technical occupations (47\%). ${ }^{207}$

Certainly, some of these observations of skill transfer will likely hold true in the present-day; the functional requirements of truck driving in the civilian and military fields are not likely to have changed a great deal since the 1980s. Yet with the relative decline of manufacturing employment in the advanced economies since that time, it is quite likely that the training spin-off value of 'crafts' has declined. The change in demand for certain skills occurs in the civilian sector regardless of the changes occurring in the skills requirements of military effectiveness. For instance, combat engineers and mechanics are no less important to military effectiveness due to the relative decline of their equivalences in the civilian sector. This is illustrative of the fact that the spinoff value of military training must be highly context-driven and that

\footnotetext{
à Tim Kane, "Why Our Best Officers are Leaving," The Atlantic. January 4, 2011.

$<$ http://www.theatlantic.com/magazine/archive/2011/01/why-our-best-officers-are-leaving/308346/>. March $14^{\text {th }}, 2015$

${ }^{207}$ Steven Mangum and David Ball, "Military Skill Training: Some Evidence of Transferability," 432
} 
military training is not nearly as responsive to market pressures as the sectors which may employ military veterans. It is important to keep in mind that,

'Unlike many training institutions, the military may not view its primary function to be that of providing transferable skills... Society has not commissioned the military to be, first and foremost, a provider of transferable training, just as it has not required it of other employers providing training as a by-product of producing a good or service. $^{208}$

Indeed, the military has a function to perform separate from the training it provides and the spinoff value of individual military trades training may in some cases just be the luck of the draw. Keeping in consideration that the military's primary function is not to provide skills training, military training can nonetheless responsive to market developments as changes in technology provide the military with opportunities to improve its strategic advantage over adversaries. This would seem to be the case with the contemporary adoption of new technologies and increasing sophistication of skills that come with it. New and technologically sophisticated equipment will similarly necessitate new types of military training that will be likely to have more overlap in the civilian labour market due to its timeliness. ${ }^{209}$

The increasing interchangeability of skills between the military and civilian sectors can be evidenced in part by the degree to which civilians are employed to perform military functions. As an example, 'U.S. Department of Defense employed 155,826 private contractors in Iraq (compared with) 152,275 troops. This degree of

\footnotetext{
${ }^{208}$ Steven Mangum and David Ball, "Military Skill Training: Some Evidence of Transferability," 426 ${ }^{209}$ Ibid pg 426
} 
privatization is unprecedented in modern warfare. ${ }^{.210}$ This trend towards increasing interchangeability has raised questions about how many of these traditionally military trades and functions could be just as well performed by the civilian sector. The boldness of the argument may be indicative of how much interchangeability of skills has increased as the services of private contractors today are estimated to represent upwards of $25 \%$ of all activities core to the U.S. military compared to a historic norm of closer to none. ${ }^{211}$ These new civilian defence industries, along with the traditional ones, '... attract highly trained workers and engineers (from the civilian sector and) thus have a draining effect on human resources. ${ }^{212}$ Although the increasing interchangeability of skills can serve to spin-off military training into the civilian sector, interchangeability is a two-way street. This civilianization of military functions may ultimately serve to put military training and recruitment into more direct competition with the civilian labour market. ${ }^{213}$

As the interchangeability between civilian and military skills increases with proximity to new technologies, it would be valuable to briefly examine the relationship of the military to the Information Communications Technology (ICT) sector as a bellwether of the increasing interchangeability of skills overall. Remaining of course cognisant of the fact that 'some portion of military training is institution-specific and

\footnotetext{
${ }^{210}$ Molly Dunigan, “A Lesson from Iraq War: How to Outsource War to Private Contractors," Rand Corporation Blog. March 19 ${ }^{\text {th }}, 2013$. January $18^{\text {th }}, 2015$. $<$ http://www.rand.org/blog/2013/03/a-lessonfrom-iraq-war-how-to-outsource-war-to-private.html >.

${ }^{211}$ John McGrath, The Other End of the Spear: The Tooth-to-Tail (T3R) in Modern Military Operations, $50-54$.

${ }^{212}$ Uk Heo, "The Relationship between Defence Spending and Economic Growth in the United States," 761.

${ }^{213}$ Although it is unfortunate to have to oversimplify an important and timely issue such as private military contractors, engaging in this topic any more than absolutely necessary comes with the risk of detracting from the core argument of this work. Among the gamut of issues raised by PMCs for the military, there are several that are worth noting in the context of skills development. Firstly, how does the introduction of contracting effect the specialization of trades? What type of institutional values will be held, developed and propagated by PMCs vs. traditional militaries? How does contracting change the type of social groups that are able to access military training?
} 
thus, by definition, unlikely to be transferable ${ }^{214}$ in a situation like that of ICT, the skills training provided by the military could certainly be a valuable spinoff into the civilian economy. Israel, for example, has sought to overlap a strategic emphasis on military high technology with its budding civilian ICT cluster. This intentional overlap in specialization has equipped veterans with highly sought-after skills training, resulting in greater post-service employment and effectively subsidizing the ICT sector's growth in Israel by providing it with an affordable labour market. ${ }^{215}$ This provides a strong positive example for the interchangeability of skills increasing the value of military training to the civilian sector.

On the other hand, the mutual adoption of new technologies by the military and civilian sectors could easily put the resource demands of the two sectors in competition with one another. To examine a recent example from the United States, in 2013 the demand for cyber security professionals was 12 times that of the overall job market while, at the same time, cyber-warfare was similarly determined to be a high priority area for the military. ${ }^{216}$ Although the effects of this have yet to be fully seen, it would be logical that the military's demand for these timely skills would contribute to crowding-out the market for human resources in a similar manner as described for military R\&D spending in earlier chapters. It is quite possible then that this military demand burden in the civilian sector would produce a drag on civilian human resources by placing additional cost-pressures on civilian industries and diverting

\footnotetext{
${ }^{214}$ Steven Mangum and David Ball, "Military Skill Training: Some Evidence of Transferability," 437

${ }^{215}$ Priscilla Offenhauer, "Israel's Technology Sector," Federal Research Division of the Library of Congress. (Washington: November 2008) 6-8.

${ }^{216}$ Steve Rosenbush, "The Demand for Cyber Security Jobs is Soaring," The Wall Street Journal, March $4^{\text {th }}$, 2013. January $17^{\text {th }}, 2015$. $<$ http://blogs.wsj.com/cio/2013/03/04/demand-for-cyber-security-jobs-issoaring/>.

Sean Lyngaas, "For Army Cyber, it's on-the-job training," FCW. November $21^{\text {st }}, 2014$. January $17^{\text {th }}$, 2015. < http://fcw.com/articles/2014/11/21/army-cyber.aspx $>$.
} 
human resources away from more economically efficient uses. In other words, the interchangeability of tasks and skills between the military and civilian sectors is a double-edged sword with equal potential to help and harm economic performance.

The major difference between these two examples is, of course, that the Israeli military is composed of conscripts while the U.S. military is based on voluntary recruitment. The distortion effect of the priorities of human capital is one of the tradeoffs which comes with military recruitment through All-Volunteer Forces (AVFs) instead of conscription, as the use of market incentives in the recruitment and retention of the military invites competition between military and civilian priorities in the labour market. On one hand, AVFs hold an economic advantage over conscription based systems since recruits may choose among military sub-professions, '...suggest(ing) greater chances of skill transfer between the military and civilian sectors today than in (conscription systems) and conceivably greater potential returns on training acquired in the military ${ }^{\prime 217}$ as recruits are better matched to job functions. However, this invitation of the market into the realm of military recruitment comes part and parcel with increased costs associated with military and civilian payrolls. This is because military pay must be raised enough to become relatively competitive with remuneration offered in the civilian sector, resulting in overburdening costs for highly demanded skill-sets.

This is compared to conscription-based recruitment systems which do not need to offer competitive wages and can have their draft eligibility tailored to underutilized groups, namely un(der)-employed and un(der)-skilled youth. ${ }^{218}$ Returning to the

\footnotetext{
${ }^{217}$ Steven Mangum and David Ball, "Military Skill Training: Some Evidence of Transferability," 427

${ }^{218}$ While it may seem out of vogue to reintroduce a discussion about the values of conscription in the present-day environment of relative peace, it is worth recalling that for most of the history of the state,
} 
example of Israel, Israelis often celebrate their conscription-based military as being the bedrock of the Israeli ICT cluster and attribute it with driving the culture of start-ups, most notably in the best-seller 'Start-Up Nation'. ${ }^{219}$ Of course, conscription is not strictly or by definition economically advantageous. Although difficult to quantify, '(the) withdrawal of a large part of the young - and certainly very productive population from the civilian sphere, and the economy in particular, occasions economic harm at the national level. ${ }^{, 20}$

In essence, the more indiscriminate nature of conscription ensures that many young men would spend a large part of their most productive years doing something potentially less productive than they might have done otherwise; imagine Elvis Presley spending time as a GI rather than an international music and cinematic sensation. The outcome of conscription costs will certainly vary somewhat from country to country 221 but a recent Swiss study concluded that labour force economic opportunity costs of their conscription policy can be estimated in the range of 'one-and-a-half to two times greater than the direct expenditures allocated for the military. ${ }^{222}$ Although economic spinoff considerations are seldom the factors which determine the choice between conscription or AVF, this problem of competing human resource needs raises

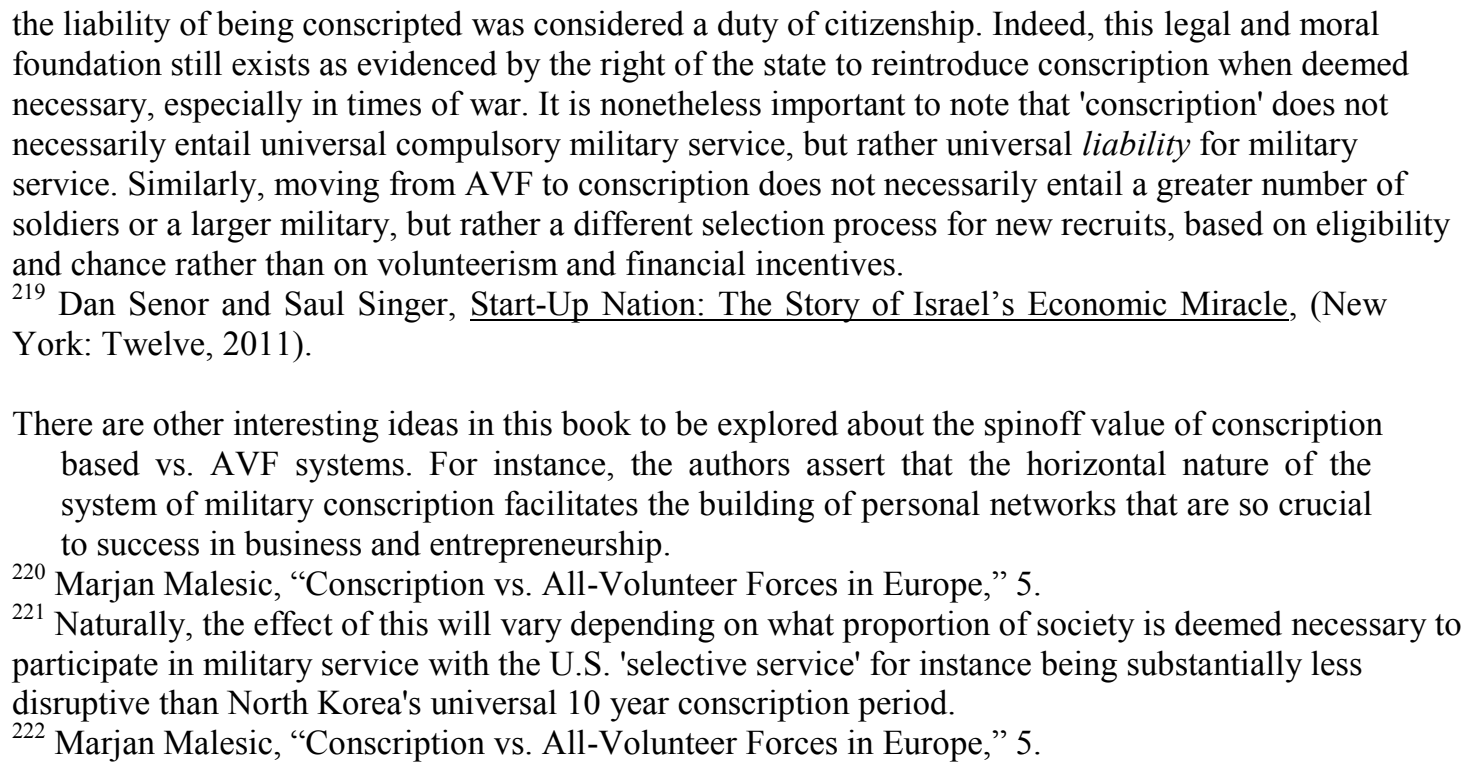
foundation still exists as evidenced by the right of the state to reintroduce conscription when deemed necessary, especially in times of war. It is nonetheless important to note that 'conscription' does not necessarily entail universal compulsory military service, but rather universal liability for military service. Similarly, moving from AVF to conscription does not necessarily entail a greater number of soldiers or a larger military, but rather a different selection process for new recruits, based on eligibility and chance rather than on volunteerism and financial incentives.

219 Dan Senor and Saul Singer, Start-Up Nation: The Story of Israel's Economic Miracle, (New York: Twelve, 2011).

There are other interesting ideas in this book to be explored about the spinoff value of conscription based vs. AVF systems. For instance, the authors assert that the horizontal nature of the system of military conscription facilitates the building of personal networks that are so crucial to success in business and entrepreneurship.

${ }^{220}$ Marjan Malesic, "Conscription vs. All-Volunteer Forces in Europe," 5.

${ }^{221}$ Naturally, the effect of this will vary depending on what proportion of society is deemed necessary to participate in military service with the U.S. 'selective service' for instance being substantially less disruptive than North Korea's universal 10 year conscription period.

${ }^{222}$ Marjan Malesic, "Conscription vs. All-Volunteer Forces in Europe," 5. 
important questions about which types of individuals are likely to receive military training and the degree to which this will compete with the demands of the civilian sector.

As previously noted, the military is typically composed of young (mostly) men who have a high likelihood of otherwise being unemployed. With this fact in mind, it should be of little surprise to note that, '...those with a high school diploma appear to be less likely than those without a degree or those with advanced education to join the reserve (military)...'223 and that, 'almost all those joining the military services as enlisted personnel have little or no relevant prior skill training or job experience. ${ }^{224}$ This would seem to support the common wisdom that the military typically does not compete for human resources in the labour market, rather that the military tends to engage and train unskilled labour that was likely not being put into its optimal use in the first place. If true, this would be strong evidence supporting the suggestion that military training has a valuable spinoff since it tends to convert unskilled labour into skilled and (sometimes) highly demanded labour. While this observation about the youthful and unskilled nature of recruits may have been true in the past, ${ }^{225}$ there are signs that the composition of military recruits is changing. ${ }^{226}$

While the role of 'tail' in warfare increases, there is a diminishing relative importance of combat troops and a similarly diminishing emphasis on attracting new recruits that are young and in their physical prime. Since physical prowess is less of a pre-requisite in the highly skilled and technology-centric armed forces of today,

\footnotetext{
${ }^{223}$ Susan Marquis and Sheila Nataraj Kirby, "Reserve Accessions Among Individuals with Prior Military Service: Supply and Skill Match,” Rand Corporation. October 1989. 33.

${ }^{224}$ Henry Solomon, "Economic Issues in Cost-Effectiveness Analysis of Military Skill Training," Institute for Defence Analyses. March 1986. 3.

${ }^{225}$ Note that the above references to military recruitment from unskilled labour pools are from the $1980 \mathrm{~s}$ and are thus somewhat dated.

${ }^{226}$ Rosa Brooks, "No Army for Young Men," Foreign Policy. September 27th, 2012. January 18th, 2015. < http://foreignpolicy.com/2012/09/27/no-army-for-young-men/>.
} 
some have begun to wonder whether the military should continue to pursue recruitment of the young men who have traditionally been the staple of the armed forces.

'It's time to question the near universal assumption that the ideal military recruit is young and male. The nature of warfare has changed dramatically in the last century and the capabilities needed for the military are less and less likely to be the exclusive possession of young males. In fact, the opposite may be true...young males may (now) be one of the least well-suited demographic groups... Being young, male and strong offers no particular advantage to an Air Force drone pilot or an Army financial services technician... As the world grows more complex - as the skills needed to ward off security threats become more subtle and varied - wouldn't we do better to radically rethink military recruitment strategies? Better still, why not reconsider the whole military progression, creating more of a revolving door between the military and civilian world ${ }^{227}$

Indeed, the steadily increasing 'tail' of the military represents a fundamental change to the nature of military training spinoffs as it has tended to improve the transferability of skills between the military and civilian sectors. While this conceivably has the potential to result in the military providing valuable skills and education to the young and otherwise unskilled, what is actually occurring is that being young and unskilled is no longer as important for military recruits. This trend is

${ }^{227}$ Rosa Brooks, "No Army for Young Men," 
blunting the military's traditional ability to provide skills training to the young and uneducated. Simultaneously, the marketization of military recruitment and skills has brought military recruitment into closer competition with the more economically productive civilian sector.

\subsection{Tooth}

Martial training is unique to the military and deserves special consideration. Indeed for much of human history, participation in military training was a special privilege and the, '...admiration of the warrior spirit and prowess in war was pervasive; war was thought a proper source of education. ${ }^{122}$ The military is first and foremost the 'profession of arms' and all modern militaries have basic martial and educational regimes that are requirements for every military trade or sub-profession. In spite of the emphasis on battle in literature and cinema, the reality is that most of a soldier's time in the military is dedicated not to combat, but to training. Even in times of war, 'only a small part of time is occupied by action... The end for which a soldier is recruited, clothed, armed and trained, the whole object of his sleeping, eating, drinking, and marching is simply that he should fight at the right place at the right time,,$^{1229}$ and this represents a sliver of time in a soldier's career. As an example, the Defence Business Board has estimated that even during the simultaneous wars in Iraq and Afghanistan, approximately $40 \%$ of active duty U.S. soldiers were never even deployed overseas. ${ }^{230}$

To unpack the significance of this, a combat soldier could very well spend most of a life-long career in the military training and repeating the necessary

\footnotetext{
${ }^{228}$ Ron Smith, Military Economics: The Interaction of Power and Money, 9.

${ }^{229}$ Carl Von Clausewitz, On War, 23, 38.

230 Arnold Punaro et al. "Reducing Overhead and Improving Business Operations: Initial Observations," Defence Business Board, July 22, 2010, 23.
} 
motions thousands of times to accurately hit a target ${ }^{231}$, and ultimately never have the occasion to put this skill to use. Considering that not all soldiers serve during wartime, not all units in wartime see combat and not all members of each combat unit have the occasion to fight, this amounts to a remarkable amount of time, money and human energy being expended to perfect seldom-used combat skills with marginal civilian applicability. Doubtless, it would be tilting at windmills to suggest that, since the economic spinoffs associated with training in martial skill are low, martial training in the military should therefore be minimized. ${ }^{232}$ There are nonetheless some economic benefits to the combat skills which comprise the 'tooth' activities of the military, most notably of course the ability to use these skills in civilian fields such as policing.

There are also indirect spinoffs to martial training as well and the, '...completion of a full enlistment may indicate greater skill endowment and signal greater perseverance and dependability to civilian employers. ${ }^{233}$ Compared with other forms of training however, military provided training, '... typically occurs in a different geographic area than where the individual hopes to reside and consequently limits the possibility of linkage building. ${ }^{.234}$ All told, the human capital spinoffs from combat training are marginal and perhaps even disadvantageous when compared with an equivalent training regime undertaken in the civilian sector. There are also special characteristics of combat training in modern warfare which could very well represent hidden costs. Indeed, modern combat and combat training are rather unique enterprises which have much greater effects on those concerned than any other type of training

\footnotetext{
${ }^{231}$ As is commonly said in military circles, 'In combat you do not rise to the occasion but sink to your lowest level of training.' As such, seemingly excessive repetition is a common and necessary feature of military training.

${ }^{232}$ Indeed, an evisceration of the military's core competencies would be very much against the spirit of this work, not to mention counter-productive to improving the output of military spending which itself must most certainly include military effectiveness.

${ }^{233}$ Rosa Brooks, "No Army for Young Men," 429

${ }^{234}$ Ibid pg 438
} 
endeavor.

Modern combat training first began to gain its own character along with the invention of mass produced weapons and invention of mass conscription during the $18^{\text {th }}$ century. ${ }^{235}$ As these changes to war and training became fully realized, the nature of combat become less and less comparable to the traditional enterprise until it more closely resembled an entirely new venture as presented by the American Civil War in the mid- $19^{\text {th }}$ century. ${ }^{236}$ Shedding light on a remarkable juxtaposition of old military values clashing with the new during this epoch, Gwynne Dyer recounts the story of a cavalry officer in the American civil war. Having successful charged the enemy lines, the cavalry officer reared his horse while yelling a battle cry,

'...but within seconds, both he and his horse were shot down by less romantic men. The cry that had gone up was an echo from the eighteenth century when it had thought to be unsporting to aim at individual enemies, especially officers; everybody took his chance equally in the hail of unaimed volley fire. ${ }^{237}$

Although it may be surprising to hear in the present-day, the necessity to train soldiers to shoot precisely and reliably at enemy soldiers is a relatively new phenomenon in warfare and represents the early beginnings of what would become huge changes to the training regimen. While soldiers have been trained to shoot at, and hit, targets since gunpowder become a part of the military toolkit, this did not immediately transform into the ability to hit other soldiers. Even though new technologies would increase military fighting potential, 'the ultimate utility of a weapon... depends on more than its inherent technological properties or its cost

\footnotetext{
${ }^{235}$ Gwynne Dyer, War, 205-285.

${ }^{236}$ Although the social effect of this military revolution entered into public discourse on society immediately following the First World War, these new elements of warfare were first realized in the American Civil war.

${ }^{237}$ Gwynne Dyer, War, 245-246
} 
effectiveness. It depends on how well it is used. ${ }^{238}$ The technological revolution that occurred in weaponry would ultimately require a commensurate revolution in training. These initial training deficits become clear in a historical analysis of the American Civil War and Napoleonic Wars where,

'With (the standard weapon's) hit rate of well over $50 \%$ at the average combat ranges of this era, the killing rate should have been hundreds per minute, instead of (the) one or two (per minute which actually occurred).The weak link between the killing potential and the killing capability of these units was the soldier. The simple fact is that when faced with a living, breathing opponent instead of a target, a significant majority of the soldiers would (posture) and fire over the enemy's heads. ${ }^{239}$

Similar discrepancies between the killing potential and actual killing of enemy soldiers by military units was also found in both subsequent World Wars, where as few as one in ten soldiers, and no more than one in four, would consistently take aim and fire at enemy combatants with the intention to hit them. ${ }^{240}$ In a fairly typical account from a veteran of the Second World War it was noted that, 'Squad leaders and platoon sergeants had to move up and down the firing line kicking men to get them to fire. We felt like we were doing good to get two or three men out of a squad to fire.'241 Although perhaps welcome news for idealists, the existence of a profound

\footnotetext{
${ }^{238}$ Risa Brooks, "The Impact of Culture, Society, Institutions, and International Forces on Military Effectiveness." Creating Military Power. Eds Risa Brooks and Elizabeth Stanely, (Stanford: Stanford University Press, 2007) 13.

${ }^{239}$ Dave Grossman, On Killing: The Psychological Impacts of Learning to Kill in War and Society, (New York: Little Brown, 2009) 11.

${ }^{240}$ S.L.A Marshall, Men Against Fire: The Problem of Battle Command., (New York: William Morrow, 1947).

${ }^{241}$ Dave Grossman, On Killing: The Psychological Impacts of Learning to Kill in War and Society, xvii
} 
psychological aversion to killing presented the military with a difficult training challenge since, ultimately, the ability of soldiers to kill is an important part of combat effectiveness. This was done in part by increasing the intensity of obedience training and, 'the whole edifice of the military institution (now) rests on its ability to obtain obedience from its members even unto death- and the killing of others. ${ }^{242}$ At the same time, post-War military training would also emphasize new training techniques that would help to reduce the psychological barriers to killing as a means of improving overall military effectiveness.

The various techniques, ${ }^{243}$ first adopted by the United States and then more widely in most professional militaries world-wide, were ultimately successful in improving 'kill ratios' in subsequent conflicts and, hence, overall military effectiveness. While a success by this measure, there has been a strong, if yet fully uncovered, relationship between the new skills required for combat and the propensity for psychological injury. The often sanitized fact of the matter is that the military is the only profession which at its core requires competency in killing, and there are hidden psychological consequences of training to kill, and killing itself. While PostTraumatic Stress Disorder (PTSD) seems to have always existed in some measure under different names ${ }^{244}$, there seem to have been markedly higher rates of PTSD

\footnotetext{
242 Gwynne Dyer, War, 31.

${ }^{243}$ Many of these techniques are so common now as to seem unremarkable. They include, for example, the use of silhouettes resembling human figures for target practice instead of round bulls-eye targets, and targets which 'pop up' and move around so as to resemble human movement. The central guiding principle of the revolution in training is conditioning, which seeks to make simulation as close to reality as possible so that combat seems familiar and instinctive, thereby enabling soldiers under duress to act consistently and without hesitation.

${ }^{244}$ Although PTSD is the preferred term at the moment, the phenomena describing the difficulty of soldiers to reintegrate into society after a conflict has also been known as, shell shock, soldier's heart, battle fatigue, combat stress reaction and many others. (Judith Herman, Trauma and Recovery: The Aftermath of Violence from Domestic Abuse to Political Terror, (New York: Basic Books, 1997). )
} 
observed in the conflicts which have followed the Second World War. ${ }^{245}$

Granted, there is an important distinction to be made between combat and training for combat, but in an examination of the externalities of 'tooth', this remain an important consideration. American studies comparing two groups of veterans have indicated that soldiers returning from the Vietnam War have significantly higher rates of PTSD than their Second World War counterparts and commensurately higher instances of associated issues such as alcoholism, drug abuse, marital problems, and joblessness. ${ }^{246}$ Although causality is difficult to prove, it seems likely that the new necessities accompanying war's evolution are associated with greater psychological pressures being placed on soldiers. As lucidly expressed by one psychiatrist, 'Just as the physical health of the caisson worker would be endangered if he left his diver's chamber suddenly (where he is under enormous atmospheric pressure), so the man who has suddenly been liberated from mental pressure can suffer damage to his moral and spiritual health. ${ }^{247}$

In this sense, there is a hidden cost to combat that detracts from the ability of soldiers to reintegrate effectively in society once their participation in hostilities has

\footnotetext{
${ }^{245}$ There is degree of healthy skepticism that needs to be applied to this assertion as, like with most types of statistical analysis, the information pre-dating the Second World War is typically less reliable than that which has preceded it. With that said, rates of PTSD have certainly, and consistently been measured in greater quantity following the Second World War. (Judith Herman, Trauma and Recovery: The Aftermath of Violence from Domestic Abuse to Political Terror,)

${ }^{246}$ Dave Grossman, On Killing: The Psychological Impacts of Learning to Kill in War and Society, 263293.

${ }^{247}$ Victor Frankl, Man's Search for Meaning, (Boston: Beacon Press. 1959) 90
}

While Frankl is writing about concentration camps more specifically, it was discovered following the Second World War that the trauma of soldiers and concentration camp survivors was similar enough in form and treatment to be placed into the same category. This is the reason for the change from using older terms like 'shell shock' were incorporated into the more broad term, PTSD, which applies to more than psychological damage from military participation. (Judith Herman, Trauma and Recovery: The Aftermath of Violence from Domestic Abuse to Political Terror) 
concluded. Although inherently tricky to calculate, a 2008 study by the RAND Corporation estimated the cost of PTSD in U.S. soldiers stemming directly from the wars in Iraq and Afghanistan at between $\$ 4$ billion and $\$ 6$ billion spread over two years. ${ }^{248}$ However, these estimates are far from conclusive. For example, another study indicated that there may be diagnosable traumatic effects of living with a family member with PTSD, known as Secondary Traumatic Stress Disorder (STSD) that has not yet been accounted for in other analyses. ${ }^{249}$ The treatment of externalities such as STSD in cost estimations makes it clear that while it may not be possible to precisely determine the costs of combat, they are substantial. It is perhaps best described by Paul Kennedy, who wrote that, 'there is no known way of measuring the personal anguish and the psychological shocks involved in such a human catastrophe (as modern war)... ${ }^{250}$

\subsection{Institutional Education}

These features of combat would seem to represent a negative spin-off of core military service and training, but military service more broadly has unattributed positive spin-offs as well. For one, the values adopted and emphasized during military training can be adjusted to serve purposes of constructive national acculturation, much in the same way as universal compulsory education did during the late early-

\footnotetext{
${ }^{248}$ Ann Scott Tyson, “Combat Stress May Cost up to \$6 Billion,” The Washington Post. April 18, 2008. January $18^{\text {th }}, 2015$. $<$ http://www.washingtonpost.com/wpdyn/content/article/2008/04/17/AR2008041701749.html>.

${ }^{245}{ }^{249}$ R Lev-Wiesel and M Amir, "Secondary Traumatic Stress, Psychological Distress, Sharing of Traumatic Reminiscences, and Martial Quality Among Spouses of Holocaust Survivors". Journal of Marital Family Therapy. October 2001, 433-444. For a strong overview of the various considerations and

tensions governing some of the calculations of the cost of PTSD see: Catey Hill, "What PTSD Costs Families". Marketwatch. April $4^{\text {th }}, 2014$. January $18^{\text {th }}, 2015 .<$ http://www.marketwatch.com/story/what- ptsd-costs-families-2014-04-04>.

${ }^{250}$ Paul Kennedy, The Rise and Fall of the Great Powers, (New York: Vintage Books, 1987) 278-279.
} 
modern era and industrial revolution. ${ }^{251}$

'The military values of patriotism, discipline, self-sacrifice and respect for tradition can be made part of an ideology which is used for other purposes. The values can be used to promote social solidarity and cohesion, encouraging people to unite against a common enemy. Such unity may be designed to over-ride conflicts of class, gender or ethnicity and mobilize the nation to service some higher objective ${ }^{\prime 252}$

This represents an enormous potential for socialization inherent in military participation and the military institution overall. At the early beginnings of the nationstate, the military and military service played a key role in strengthening national identity and the military was actively employed in order to improve national unity and the legitimacy of the nation-state.

'Quite apart from the public's approval of 'the military virtues' no other national institution so symbolizes independence, sovereignty or equality with other people's as a country's armed forces. The first thing a new nation creates is a national army. The army symbolizes, as well as makes effective, its distinctive identity. ${ }^{253}$

While still used for the purposes of identity-building to this day, the employment of military service to foster a sense of a national consciousness is often argued to have been pioneered by Napoleon during the Levée en masse of the 1790s when, 'suddenly war again became the business of the people- all of whom considered

\footnotetext{
${ }^{251}$ It is of little surprise then that the most militarily sophisticated state, Prussia, was also the first to adopt compulsory education in the modern era.

${ }^{252}$ Ron Smith, Military Economics: The Interaction of Power and Money, 29.

${ }^{253}$ Samuel Finer, The Man on Horseback: The Role of the Military in Politics, (London: Pall Mall Press, 2006) 33
} 
themselves to be citizens. ${ }^{254}$ From some of its earliest origins, the state, the nation, citizenship and the military have all been very closely intertwined.

Interestingly, some have proposed that, rather than the state appreciating the military for its nation-building capacity, as is most commonly accepted today, it was in the first place military necessity which acted as the impetus for nation-building. In other words,

'...that the need for military effectiveness may have facilitated nationalism in the nineteenth century. When the Napoleonic Wars demonstrated the superiority of the French mass army... (it was itself) a marked departure from the use of professional armies in the eighteenth century. In France and Russia in particular, nationalism was promoted to facilitate social acquiescence and participation in mass armies. ${ }^{255}$

Given that 'a critical aspect of nationalist culture is the identification of a collective identity and a stress on the importance of the collective over the individual. ${ }^{256}$ nationalist values can dovetail well into those of the military institution, which also must emphasize obedience and hierarchy. With this in mind, it seems altogether possible that nationalism was partly molded out of a desire to increase military effectiveness during a time of great need, recalling that modern nationalism arose alongside the French Revolution and subsequent Napoleonic wars. Sidestepping the debate on causality and leaving the question for other scholars, there is a more immediate debate as to the importance of nation-building and nationalism in the postmodern, post-imperial march-forward of human history, with some arguing that

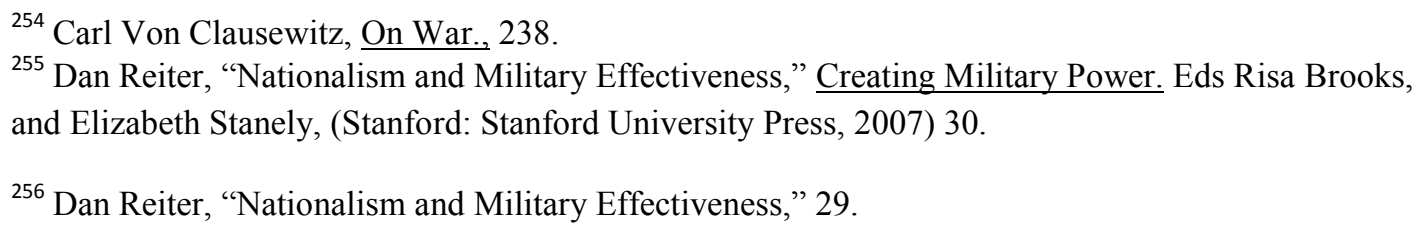


nationalism has been made obsolete by cosmopolitanism. A happy thought indeed, but when Michael Ignatieff skeptically looked for evidence to the cosmopolitanism of Sarajevo, he noted that,

'...it is only too apparent that cosmopolitanism is the privilege of those who can take a secure nation-state for granted... (cosmopolitans) are not beyond the nation; and a cosmopolitan, postnationalist spirit will always depend, in the end, on the capacity of nation-states to provide security and civility for their citizens. ${ }^{257}$

While there was a surge of post-Cold war idealism predicting the end of the nation-state, it would seem doubtful that the nation-state will be going away in short order. ${ }^{258}$ With that said, the military's role in building a sense of national identity continues to represent a spinoff so fundamental to statehood that it is simultaneously immeasurable and indispensable. The existence of shared identity, to which the military makes such an invaluable contribution, forms itself much of the basis for statehood.

The effectiveness of this spinoff, however, like so many of the human capital externalities associated with the military, is greatly dependent on rates of military participation and national composition. For example, an ethnically homogenous military in an ethnically heterogeneous state would be rather ineffective at nationbuilding or perhaps even counter-productive. In this formation, the one particular ethnic group from which the military is composed could come to be associated with an external state authority or could be resented for perceived political favoritism, thus

\footnotetext{
${ }^{257}$ Michael Ignatieff, Blood and Belonging, (Toronto: Penguin Canada, 1993) xxii-xxiii.

${ }^{258}$ Ignatieff associates this misplaced idealism in part with the fact that those with adequate time and resources to follow intellectual pursuits were wealthy (by global standards) Westerners, who themselves were living increasingly cosmopolitan lifestyles. In this context, it was far too easy to extend arguments to the undeveloped world and lower classes where their relevance was in fact quite marginal. (Michael Ignatieff, Blood and Belonging,)
} 
undermining national unity. There are many such examples of this which can be looked to in Sub-Saharan Africa, although Rwanda might provide the most infamous case, where the state and military were perceived to be a tool of the Tutsi. Yet the composition of the military will depend greatly on the style of recruitment that is employed, raising once again the importance of a comparative analysis of AVFs versus conscription.

Looking first to the AVFs with which we are likely more familiar in the present-day, there are some inherent limitations to this recruitment style's spin-off benefit to nation-building. Firstly, volunteer military service is substantially less likely to produce a military that is a representative sampling of the national composition, which in turn lessens its effectiveness at building a strong and broadly inclusive national identity. For one, the composition of AVFs are more dictated by income and social status, with a greater proportion of AVF recruits coming from lower socialeconomic classes due, in part, to the equality of opportunity permitted by the military. There are also elements of language, geography, culture, ethnicity and religion which play a role and can serve to limit the military's ability to spinoff nation identity. In Canada, Lt. Gen. (retired) Romeo Dallaire recounts the French/English divide in the 1960s and the,

'... military culture that lagged far behind the rest of the country in recognizing the rights and differences of French-speaking Canadians... The numbers (of recruits) enlisting from (Francophone Canada) was embarrassingly low; potential recruits... were repelled by an armed forces that was English-dominated and highly intolerant of FrenchCanadians... (I was told) that if I wanted to make the army my 
career I should change my name from Dallaire to Dallairds (because it sounded more English)..$^{259}$

Rather than acting as a source of national unity in this example, the overwhelming recruitment and composition of the military from one cultural community in a heterogeneous nation served to undermine the military as a source of nation-building. Even though AVFs are increasingly commonplace, they may be predisposed to a lesser nation-building spinoff than mandatory service systems, especially in the event that there is little in the way of employment equity considerations when undertaking recruitment.

It is therefore important to compare the impacts of AVFs to the original manifestation of nationalism and modern military participation, that is, conscription. Although often associated with universal mandatory military service, conscription actually entails a universal obligation to serve in the military if requested, and is better characterized by a randomization of recruit selection. When tailored to the goal of nation-building and national integration, conscription based militaries have a strong advantage over AVFs. In addition to being more representative of the society at large, they are more effective at building and transfusing a sense of nation-hood, especially in heterogeneous societies. ${ }^{260}$ While conscription is able to ensure a military composition that is more representative of the national fabric ${ }^{261}$ and thus more attuned to nationbuilding, it is still perfectly possible for a conscript military to take a form that it not

\footnotetext{
${ }^{259}$ Romeo Dallaire, Shake Hands with the Devil, (Toronto: Vintage Canada, 2004) 17-18

${ }^{260}$ Ronald Krebs, "One Nation Under Arms? Military Participation and the Politics of Identity," Security Studies. Spring 2005.

${ }^{261}$ While an improvement in the representativeness of the military's composition, conscription will still not necessarily result in a completely egalitarian or representative selection of recruits. This is because there are always exemptions for military service which are awarded to a certain degree along the lines of social status, with, for instance, the wealthy receiving a disproportionate share exemptions from military service due to university enrollment. Conscription does however result in much more equitable military participation than AVF.
} 
conducive to nation-building. For instance, in Iraq prior to the 2003 invasion, the Shia were generally viewed with suspicion by the predominantly Sunni military officers, and were thus conscripted almost entirely into low ranks and 'cannon fodder divisions'. This exacerbated existing social tensions, provoking national disunity and undermining military effectiveness on the battlefield. ${ }^{262}$

Militaries which adopt conscription as part of their recruitment strategy also have setbacks which detract from conscription's comparative appeal. Naturally this will depend on the exact type of conscription policy undertaken and what exemptions to military service are permitted. If the military is inflexible to the opportunity costs of military service and unwilling to make exceptions for productive activities, the opportunity costs of conscription can be staggering. Taking this to the point of absurdity was the Romanian military in the 1930s that continued with relatively indiscriminate conscription but at the same time, 'could not afford forage so instead of refining their training, units were instructed to participate on the largest possible scale in agricultural work on the basis of share cropping'. ${ }^{263}$ Taking people away from potentially crucial professions or studies to perform subsistence agriculture is clearly detrimental to long-term productivity and is far from worth the nation-building spinoff. A contrasting example might be the U.S. 'draft' where 'occupational deferments' were issued for university studies, essential professions and the like in order accommodate economic imperatives. ${ }^{264}$ While this system ensured that mandatory military service would have as limited an effect as possible on long-term economic prosperity, it also resulted in a disproportionate burden of military service for ethnic groups and social

\footnotetext{
${ }^{262}$ Timothy Hoyt, "Social Structure, Ethnicity and Military Effectiveness" Creating Military Power. Eds Risa Brooks, and Elizabeth Stanely, (Stanford: Stanford University Press, 2007) 59-76.

${ }^{263}$ Alexander Statiev, "When the Army Becomes 'Merely a Burden': Romanian Defence Policy and Strategy (1918-1941)," The Journal of Slavic Military Studies. June 200069.

${ }^{264}$ Timothy J. Perri, "The Evolution of Military Conscription in the United States," The Independent Review. Winter 2013, 434-434.
} 
classes that did not have access to these jobs or educational institutions. In this case, it is worth considering whether the economic stratification that resulted would have undermined or eliminated the nation-building spinoff. Thus, there is a trade-off that comes with increasing friendliness to economic imperatives, as a sense of social injustice can limit the effectiveness of the military in nation-building.

While it is certainly indisputable that military participation has the potential to accrue some indirect benefits by acting as an agent of nationalist acculturation, there may also be additional costs associated with the use of the military for nation-building. On the one hand, there are limits to nationalistic education in the military since, 'demonizing the enemy and inflating nationalism can create societal demands for aggression and warfare, even towards risky and ultimately doomed military ventures. ${ }^{265}$ Early $20^{\text {th }}$ century Japan may perhaps represent the best example of this, when aggressive nationalism contributed in large part to rampant militarism and a very costly decade of war. Certainly, a more tame civic nationalism ${ }^{266}$ has been argued to serve a constructive purpose, although the French Revolution was certainly not without its extremes. Suffice it to say, when taken to extremes, a military doctrinal overemphasis on nationalism may also be the source of social problems and instability, but when employed in moderation it can make a constructive contribution to the nationstate. Although a relationship between national culture and the military is of crucial importance when judging the effectiveness and value of the military as an instrument of nation-building, the impact of culture on '...operational and especially strategic

\footnotetext{
${ }^{265}$ Dan Reiter, "Nationalism and Military Effectiveness," 32

${ }^{266}$ Employing Michael Ignatieff's definition of civil nationalism as, '...maintain(ing) that the nation should be composed of all those - regardless of race, color, creed, gender, language or ethnicity- who subscribe to the nation's political creed... This nationalism is called civic because it envisages the nation as a community of equal, rights-bearing citizens, united in patriotic attachment to a shared set of political practices and values.' Michael Ignatieff, Blood and Belonging, xiii)
} 
issues remain understudied. ${ }^{267}$

With this diversity of roles, skills and training crucial to the military, any examination of military spin-offs must give ample consideration for military training practices and skills in their overall relationship to the national political economy. There is little doubt that 'human capital enhancement through supporting/subsidizing education can indirectly and positively affect the civilian sector.. ${ }^{268}$ The questions which tend to arise pertain to matters of degree and opportunity cost. At one extreme, the adoption of broad-based conscription and specialization in combat may produce a strong military, contribute the sense of nation-hood and produce a reserve of martial skills and discipline which contribute to overall stability in the state. This strategy would, however, come at great cost, not only financially but in terms of forgone opportunities and is only possible by leaning against the winds of long-term economic well-being. At the opposite extreme, the military could become a major contributor to economic prosperity as an agent of skills-training and human capital development, but perhaps only at the expense of civilianizing the military and destroying its key functionality as the protector of the state. In short, there are a basket of policies available that governing military skills training which require a careful balance in order to ensure that present military effectiveness is not sacrificed for economic spinoffs, nor that the economic realities governing the huge opportunity costs of the military are not ignored.

\footnotetext{
${ }^{267}$ Risa Brooks, "The Impact of Culture, Society, Institutions, and International Forces on Military Effectiveness," 7.

${ }^{268}$ Uk Heo, "The Relationship between Defence Spending and Economic Growth in the United States," 762
} 


\section{Chapter \#6}

\section{A Reconsideration of Military Spending}

'In the event of a nuclear attack, the 210 top people in the UK were to be spirited away by the military to a hideout under Box Hill. The military, who compiled the list of those to be saved, did not include anybody from the Treasury.'

Ron Smith (Military theorist and professor of economics) ${ }^{269}$

Occupying a special place among political institutions and wielding an

abnormally large economic endowment, the military plays a central role in the state's

political economy. When approaching the subject of military spending more

specifically, there is a clear underlying tension between the various stakeholders

involved in the process of military budgeting. Given the military's prominent role

within the national political economy, there should be little doubt as to why the

military budget routinely finds itself subject to the competing pushes and pulls of

political, economic and strategic imperatives. ${ }^{270}$ This is part and parcel of its central

position in the political economy of the state. A three-way dichotomy emerges between

the divergent interests of the political, the economic and the strategic, known in some

circles as an 'iron triangle ${ }^{\prime 271}$, which ultimately colours not only the results of military

spending but also of civil-military relations and the boundaries that exist between the

public and private economies. When there is a lack of balance in this three-way

\footnotetext{
${ }^{269}$ Ron Smith, Military Economics: The Interaction of Power and Money, 21.

${ }^{270}$ Indeed, there is speculation that even Eisenhower's famous formulation of the 'Military-industrial complex' originally included a third actor, 'Congress'. '"Few people realize this," his granddaughter Susan reveals, "but in the earlier drafts of the Farewell Address, the original configuration had not been military-industrial complex but rather military-industrial-congressional complex" Before Eisenhower gave the speech, Susan explains, he removed the word congressional because... he was afraid it might be misconstrued as a direct criticism against the sitting Congress.' (Eugene Jarecki, The American Way of War, 191-192)

${ }^{271}$ An American term to signify the relationship between Congress, a given bureaucratic entity and an interest group, or in this case represented by the terms 'political' (Congress), 'strategic' (bureaucratic interest of the military), 'economic' (interests).
} 
dichotomy, military spending policy is bound to produce suboptimal and disappointing results. Beyond inefficiency, the disproportionate influence of one element of the 'iron triangle' over the others comes with great dangers to the precarious balance of interests that compose the national political economy. While it is important to understand the problems afflicting military spending as well as ideal solutions, it is all for naught if the institutional arrangements which created these problems are left unaddressed.

\subsection{Understanding Civil-Military Relations}

When the subject of disproportionate military influence in economics and politics is broached, what most often comes to mind is usually an example that exists at the foremost extreme of the spectrum; military dictatorship. This is where the military has outright displaced and absorbed political institutions and has taken over the commanding heights of the economy. Although it is indelicate, to say the least, to equate undue military influence with the overt subversion of political processes and coup d'état, this phenomena is nonetheless an important historical reality that must be addressed before advancing an understanding of the more subtle degrees of military influence in the state political economy. While some may mistakenly view military interventionism as a modern or Westphalian phenomena,

'The experiences of Rome, of the medieval Italian city-states, of England under the Commonwealth and the Protectorate; the activities of such corps as the Mamelukes, the Janissaries, the Streltsi; all of these seem to attest to the antiquity as well as the perennialism of military intervention in politics. ${ }^{272}$

${ }^{272}$ Samuel Finer, The Man on Horseback: The Role of the Military in Politics, 205. 
When considering the monopoly of violence held by the military and the long history of military intrusion into the political sphere, the key question to ask should not be, 'why does the military sometimes encroach on political process?' but rather, 'why does the military not always seek to monopolize political control?' Indeed, it would seem to be well within the military institution's capabilities to retain a monopoly on political control and to oust (unarmed) civilian governments at their leisure.

While observers may take note of the volume of coups as they occur, remarking about their relative frequency, what is more fantastic is the frequency with which the military does not rebel against civilian control even while it has the power to do so. Consider, for instance, the case of Pakistan, where in its nearly 70 years of independent history, the country has had only one democratic transition of power that did not involve military intervention. ${ }^{273}$ Although perhaps the full extent of the military involvement in politics is demonstrated with exceptional transparency in Pakistan's case, it is the rule rather than the exception that civilian power is underwritten by the military and exists due to its acquiescence and continued validation of civilian authority. This ultimately represents an important insight to the old Weberian adage that statehood depends on the monopoly of legitimate violence, since this legitimate violence underwriting statehood arises from the military. Or, in its less delicate expression by Mao TseTung, 'political power grows out of the barrel of a gun'274 and the military has all the guns. With this lop-sided power dynamic in mind, perhaps the important question becomes why the military bothers with any semblance of civilian control of political power. Why does the military not simply take control of political

\footnotetext{
${ }^{273}$ Munir Ahmed and Nahal Toosi, "Pakistan marks first-ever democratic transition as new parliament sworn in," CTV News. June 1st, 2013. January 31st, 2015. <http://www.ctvnews.ca/politics/pakistanmarks-first-ever-democratic-transition-as-new-parliament-sworn-in-1.1306459>.

${ }^{274}$ Mao TseTung, "Problems of War and Strategy," Selected Works. Vol 2. November 6th, 1938. 224.
} 
power and the state, holding on to both in perpetuity? The answer is quite simply that the military does not see itself as an institution which exists to perform the functions of government any more than legislators and bureaucrats see their role as a function of fighting wars.

While the military may have the power to oust civilian governments, it does not naturally seek to do so, nor does it seek to accumulate political power for its own sake. This natural respect for institutional boundaries is perhaps best expressed by the founder of modern military theory, Carl Von Clausewitz, who wrote that, 'subordinating the political point of view to the military would be absurd, for it is policy that has created war. Policy is the guiding intelligence and war only the instrument, not vice versa. ${ }^{275}$ Today, at least in principle, both civilians and the military tend to be in fundamental agreement about the supremacy of civil rule. This is because, amongst other things, there are practical aspects to setting clear expectations and boundaries for the military. First and foremost, 'Military involvement in government may not only be damaging to the economy, but may make the military ineffective in combat as their goals are switched away from military objectives to domestic politics. Military governments have a poor record of winning wars. ${ }^{1276}$ It otherwise requires little explanation for why civilian leaders might prefer to retain control of the reins of the state since the opposite would mean a revision of their raison d'etre. Thus, civil and military leaders accept, at least in principle that civilians should remain in control of the military for the sake of both the civilian and military institutions. This means that 'good' civil-military relations are when institutional boundaries are respected and civilians are firmly in control of the

\footnotetext{
${ }^{275}$ Carl Von Clausewitz, On War, 254.

${ }^{276}$ Ron Smith, Military Economics: The Interaction of Power and Money, 29.
} 
military. With that said, civil-military relations are far from rosy and are described by one expert as 'ranging from normal, which is bad, to abnormal, which is very bad. ${ }^{277}$

If the subordination of the military to political power is such a clearly stated stipulation of the civil-military relationship, then what cause might there be for the military to encroach on political power, through a coup or otherwise? 'On closer examination (of the examples where the military has taken control of government), much of the military's enthusiasm for playing a political role is seen to spring from circumstances which either pander to or injure its pride as a particular corporation. ${ }^{278}$ In essence, disproportionate military influence in the political sphere is not a creeping military plot for political dominance, but a defensive reaction to a perceived institutional threat caused by a lack of civilian empathy for military objectives. As the military and civilian elements of the state have had a close relationship from the state's emergence, the military's perceived institutional interest often extends to state stability and the sustenance of state institutions. ${ }^{279}$ To use the 2014 Thai military coup as an example, the military viewed its responsibility to safeguard the stability of the state and the institutions that underpin it in what was considered a time of danger. ${ }^{280}$ Rather than accumulating power for power's sake, as some of the coup's detractors have argued, the

\footnotetext{
${ }^{277}$ Steve Saideman, “An Introduction to Civil-Military Relations," Carleton University - River Building, (Ottawa, Ontario. September $9^{\text {th }}, 2013$ ) Lecture.

${ }^{278}$ Samuel Finer, The Man on Horseback: The Role of the Military in Politics, 39.

${ }^{279}$ This leads to the all too common assumption that the military is an inherently conservative or 'right wing' institution since the military often acts with enthusiasm against revolutionary movements in order to safeguard state stability. This is a hasty conclusion. Military dictatorships themselves can be 'right wing' or 'left wing', depending usually on the rank of the military leader, with lower ranks tending to be more left leaning (ex. Colonel Qaddafi, Colonel Chavez) and higher ranks tending to be more right leaning (ex. General Zia-ul-Haq, General Pinochet). Furthermore, while the military has on occasion been guilty of adopting conservative social practices, such as 'Don't Ask, Don't Tell', the military has also been at the forefront of socially progressive policies, with the U.S. Army adopting limited racial desegregation well in advance of mainstream U.S. Society.

${ }^{280}$ Not insignificant to this case is that the monarchy, much revered as the embodiment of statehood and an respected arbiter in political conflicts, endorsed the military's actions in taking power.

Kate Hodal, "Thai King Endourses Army Chief as New Leader," The Guardian. May 26th, 2014. January 31st, 2015. <http://www.theguardian.com/world/2014/may/26/thai-king-endorses-army-chiefleader-military-coup>.
} 
Thai military's rush into the political arena is more likely to have come from a perceived threat to its core interests; stability, monarchy and the military institution, which is why it has 'returned to the barracks' after its coups with such regularity. In other words, there is always the risk of a coup when the military senses an existential threat due to the perceived incompetence of the civil government posing a risk to the state. ${ }^{281}$ While dramatic coups such as these are rarer in developed countries, this does not make the developed world immune to these underlying tensions at the heart of civil-military relations.

Even while there is an acceptance of civil authority, the military nonetheless retains its own interests and preferences, and if given the opportunity and the sense that these preferences are at risk, the military will more actively ensure that those preferences are enacted by civil leadership. Given that the military is the foremost expert in military matters, it possesses a unique ability to guide the formulation of the civilian policies that could govern the actions of the military. It is quite easy to conceive of examples where this information asymmetry and 'agent-principle dilemma ${ }^{1282}$ may begin to pose a problem to civil-military relations. The military may, for instance, exert its influence to sway the direction of civilian foreign policy, rather than remaining strictly an instrument of that policy. To point to a well-known case, the U.S. military and intelligence apparatus advised the civilian leadership of the U.S. in

\footnotetext{
${ }^{281}$ What constitutes 'incompetence' and 'threats to the state' according to the military have historically encompassed a wide range of policies. Some have more clearly understandable justifications than others, such the perception of communist take-over in Cold War Argentina in 1976 or the prospects of military catastrophe during the German 1944 putsch attempt. While these cases could easily be understood to represent existential threats, in other cases, matter which seem to be of clear civil authority, such as budgeting and budget cuts.

${ }^{282}$ The term 'agent-principle dilemma' refers to a scenario wherein one actor, the agent, is entrusted to make decisions on behalf of another actor, the principle. While the agent is trusted to make decisions in the best interests of the principle, the agent also has its own interests which tends to result in a situation where they seek to undertake actions that reconcile their interests with those of the principle, without jeopardizing their continued status as the agent.
} 
2003 that, having considered all of the evidence, Saddam Husain's Iraq represented such a profound and immediate threat that it merited a pre-emptive war. Once the civilian leadership committed to the conflict, conflicting evidence began to arise indicating that it had perhaps not been prudent to rely so heavily on the military's guidance, despite that institution's clear expertise in matters of war. ${ }^{283}$ For an example that is closer to home, Janice Gross Stein and Eugene Lang suggest in a national bestseller that the Canadian Forces employed their information asymmetry to maneuver decision-makers in Ottawa into a role in the Afghanistan War that was widely deprecated by the civilian leadership. ${ }^{284}$

Conversely, the military may find itself equally sensitive to different elements of civilian policy that encroach on, and interfere with, the military's proper jurisdictional mandate. While normally capable of presenting a united front to outside influences and ensuring the enactment of its preferences, 'military unity...is weakest in regard to... detailed political and economic development policies, because these normally lie outside the professional domain of the officers, and as such, outside the realm of unquestioning obedience or established military doctrine. ${ }^{285}$ This makes military budgets a tempting area for abuse of civil authority as military funding may be diverted to other objectives with relative ease and minimal outside scrutiny. In that sense, 'the (civil-military) problem in the modern (developed) state is not armed revolt but the relation of the expert to the politician. ${ }^{286}$ In other words, the agent-

\footnotetext{
${ }^{283}$ This is of course referring the presumed existence of weapons of mass destruction in Iraq. Although the evidence cited for their existence was described as a 'slam dunk', further examination in the years prior to 2003 have not been able to corroborate these claims.

${ }^{284}$ Janice Gross Stein and Eugene Lang, The Unexpected War: Canada in Kandahar, (Toronto: Penguin Canada. 2007).

${ }^{285}$ Alfred Stepan, The Military in Politics, (Princeton: Princeton University Press, 1974) 229.

${ }^{286}$ Samuel Huntington, The Soldier and the State, (Cambridge: Harvard University Press. 1957) 20.
} 
principle dilemma is far from being an abstract problem in developed countries today and civil-military relations may in fact be the prime mover from which other problems of military spending have stemmed.

\subsection{Civil-Military Relations in the Post-War Era}

These tensions at the heart of civil-military relations have changed through the progression of the $20^{\text {th }}$ and $21^{\text {st }}$ centuries with the Second World War again proving to be a critical moment. The frequent suggestion is that the Second World War ushered in an era of increased military centrality in public affairs, diminishing the comparative importance of civil decision-making. Pointing to the Pentagon as a metonym for the U.S. Military but also figuratively as a building, one commentator notes that, 'the Pentagon has virtually exploded in scale over the past sixty years... (it's) a perfect metaphor for the sea change from the emergency posture of World War II to the posture of permanent preparedness of the Cold War. ${ }^{127}$ The results of this increased role of the military has also been observed by the civil-military theorist Samuel Finer, who remarked (in 1962) that,

'Nowadays, deference (in decision-making) to the military... is commonplace. In the context of the 'cold war' it springs from the sheer size of national defence expenditure, which affects the whole national economy; from the increasing technicality of warfare, making much of it a matter for complicated specialisms; from the inability of civilian leaders any longer to assess military tactics and strategy as competently as in the past; from the fact that today's

\footnotetext{
${ }^{287}$ Eugene Jarecki, The American Way of War, 90.
} 
battlefields are entire countries or regions; and finally from the gruesome immediacy of the nuclear threat, which thrusts on some individual or individuals responsibility for a split-second military appreciation. ${ }^{288}$

In other words, if civil authorities continuously accede to military recommendations as a result of the increased complexity of war, then the proper boundaries of civilian authority over the military become eroded. Yet conversely, if the recommendations of the military in matters of war are ignored, it will be at the expense of military effectiveness and the ability to apply state power, a similarly undesirable result. Finer and others have argued that the unresolved dilemma of where to draw the line between civil and military realms of authority is the cause of the military's undue influence in civil decision-making. However, these post-war developments may not be so clearly favourable to military decision-makers as it would first seem since political power is seldom ceded willingly. Far more likely is that this expansion of military authority would result in a lengthy era of troublesome civil-military relations rather than producing any static relationship of one sort or another.

To examine this possibility more closely, it is important to look to examples of the supremacy of civilian authority over the military, particularly the military does not agree with civilian policy choices. This is because 'the best indicator of the state of civilian control is who prevails when civilian and military interests diverge. ${ }^{.289}$ Looking to one of the most controversial military policies of the past hundred years for evidence, we can return to the divergence of civilian and military preferences on

\footnotetext{
${ }^{288}$ Samuel Finer, The Man on Horseback: The Role of the Military in Politics, 74.

${ }^{289}$ Michael Desch, Civilian Control of the Military: The Changing Security Environment, (London: Johns Hopkins University Press, 1999) 4.
} 
recruitment. This great debate ultimately comes down to whether militaries should recruit through mandatory (conscription) or volunteer (AVF) service. With civilians tending to prefer AVF and militaries tending to prefer conscription, firm civilian control of the military would be evidenced by the decline of conscription in favour of AVFs. While conscription was the policy of most developed countries following the Second World War, this began to gradually change in the 1970s, with widespread conversion to AVFs by the 1990s. Looking to the annual Economic Freedom of the World report, which ranks 141 countries on their commitment to conscription, amongst other things, we can clearly examine the global decline of conscription. With a score of ' 10 ' representing a purely AVF military and ' 0 ' representing a very heavy conscription burden, the world's average score in 1970 was 3.0. By 2009, that average had increased to 6.3 , indicating a significant decrease in conscription-oriented policies over this period, or a near doubling of AVFs globally. ${ }^{290}$ Most of this conversion to AVFs occurred in the global North, clearly against military preferences, and is indicative of clear civil supremacy during the Cold War era until at the 1990s.

This relationship between civilian and military authorities did not remain static and beginning in the 1990s, 'some (began) to argue, that since the abolition of the draft...civilian and military political and social attitudes have increasingly

\footnotetext{
${ }^{290}$ Joshua Hall, “A World-Wide Decline in Conscription: A Victory for Economics?" Library of Economics and Liberty. October 3rd, 2011. January 31 2015. $<$ http://www.econlib.org/library/Columns/y2011/Hallconscription.html $>$.

Karl Haltiner and Tibor Tresch, "New Trends in Civil-Military Relations: The Decline of Conscription in Europe," Inter-University Seminar on Armed Forces and Society. Palmer House Hotel, Chicago. 26-28 October 2007.

$<$ http://www.vtg.admin.ch/internet/vtg/de/home/schweizerarmee/organisation/hkaneu/milak/militaer wis _

senschaftliche/militaersozioligie/publikationen.parsys.93405.downloadList.13761.DownloadFile.tmp 15 13haltinerszvircsevnewtrendsincivilmilitaryrelations.pdf $>$.
} 
diverged. ${ }^{291}$ This is of course exactly what occurred as civil and military interests began to diverge in the early 1990s. When the threat environment of the Cold War era faded away, so did much semblance of harmonious civil-military relations, and the military began to chafe against civil authority and policies.

'The markedly less challenging post-Cold War international security environment witnessed mixed civilian control of the military. On the one hand, the civilian leadership succeeded in getting the military to accept significant reductions in defence spending...On the other hand, in comparison to the Cold War period, there have been more instances when military preferences have prevailed (over civilian preferences). ${ }^{292}$

While in most instances this deterioration of civil military relations was nonviolent and unspectacular, this era of great change was not without its dramatic outliers. The attempted 1991 coup d'état in Russia, and the politicization of the Russian military during the 1993 constitutional crisis both spotlight the declining civil-military relations of the $1990 \mathrm{~s} .{ }^{293}$ In the rest of the developed world, particularly the United States, the civil-military disharmony was substantially less visible but no less significant.

'One might ask why... this issue is not more prominent in the public debate... First, civilian leaders, especially those in the Clinton administration, have little interest in publicizing their ongoing

\footnotetext{
${ }^{291}$ Michael Desch, Civilian Control of the Military: The Changing Security Environment, 10. ${ }^{292}$ Michael Desch, Civilian Control of the Military: The Changing Security Environment, 31.

${ }^{293}$ While in the 1993 example, the Russian military did not engage in a coup d'état, strictly speaking the military does not need to oust a government in order for its actions to constitute an undue interferance in the political realm. In this case, the military declared its neutrality to the crisis before eventually choosing to back Boris Yeltsin's bid for power instead of that of Alexander Rutskoy. The result is that the military effectively chose the leader of Russia.
} 
problems with the American military because these problems make the civilian leaders look weak. Second, the (American) military also does not want to highlight this weakening of civilian control because the notion of subordination to civilian authority is so deeply embedded in its professional culture that it is difficult for most military officers to admit publicly their changed attitudes to civilian control... Third, the (U.S.) public's interest in military issues has waned dramatically since the end of the Cold War, so the short-term consequences of this weakening in civilian control of the military are not readily apparent. ${ }^{294}$

While the debate between AVFs and conscription parallels these broad changes in civil-military relations, it may also represent a symptom of deeper changes in the political economy of military spending. In other words, the independent variable governing civil- military relations may be the conditions of the broader political economy of the state and how the military relates to them. A close reading of the chronology of civil-military relations indicates a close overlap between civil-military trends and the rise and fall of the two major political-economic eras of the $20^{\text {th }}$ century. It is unlikely a coincidence that the heyday of conscription-based recruitment tends to overlaps with that of Keynesianism, while the rise of AVFs broadly shadows the rise of neoliberalism. Indeed, this should be of little surprise when considering that the move from conscription to AVFs was effectively an invitation of market factors into a realm where they were previously forbidden, a classic symptom of the transition into neoliberalism and also representing the growing predominance of market factors in

${ }^{294}$ Michael Desch, Civilian Control of the Military: The Changing Security Environment, 2. 
military policy. Living now in an era when market factors are the dominant forces of the national political economy, we can expect the relationship between the military and the market to have become similarly dominant in civil-military relations.

\subsection{The Market and the Military}

While the most striking and visible manifestations of disharmony in the Iron Triangle may be the civil and institutional contests facing the military, there are equally significant difficulties in the relationship between the military and market forces. Indeed, as referenced in this chapter's epigraph, the relationship between the military and economic forces may be particularly fierce and unforgiving, with a long history of troubled relations between the two. This is because the core interests of each entity are set in opposition with one another. Through a financial lens, military preparedness that is never employed in a conflict has return on investment of zero, and has been a waste of resources. From a military perspective, commercial endeavors and return on investment are trivial in the absence of the stability and security guaranteed by the military. Effectively, both entities have an institutionalized difficulty in valuing the other's priorities, making for an uneasy cohabitation when their authority overlaps in the arena of military budgeting. As far as the military is concerned, the goal of defending the state and its interests seldom conducive to compromise or to drives to make small economies. In contrast, the captains of industry are similarly disdainful of the non-economic decisions driving military policy and what they perceive often to be an exceptionally unproductive use of resources. This antagonistic relationship between finance and the military has defined much of the history of military budgeting.

Pioneering a contemporary discussion of this relationship between financial and 
military imperatives, Jonathan Kirshner argues that this disposition of finance against the military may stem from the economically motivated distaste for war and the conditions which accompany it. He writes, '...the financial community's aversion to armed conflict is a residual of its basic disposition in favour of macroeconomic stability. ${ }^{295}$ In other words, the macroeconomic conditions that often accompany war, including high inflation, price controls, expropriation and collapse of international trade, are profoundly detrimental to the core objectives and well-being of finance. Therefore, Kirshner suggests that, 'as a general rule, finance will be among the most cautious and reluctant to risk and initiate war. ${ }^{296}$ The case can be made that this financial distaste for war has spilled over into military budgets more generally, even of peacetime budgets. Although there is valuable 'good' produced by peacetime military capability, namely the ability to deter and coerce rivals, a financial position would likely perceive danger in any military spending since, 'if (a country) has military capabilities, it may wander into some kind of operation. ${ }^{297}$ In other words, finance perceives military spending to represent a liability in that military budgets could effectively draw financial entities into their condition of least preference, war. Similarly, with these budget cuts occurring with marginal regard for the threat environment or the need for defence as understood by the military, it should be of little surprise that financial retrenchment often comes into direct conflict with the military's core mission.

In addition to diverting resources away from supposedly unproductive uses, low military budgets themselves are thought to reduce the probability of conflict by

\footnotetext{
${ }^{295}$ Jonathan Kirshner, Appeasing Bankers: Financial Caution and the Road to War, (Princeton: Princeton University Press, 2007) 9

${ }^{296}$ Ibid

${ }^{297}$ Douglas Bland, "Everything Military Officers Need to Know About Canadian Defence PolicyMaking In Canada Advance or Retreat?" Canadian Defence in the 21 ${ }^{\text {st }}$ Century. 2005. 19
} 
financial elites. This interpretation of military spending is rather consistent with classical liberal theories and indeed it is true that high levels of military spending occur more often in times of war than in times of peace. However this relationship between low levels military spending and low levels conflict is a careless oversimplification of international relations and risks confusing association with causation. While military spending is certainly higher during war, this does not mean that more military spending itself is the cause of war. In fact, there is a strong case for the opposite relationship to be true. ${ }^{298}$

There are plenty of situations to illustrate this, but Kagan perhaps makes the most persuasive case. In the lead-up to the Second World War, Germany was faced with rebukes of its aggression by British politicians while Britain simultaneously reduced its military budget sharply. German decision-makers interpreted actions to speak louder than words and thus understood these rebukes to be mere political theatrics intended for the British audience. Germany understood Britain's cuts to the military budget to signal acquiescence in German aggression with a wink and a nudge. In reality, the decreased British military budget stemmed from unrelated concerns of economic efficiency and financial pressures, and did not represent a lack of commitment to the situation in Europe. Nevertheless, this misappraisal of power caused by imprudent budget cuts brought Germany and Britain into a war with one

\footnotetext{
${ }^{298}$ Kagan presents a holistic theory contrasting this idea which, although secondary to the immediate work, is quite valuable when considering the relationship between military spending and war. Kagan ultimately suggests that the build-up and exercise of military power incommensurate with other measures of state power (financial, cultural etc.) has been the result of most of the world's gravest conflicts. With states only committing to military contests which they can reasonably expect to win, the result should be the relative absence of wars, especially wars of attrition. Kagan's theory of war therefore conceptualizes war as the result of either over-extension or under-extension of military power relative to capabilities.

Donald Kagan, On the Origins of War: And the Preservation of Peace, (New York: Double Day Books, 1995).
} 
another that could have been avoidable through implementing less radical alterations to military spending. ${ }^{299}$ In other words, reductions in the military budget can be the direct cause of war! Regardless of the evidence, the idea has proliferated in financial circles that lower military budgets can be equated with a lower propensity for war. It is certainly doubtful that the military would agree with this assessment, to say the least. These differences of interpretation, among others, put military and financial interests in strong opposition to one another and bring them consistently into heated, and sometimes violent, conflict on matters of military budgeting.

Kirshner identifies several strong examples of these conflicts of military budgeting which illuminate the degree to which these institutions possess opposing objectives. In interwar France for example, fiscal policy was set according to the predominance of the financial imperatives at the time and as a reaction to the preceding years of economic turbulence. The result was that, 'defence spending was gutted in an effort to balance the budget....Between 1933 and 1938, German defence spending would practically triple France's's00 to the strong objections of the French military and without regard for predictions of impending catastrophe. This period was followed by France's decisive military defeat at the hands of Germany, as clear an indication as any that the cuts to the military budget were undertaken without respect for military decision-makers, resulting in a clearly inadequate military strength for the threat environment. During the same time period at the opposite end of the world, 'the Finance Ministry become the only important source of resistance to the military in

\footnotetext{
${ }^{299}$ Donald Kagan, On the Origins of War: And the Preservation of Peace, 281-436

${ }^{300}$ Jonathan Kirshner, Appeasing Bankers: Financial Caution and the Road to War, 108
} 
$\mathrm{Japan}^{1301}$, repeatedly refusing increases to the military budget in spite of the overwhelming militarization of Japanese society. This financial opposition to increased military budgets was so stalwart, yet so hopelessly irresponsive to the changing political conditions, that it only ended with the 1936 assassination of Finance Minister Takahashi by military officers in an attempted coup. Indeed the irreconcilable opposition between these two institutions is so strong that even today, '...most ministries of defence see their main enemy not as the country they might fight, but the finance ministry that controls their budgets and the audit office that evaluates their expenditures and publicizes their mistakes. ${ }^{1302}$

With the rise of Neoliberalism in the 1980s and 1990s, these contrasting interests of military and financial leaders were brought in to more direct contest. It is not surprising that civil-military relations would disintegrate at this time since neoliberalism represented the revived centrality of financial considerations in state governance which meant looming cuts to the military budget. While state budgets shrank almost universally during this time, and certainly no government entity enjoys having its budget reduced, the effect of neoliberalism on military budgets was especially dramatic. The Canadian forces, for instance, experienced, 'a twenty-three percent cut in the defence budget from $1993-1998^{1303}$ and in military circles, the 1990s are often referred to as the 'Decade of Darkness' as the military institution was eviscerated by a lack of funding. Even in the 1995 James Bond film 'Goldeneye', the new, sleek, efficiency-oriented ' $\mathrm{M}$ ' and the former military officer, James Bond, are deeply antagonistic to one another due to 'M's' focus on financial metrics. ${ }^{304}$ It would

\footnotetext{
301 Jonathan Kirshner, Appeasing Bankers: Financial Caution and the Road to War, 83

${ }^{302}$ Ron Smith, Military Economics: The Interaction of Power and Money, 7

${ }^{303}$ Joe Jockel and Joel Sokolsky, "Lloyd Axworthy's Legacy: Human Security and the Rescue of Canadian Defence Policy," Canadian International Council. 2000/2001. 4.

${ }^{304}$ Goldeneye. Dir. Martin Cambell. Perf. Pierce Brosnan, Judi Dench. MGM, 1995. Film.
} 
seem that civil-military relations following the Cold War were so poor as to make their way into popular culture and indeed, neoliberalism and the military possess widely divergent interests.

\subsection{Conclusions}

The military has a special role within the state system that sees it thrust into a position at the centre of competing interests, where it is used to remedy the malaises inherent to statehood. This makes the military budget a permanently strong candidate for inefficiency and underperformance. All other things held equal, the economic impact of military spending tends to be less than it would be for an equivalent amount of non-military expenditure. Despite the strong prevalence of myths to the contrary, military spending is a less-than-ideal vehicle for economic or industrial policy and is, at best, a benign form of government spending. Put otherwise, while military spending may be necessary in and of itself, military spending is not a driver of economic growth. With that said, military spending performs indispensable functions of statehood which cannot be discounted or ignored. The fact that the military underwrites state power and stability is well-established, but it is important to note that military spending itself also underwrites functions critical to the state. As the military may substitute for elected government or police in times of emergency, so does the military budget provide avenues for the spending which binds nation-state together regardless of whether it has been approved through proper channels and by legitimate political process. In many cases the observed inefficiencies of military spending is a direct result of this function, with military budgets providing the means for political pork, patronage and other substitutes of good governance.

In the $21^{\text {st }}$ century, the political economy of state military spending has 
become even more of a challenge and is clearly suboptimal compared to historic norms. The symptoms of the military's ill-fitting relationship within the state range from chronic economic inefficiencies in its budget, poor results for social policy and a disproportionate contribution to the sclerosis of political process. Yet this is not to suggest that these are qualities inherent in the military, in fact quite the contrary; the military serves an important role that cannot be overshadowed by any well-deserved skepticism about its present-day effectiveness. The military underwrites much of the state institution and continues to play a pivotal role in its political economy. While some are optimistic about the emergence of a post-state political-economic system where the military may not be necessary, it is important to recognize that at present, the state remains the central node of the political economy as a whole and will continue to do so for the foreseeable future. This makes military spending a question for today. Ultimately, there is no reason to expect military spending to be as permanently inefficient as it is now; the factors at the root of this inefficiency are historically contingent and the problem is perfectly solvable. With that said, there are major adjustments that will prove necessary to bring the military into a role better suited to achieve its ideal economic, political and strategic effectiveness and the central thrust of this work has ultimately been to define what share is the optimal share of economic and political power that should be assigned to the military institution.

At the heart of this question are the cut-throat and competitive relationships between the divergent interests of the 'Iron Triangle'. While relations between the political, the economic and the strategic are often heated, it is worth recognizing that like a three-legged stool, each element relies on the other. Indeed, all of these interests 
recognize the importance of one another and seek mastery of their own realm, leaving the fundamental difficulty in these relationships as one of having healthy and respected boundaries between them. Good fences can make for good neighbours. To begin with what has gone wrong, there has been a near century of ebb and flow between the division between civilian and military realms of authority to the point where impermanent and unclear divisions of authority have become the new norm. This has only gotten worse since the Cold War and new mandates are often determined on an ad-hoc basis by infighting, rather than a mutual respect and appreciation for differing areas of competence. This is a difficult problem that must be exposed to the light of day. Policy-makers and scholars, whether they be military or civilian, must be willing to recognize their mutual responsibility to, and advantage in, moving beyond the difficult relationships of the past.

First, unleashed demands for economic performances from the military institution, which holds non-economic factors as central, have doubtlessly resulted in some serious inter-institutional disharmonies - especially aggravated during the 1990sthat need to be resolved. Indeed, the emergence of neoliberalism perhaps unsurprisingly overlaps with the accelerating deterioration of civil-military relations previously outlined. It was also during this time that the search for military spinoffs, although having originated much earlier ${ }^{305}$, regained a prominent place in the public debate. Perhaps the greatest bellwether of this trend for demanding 'spinoffs' would be the Clinton administration's emphasis on 'dual use' military R\&D funding in the 1990s, where a financially eviscerated military was also expected to produce useful civilian

\footnotetext{
${ }^{305}$ Theorists were aware of, and actively sought to understand (albeit crudely) military spinoffs as early as the pre-Napoleonic Era.

Clive Trebilcock, “'Spinoff” in British Economic History: Armaments and Industry 1760-1914,"” The Economic History Review. 474-490.
} 
inventions from its already insufficient budget. Of course, there are many other culprits in the overemphasis of military 'spinoffs' and it should be said that 'spinoffs' (military or otherwise) are a fundamentally valid concept that have an important purpose in public discourse and research. Yet, much of the conversation about 'military spinoffs' has been appropriated by self-interested advocacy and unscientific analysis. In spite of highly charged arguments in support of spinoffs, it would appear that much of the mythology surrounding the productivity and spinoff benefits associated with military spending continue to circulate unchallenged. Therefore, the first major conclusion of this work is this: military spending can yield an economic spinoff, but that spinoff is typically of a lesser value than if the same amount of spending had been conducted through other channels. While military spending is certainly able to yield spinoffs benefits that are valuable and valued, to suggest that these spinoffs are themselves a good justification for military spending is a catastrophic mistake.

Some within the military may be tempted to buy-in to the productive spinoff thesis in order to advocate for increased funding for the military. While appealing, especially in the neoliberal era and having emerged so recently from the 'Decade of Darkness', this too is a mistake. Even though there may be value to the economic byproducts of military spending, employing military spending for the sake of creating these economic by-products is as confused as buying a new car for its value as scrap. As a new car should be purchased in order to be driven, so should military spending be used for the sake of increasing military effectiveness and not for creating economic spinoffs. The military's core competency is as the profession at arms, and the overemployment of the spinoff argument opens the door for more civilian policy demands and objectives to be placed upon the military. These demands regularly include practices such as hiring for 
considerations of regional equalization instead of military effectiveness, delivering legal trade subsidies through military procurement, locating military operations according to the priorities of political 'pork' and determining the military's operational and strategic requirements as a function of industrial R\&D priorities. At some point in the $20^{\text {th }}$ century, these types of civilian priorities have gained a disproportionate weight in the military budget and priorities, hijacking the military's mandate. This needs to change.

Not only is this change important for the sake of military effectiveness but also for the quality of the 'hijacking' institutions as well, which have sought to capture a share of the military budget for themselves. Using justifications of improving economic efficiency and generating spinoffs, civilian outsiders have been able to use military budgets as a safe harbour from the rigors of public scrutiny and economic tumult. This harbour has now become very crowded and the military budget is overloaded with the most uneconomic and cynical policies of government, turning the military budget into the whipping boy of government inefficiency. Not only does this have dire consequences for military effectiveness but it also permits these non-military actors to circumvent their legally defined roles. This contributes to the deterioration of their own effectiveness as the incentives for capture are greater than those for the legitimate execution of their mandates. Indeed, it's likely that resolving the problem of military budgets would increase the dynamism of government institutions far beyond the direct implications for the military. To this end, there needs to be recognition that the military institution is particularly vulnerable to the competing and contradictory objectives of disparate civilian institutions, which may justify their capture of military spending initiatives in terms of increasing economic productivity and 'spinoffs'. With all of this in mind, the second major conclusion is that there is an institutional necessity for the 
military to be sheltered, or at least insulated, from the types of economic considerations that affect the rest of government. While it is clear that the military is capable of acting on civilian economic considerations in a manner that is productive and beneficial for the rest of the national political economy, this objective must be relegated to the sidelines of military policy and buried deep within the military leadership's own discretion. Potential spinoffs cannot be, to any degree, a condition for reliable funding. A final recommendation is that, in addition to more clearly defined institutional boundaries, such as giving the military much stronger discretion over the use of its budget; there is also an attitudinal shift that must take place in military affairs. Although this work has made copious use of the civilian-military distinction and while its use is a reality today, this distinction is fundamentally not constructive.

Traditionally, military service has been intimately tied to the concept of citizenship, but today this relationship is often forgotten, with 'civilians' being separated from military service-people. The fact is that military service is a deontological function of citizenship and an equalizer of condition as much as is citizenship itself. While we should be grateful that recent geopolitical circumstances have only required a small portion of society to take up arms, something important was lost as society and the military became increasingly estranged from one another. Whereas in 1946, it was quite common for a household to have one or several members who had participated in military service, in 2015, it is far less common for citizens to have any first-hand connection with the military. Many today would be surprised to note that, despite the military's relegation to the sidelines of daily life, military participation still remains in the 'dusty fine print' of civic responsibilities as much as does the more quotidian 
responsibility of paying taxes. Indeed, it is worth noting that the decline in civilmilitary relations roughly shadows these declines in overall rates of military participation and the military's relative relegation to the background of society.

This is not to suggest that society must become increasingly bellicose or militaristic in order to mend fences with the military; the decline in inter-state war since 1945 remains a cause worthy of celebration. Yet the decline in military participation and war has occurred without a commensurate reassessment of the military's special seat in the club of state institutions. Put more simply, without a central role in society, the military cannot have a central role in the political economy or within the state. Some countries, like Costa Rica, have sought address this unbalance between legal status and reality by undoing the military's historic centrality to the state and political economy. They have done this by relegating the military to a function comparable to that of regular police, removing the military's special characteristics and defining its role as 'civic defence'. Others, such as Austria or Switzerland, have taken a different approach and have sought the continuation of the military's traditional role in society and political economy of the state but by adapting it to the present circumstances. These countries have continued with compulsory national service but addressed the declining external threat environment by bifurcating conscription into military service and 'civil service' (Zivildienst), where participants spend an equivalent amount of time doing social work (in a hospital, retirement home etc.). There not a one-size-fits-all solution and the course of action taken will depend very much on the particular circumstances by which each country is governed. With that said, many countries will find a movement towards either of these two models to be necessary. 
Whatever courses of action are chosen for military reform, it is important not to extrapolate the present conditions of peace too far into the future when doing so. This is not the first time in history that war has been widely believed to be obsolete or irrelevant, nor will it be the last. History is long and people are forgetful; indeed the permanent end of war was widely (and mistakenly) heralded twice just in this past century- after WW1 and after the Cold War. While it is important to be hopeful about the future, our optimism must fall short of utopianism. Gwynne Dyer warns that, 'We are a very lucky people - but we need to use the time we have been granted wisely, because total war is only sleeping. All the major states are still organized for war, and all that is needed for the world to slide back into a nuclear confrontation is a twist of the kaleidoscope that shifts international relations into a new pattern of rival alliances... We may inhabit the Indian summer of human history, with nothing to look forward to but the "nuclear winter" that closes the account... But change is certainly possible, provided that we understand the nature of the institution that we are trying to change and are willing to accept the consequences of changing it. ${ }^{306}$ The military remains an important institution whose form has dramatic implications for the political economy. We must be thoughtful about the role we choose for the military, since history has proven it to be a pivotal component of society's future.

\footnotetext{
${ }^{306}$ Gwynne Dyer, War, 1-2
} 


\section{Bibliography}

Achauer, David. "Public Investment and Productivity Growth in the Group of Seven."

Federal Reserve Bank of Chicago, Economic Perspectives. September Issue. (1989): 1725.

Ahmed, Munir and Toosi, Nahal. 'Pakistan marks first-ever democratic transition as new parliament sworn in.' CTV News. June 1st, 2013. January 31st, 2015.

$<$ http://www.ctvnews.ca/politics/pakistan-marks-first-ever-democratic-transition-asnew- parliament-sworn-in-1.1306459>.

Alesina, Alberto et al. 'A Model of the Political Economy of the United States.' The American Political Science Review. Vol 87. No 1. (March 1993) pg 12-33

Eds. Aligica, Paul and Weinstein, Kenneth. "The Essential Herman Kahn: In Defence of Thinking." Lanham: Lexington Books, 2009.

Atkinson, Robert. "Defence Spending Cuts and Regional Economic Impact: An Overview." Economic Geography. Vol 69. No 2. (April 1993) pg 107-122

Auerswald, David and Saideman, Stephen. NATO in Afghanistan: Fighting Together, Fighting Alone. Princeton: Princeton University Press. 2014. Print.

Berger, Robert. "Nazi Science - The Dachau Hypothermia Experiments." The New England Journal of Medicine. 1990. 322.

Biddle, Stephen. "Explaining Military Outcomes." Creating Military Power. Eds Brooks, Risa and Stanely, Elizabeth. Stanford: Stanford University Press. 2007.

Bland, Douglas. 'Everything Military Officers Need to Know About Canadian Defence Policy-Making In Canada' Advance or Retreat? Canadian Defence in the 21st Century. 2005.

Bland, Douglas. Time Bomb. Toronto: Dundurn, 2014. Print.

Blyth, Mark. Austerity: The History of a Dangerous Idea. Toronto: Oxford University Press, 2013. Print.

Boyne, Walter J. Clash of Wings: World War II in the Air. New York: Simon and Schuster. 1994. Print.

Brodie, Bernard. The Absolute Weapon. New York: Harcourt, Brace. 1946.

Brooks, Risa. "The Impact of Culture, Society, Institutions, and International Forces on Military Effectiveness." Creating Military Power. Eds Brooks, Risa and Stanely, Elizabeth. Stanford: Stanford University Press. 2007. 
Brooks, Rosa. 'No Army for Young Men'. Foreign Policy. September 27th, 2012. January 18th, 2015. < http://foreignpolicy.com/2012/09/27/no-army-for-young$\underline{\mathrm{men} / \mathrm{s}}$.

Burnett, Bob. "Why we Should Reduce the Defense Budget." Huffington Post. April 19th, 2013. < http://www.huffingtonpost.com/bob-burnett/why-we-should-reducethe- b $3115515 . h$ tml $>$. November 15th, 2013.

Butler, Smeadly. War is a Racket. Port Townsend: Feral House, 2003. Print.

"Canadian Forces Jobs." Canadian Forces. Canadian Forces. nd. Web. $2014<\underline{\text { http://www.forces.ca/en/jobexplorer/browsejobs-70 }}>$.

Chaikin, Andrew. "Live from the Moon: The Societal Impact of Apollo." The Societal Impact of Spaceflight. Eds. Dick, Steven and Launius, Roger. Washington: U.S. Government Printing Office. 2007.

Chase, Steven. 'F-35 costs at least $\$ 10$ billion higher than Ottawa estimates, expert says." The Globe and Mail. April 28th, 2014. <

http://www.theglobeandmail.com/news/politics/f-35-costs-could-double-over-programslife-expert-says/article18325378/>.

Coates, Kenneth. 'Preface'. The Alaska Highway. Coates, Kenneth. (ed.)

Vancouver: University of British Colombia Press. 1985.

Cothren, Richard. 'A Model of Military Spending and Economic Growth.'

Public Choice. Vol 110. No 1/2. (2002) pg 121-141

Dallaire, Romeo. Shake Hands with the Devil. Toronto: Vintage Canada. 2004. Print.

Desch, Michael. Civilian Control of the Military: The Changing Security Environment. London: Johns Hopkins University Press. 1999. Print.

Dumas, L. J.. 'University Research, industrial innovation and the Pentagon.' Turmin, L. (ed) The Militarization of High Technology. Cambridge: Ballinger Press. 1984.

Dunigan, Molly. 'A Lesson from Iraq War: How to Outsource War to Private Contractors'. Rand Corporation Blog. March 19th, 2013. January 18 th, 2015.

$<$ http://www.rand.org/blog/2013/03/a-lesson-from-iraq-war-how-to-outsource-warto- private.html $>$.

Dyer, Gwynne. War. Toronto: Random House, 1985. Print.

Edgerton, D.E.H. 'British Scientific Intellectuals and the Relations of Science, Technology and War.' Boston Studies in the Philosophy of Science. Vol. 180. 1996. 
Eisenhower, Dwight D. "Farewell Address by President Dwight D Eisenhower", Public Papers of the Presidents, 1960. Pg 1035-1040

Fanon, Franz. The Wretched of the Earth. New York: Grove Press, 2004. Print.

Farrell, Theo. "Global Norms and Military Effectiveness." Creating Military Power. Eds Brooks, Risa and Stanely, Elizabeth. Stanford: Stanford University Press. 2007.

Ferguson, Niall. The Cash Nexus: Money and Power in the Modern World. New York: Basic Books. 2001. Print.

Finer, Samuel. The Man on Horseback: The Role of the Military in Politics. London: Pall Mall Press. 2006. Print.

Frankl, Victor. Man's Search for Meaning. Boston: Beacon Press. 1959. Print.

Garfinkel, Michelle. 'The Economic Consequence of Reducing Military Spending.' Federal Reserve Bank of St. Louis. (November/December 1990) pg 47-58

Germain, Randall. Global Politics \& Financial Governance. New York: Palgrave McMillan. 2010. Print.

Goldeneye. Dir. Martin Cambell. Perf. Pierce Brosnan, Judi Dench. MGM, 1995. Film. Graham, Daniel. 'Heraclitus'. The Stanford Encyclopedia of Philosophy. (2011) ed. Zalta, Edward. <http://plato.stanford.edu/archives/sum2011/entries/heraclitus/>.

Green, John and Green, Hank. "Migrations and Intensification." Video. Crash Course. Youtube. November 26th, 2014. December 9th, 2014, < https://www.youtube.com/watch?v=Oy2XJMczUNc>.

Greenburg, Maurice. "Trends in U.S. Military Spending." Council on Foreign Relations. June 28th, 2011. Pg 1-8

Griffin, J. L. et al. 'The political economy of military spending: evidence from the United States.' Cambridge Journal of Economics. Vol 6. (1982) pg 1-14

Grossman, Dave. On Killing: The Psychological Impacts of Learning to Kill in War and Society. New York: Little Brown, 2009. Print.

Gross Stein, Janice and Lang, Eugene. The Unexpected War: Canada in Kandahar. Toronto: Penguin Canada. 2007. Print.

Hall, Joshua. 'A World-Wide Decline in Conscription: A Victory for Economics?' Library of Economics and Liberty. October 3rd, 2011. January 31st, 2015. $<$ http://www.econlib.org/library/Columns/y2011/Hallconscription.htmll . 
Haltiner, Karl and Tresch, Tibor. 'New Trends in Civil-Military Relations: The Decline of Conscription in Europe.' Inter University Seminar on Armed Forces and Society.

Palmer House Hotel, Chicago. 26-28 October 2007.

$<$ http://www.vtg.admin.ch/internet/vtg/de/home/schweizerarmee/organisation/hkaneu/mi $\underline{\text { lak/. }}$.

militaerwissenschaftliche/militaersozioligie/publikationen.parsys.93405.downloadList.13 761.DownloadFile.tmp/513haltinerszvircsevnewtrendsincivilmilitaryrelations.pdf $>$.

Hartley, Keith. "The Case for Defence." Defence and Peace Economics. Vol. 21. No. 5-6. (2010): 409-426.

Hartley, Thomas and Russett, Bruce. "Public Opinion and the Common Defence: Who Governs Military Spending in the United States?" The American Political Science Review. Vol 86. No 4. (December 1992) pg 905-915

Herman, Judith. Trauma and Recovery: The Aftermath of Violence from Domestic Abuse to Political Terror. New York: Basic Books, 1997. Print.

Hewitt, Daniel. 'Military Expenditures Worldwide: Determinants and Trends, 19721988.' Journal of Public Policy. Vol 12. No 2. (April-June 1992) pg 105-152

Hill, Catey. 'What PTSD Costs Families'. Marketwatch. April 4th, 2014. January 18th, 2015. < http://www.marketwatch.com/story/what-ptsd-costs-families-201404-04>.

Hobbes, Thomas. Leviathan. New York: Cosimo Books, 2009. Print.

Hodal, Kate. 'Thai King Endourses Army Chief as New Leader.' The Guardian. May 26th, 2014. January 31st, 2015.

$<$ http://www.theguardian.com/world/2014/may/26/thai-king-endorses-army-chiefleader- military-coup>.

Hoyt, Timothy. "Social Structure, Ethnicity and Military Effectiveness." Creating Military Power. Eds Brooks, Risa and Stanely, Elizabeth. Stanford: Stanford University Press. 2007.

Huebert, Rob. 'Renaissance in Canadian Arctic Security?' Canadian Military Journal. (Winter 2005-2006) pg 17-30

Huntington, Samuel. The Soldier and the State. Cambridge: Harvard University Press. 1957. Print.

Ignatieff, Michael. Blood and Belonging. Toronto: Penguin Canada. 1993. Print.

Irwin, Douglas. "The United States in a New Global Economy? A Century's

Perspective". The American Economic Review. Vol 86. No 2. (May 1996) pg 41-46

'Iqaluit.' The Canadian Encyclopedia. Nd. August 6th, 2012. Web. December 15th, 2014. 
Jacobsen, Annie. Operation Paperclip: The Secret Intelligence Program that Brought Nazi Scientists to America. New York: Little Brown. 2014. Print.

James, Andrew D. 'U.S. Defence R\&D Spending: An Analysis of the Impacts.' Prest, University of Manchester. (2004)

Jarecki, Eugene. The American Way of War. Toronto: Free Press. 2008. Print.

Jeffery, Terrance. 'Obama Increased Real Defence Spending by More than 10 Percent.' CNSnews.com. November 15th, 2012. < http://cnsnews.com/news/article/obamaincreased-real-defense-spending-more-10-percent $>$. November 24th, 2013

Jockel, Joe and Sokolsky Joel. 'Lloyd Axworthy's Legacy: Human Security and the Rescue of Canadian Defence Policy'. Canadian International Council. Vol 56. No 1. $2000 / 2001$ pg 1-18

Junger, Sebastian. War. New York: Twelve. 2011. Print.

Kagan, Donald. On the Origins of War: And the Preservation of Peace. New York: Double Day Books, 1995. Print.

Kaldor, Mary. “The Baroque Arsenal.” Ann Arbor: Andre Deutsch. 1982.

Kaldor, Mary. "Forward." In. Pianta, Mario. "New Technologies Across the Atlantic: U.S. Leadership or European Autonomy?" The United Nations University. Tokyo: Harvester Wheatsheaf. 1988.

Kane, Tim. 'Why Our Best Officers are Leaving'. The Atlantic. January 4, 2011. < http://www.theatlantic.com/magazine/archive/2011/01/why-our-best-officers-areleaving/308346/>. March 14th, 2015

Kennedy, Paul. The Rise and Fall of Great Powers. New York: Random House. 1989. Print.

Kessler, Glenn. 'President Obama and the Defence Budget'. The Washington Post. February 14th, 2012.< http://www.washingtonpost.com/blogs/factchecker/post/presidentobama-and-thedefense-budget/2012/02/13/gIQAoZXeCR blog.html>. November 23rd, 2013.

Kirshner, Jonathan. Appeasing Bankers: Financial Caution and the Road to War. Princeton: Princeton University Press, 2007. Print.

Knight, Malcolm et al. "The Peace Dividend: Military Spending Cuts and Economic Growth." The World Bank - International Monetary Fund. February 1996.

Krebs, Ronald. 'One Nation Under Arms? Military Participation and the Politics of 
Identity'. Security Studies. Vol 14 No. 3. Spring 2005

Lea, David. 'The new state-of-the-art Oakville Trafalgar Hospital will cost $\$ 2.7$ billion.' The IFP News. April 2nd, 2014. < http://m.theifp.ca/news-story/5372149-the-newstate- of-the-art-oakville-trafalgar-hospital-will-cost-2-7-bi/> .

Lenin, Vladimir. "Imperialism: The Highest Stage of Capitalism.” Marxists Internet Archive, 2008. Online. $<$ http://www.marxists.org/archive/lenin/works/1916/imp- hsc/ch05.htm>.

Lev-Wiesel, R and Amir, M. 'Secondary Traumatic Stress, Psychological Distress, Sharing of Traumatic Reminiscences, and Martial Quality Among Spouses of Holocaust Survivors'. Journal of Marital Family Therapy. Vol. 27 No. 4. October 2001. pg 433444

Locke, John. Two Treaties of Government. Cambridge, Cambridge University Press. 1988. Print.

Lyngaas, Sean. 'For Army Cyber, it's on-the-job training'. FCW. November 21st, 2014. January 17 th, 2015. < http://fcw.com/articles/2014/11/21/army-cyber.aspx $>$.

Mangum, Steven and Ball, David. "Military Skill Training: Some Evidence of Transferability." Armed Forces and Society. Vol 13. No 3. (Spring 1987.)

Mansfield, Edwin. "Technology and Productivity in the United States." The American Economy in Transition. Ed Feldstien, Martin. Chicago: University of Chicago Press, 1980.

Marshall, S.L.A. Men Against Fire: The Problem of Battle Command. New York: William Morrow. 1947. Print.

Marquis, Susan and Kirby, Sheila Nataraj. "Reserve Accessions Among Individuals with Prior Military Service: Supply and Skill Match.” Rand Corporation. October 1989.

Marx, Karl and Engels, Fredrick. "The Manifesto of the Communist Party." Marxists Internet Archive, 2010. Online < http://www.marxists.org/archive/marx/works/download/pdf/Manifesto.pdfs $>$.

Mastroeni, Michele. "Finance for high-tech sectors: state-led support for start-ups and spin-offs." International Journal of Entrepreneurship and Management. Vol 14, No. 2 (2011) 1741-5098

McCanles, Micheal. "Machiavelli and the Paradoxes of Deterrence." Diacritics. Vol 14 No 2. (Summer 1984)

McGrath, John. The Other End of the Spear: The Tooth-to-Tail (T3R) in Modern Military Operations. Fort Leavensworth, Kansas: Combat Studies Institute Press. 2007. Print. 
McKenna, R. "Technology and Freedom.” Paper for the Conference of Business Executives for National Security. January 29th, 1986.

"McKinsey on Government: Special Issue on Defence". McKinsey and Company. No. 5. Spring 2010.<

http://www.mckinsey.com/client_service/public_sector/latest_thinking/mckinsey_on_g overnment/defense $>$.

Molas-Gallart, Jordi, Military Production and Innovation in Spain. Philadelphia:

Harwood Academic Publishers. 1992. Print.

Myint-U, Thant. Where China Meets India: Burma and the New Crossroads of Asia. New York: Faber and Faber. 2011

Nelson, Richard. High Technology Policies: A Five-Nations Comparison. Washington D.C.: American Enterprise Institute. 1984.

Nelson, Richard. "National Innovation Systems: A Retrospective on a Study." Industrial and Corporate Change. Vol 1. No 2. 1992.

'Obama-Causus4Priorities' BarackObamadotcom.Youtube. October 22nd 2007. Flash video. $<$ http://www.youtube.com/watch?v=7084PE871BE $>$.

Offenhauer, Priscilla. 'Israel's Technology Sector.' Federal Research Division of the Library of Congress. Washington: November 2008.

O'Hanlon, Michael. The Science of War. Princeton: Princeton University Press. 2009. Print.

Orwell, George. 'You and the Atomic Bomb.' London: Tribune. October 19th, 1945.

Palme, Olof, et al. "Military Spending: The Economic and Social Consequences". Challenge. Vol. 25, No. 4, (1982): 4-21.

Perri, Timothy J. 'The Evolution of Military Conscription in the United States.' The Independent Review. Vol. 17 No. 3 (Winter 2013) pg 434-434

Pianta, Mario. "New Technologies Across the Atlantic: U.S. Leadership or European Autonomy?" The United Nations University. Tokyo: Harvester Wheatsheaf. 1988.

Piketty, Thomas. Capital in the Twenty-First Century. Cambridge: Harvard University Press. 2014. Print.

Polanyi, Karl. The Great Transformation. Boston: Beacon Press. 2001.

Punaro, Arnold et al. 'Reducing Overhead and Improving Business Operations: Initial Observations'. Defence Business Board. July 22, 2010. 
Reiter, Dan. "Nationalism and Military Effectiveness.” Creating Military Power. Eds Brooks, Risa and Stanely, Elizabeth. Stanford: Stanford University Press. 2007.

'Remarks by the President on the Defense Strategic Review.' The White House. January 5th, 2012. < http://www.whitehouse.gov/the-press-office/2012/01/05/remarks-presidentdefense-strategic-review $>$. November 24th, 2013.

Rosenburg, N. "Civilian 'Spillovers' from Military R and D Spending: The American Experience Since World War II.” Stanford University. 1986.

Rosenbush, Steve. 'The Demand for Cyber Security Jobs is Soaring.' The Wall Street Journal. March 4th, 2013. January 17th, 2015. <

http://blogs.wsj.com/cio/2013/03/04/demand-for-cyber-security-jobs-is-soaring/>.

Rosiello, Alessandro et al. 'Evolutionary policy targeting: towards a conceptual framework for effective policy intervention.' Technology Analysis and Strategic Management. Vol 25. No 7 (2013). 753-772

Rotemberg, Julio. 'Sticky Prices in the United States.' Journal of Political Economy. Vol 90. No 6. (December 1982) pg 1187-1211

Ruggie, John Gerard. "International Regimes, Transactions and Change: Embedded Liberalism in the Postwar Economic Order." International Organization. Vol 36. No 2. (Spring 1982)

Russett, Bruce. 'Who Pays for Defence?' The American Political Science Review. Vol 63. No 2. (June 1969) pg 412-426

Ruttan, Vernon. 'Is War Necessary for Economic Growth? Military Procurement and Technology Development.' Staff Paper. University of Minnesota. (October 2006) pg. 121

Ryall, Julian. 'Extends 10 Year Military Conscription.' The Telegraph. November 4th, 2014. January 18th, 2015. < http://www.telegraph.co.uk/news/worldnews/asia/northkorea/11207725/NorthKorea-extends-10-year-military-conscription.html>.

Saideman, Stephan. 'An Introduction to Civil-Military Relations.' Carleton University. River Building, Ottawa, Ontario. September 9th, 2013. Lecture

Satya, Paul. "Defence Spending and Unemployment Rates." Journal of Economic Studies. Vol. 23. No.2. (1996): 44-54.

Senor, Dan and Singer, Saul. Start-Up Nation: The Story of Israel's Economic Miracle. New York: Twelve. 2011. Print.

Shah, Anup. "World Military Spending." Global Issues. June 30th, 2013. < http://www.globalissues.org/article/75/world-military-spending $>$. November 15 th, 2013. 
Sloan, Elinor. The Revolution in Military Affairs. Montreal and Kingston: McGillQueen's University Press. 2002. Print.

Skidelsky, Robert. Keynes: A Very Short Introduction. New York: Oxford University Press. 2010. Print.

Smith, Adam. Wealth of Nations. New York: Bantam Books, 2003. Print.

Smith, Ron. Military Economics: The Interaction of Power and Money. New York: Palgrave MacMillan. 2011. Print.

Solomon, Henry. "Economic Issues in Cost-Effectiveness Analysis of Military Skill Training." Institute for Defence Analyses. March 1986.

Stepan, Alfred. The Military in Politics. Princeton: Princeton University Press. 1974. Print.

"Star 21 Strategic Aerospace Review for the 21st Century". European Commission. July 2002.

Statiev, Alexander. "When the Army Becomes 'Merely a Burden': Romanian Defence Policy and Strategy (1918-1941)" The Journal of Slavic Military Studies. Vol 13. No. 2 (June 2000)

"Subsidies through Government Procurement". Global Subsidies Initiative. International Institute for Sustainable Development. December 8th, 2014. < http://www.iisd.org/gsi/subsidy-types $>$.

Suvorov, Viktor. Soviet Military Intelligence. London: Grafton Books. 1986. Print.

Szymanski, Albert. 'Military Spending and Economic Stagnation.' American Journal of Sociology. Vol 79. No 1. (July 1973) pg 1-14

Taylor, John. "The Financial Crisis and the Policies Responses: An Analysis of What Went Wrong.” NBER Working Paper. No 14631. (January 2009) pg 1-30

Teslik, Lee Hudson. "Backgrounder: The U.S. Economic Stimulus Plan." The New York Times. January 27th, 2009. < http://www.nytimes.com/cfr/world/slot3 20090126.html?pagewanted=all\&_r=0 > . December 10th, 2013.

Tilly, Charles. "War Making and State Making as Organized Crime." Bringing the State Back In. Cambridge University Press. 1985. 169-186

Trebilcock, Clive. 'Spinoff' in British Economic History: Armaments and Industry 17601914.' The Economic History Review. Vol. 22 No. 3 1969. pg 474-490

Treddenick, John. 'The Arms Race and Military Keynesianism.' Canadian Public Policy. 
Vol 11. No 1. (March 1985) pg 77-92

TseTung, Mao. 'Problems of War and Strategy.' Selected Works. Vol 2. November 6th, 1938.

Twain, Mark. 'As Regards Patriotism.' A Pen Warmed Up in Hell: Mark Twain in Protest. (ed.) Anderson, Frederick. New York: Harper and Row Publishers. 1979.

Tyson, Ann Scott. 'Combat Stress May Cost up to \$6 Billion'. The Washington Post. April 18, 2008. January 18th, 2015. < http://www.washingtonpost.com/wpdyn/content/article/2008/04/17/AR2008041701749.html $>$.

Tzu, Sun. The Art of War. Puppet Press, 1910. Online. < http://www.puppetpress.com/classics/ArtofWarbySunTzu.pdf >. 46-48

Von Clausewitz, Carl. On War. New York: Oxford University Press. 2007. Print.

Walker, Dinah. "Trends in US Military Spending." Council on Foreign Relations. July 30th, $\quad 2013 . \quad<\quad$ http://www.cfr.org/defense-budget/trends-us-militaryspending/p28855>. November 25th, 2013.

Wallerstein, Immanuel. The Modern World System: Capitalist Agriculture and the Origins of the European World-Economy in the Sixteenth Century. New York:

Academic Press, 1976. Print.

Waltz, Kenneth. The Spread of Nuclear Weapons: More May be Better. London: International Institute for Strategic Studies. 1981. Print.

Ward, Michael and Davis, David. 'Sizing up the Peace Dividend: Economic Growth and Military Spending in the United States, 1946-1996.' The American Political Science Review. Vol 86. No 3. (September 1992) pg 748-755

Wolpin, Miles. "Comparative Perspectives on Militarization, Repression and Social Welfare". Journal of Peace Research. Vol. 20. No. 2. (1983): 129-155. 